\title{
Evaluation of phosphate solubilization from phosphoric rock via Aspergillus niger and Penicillium sp
}

\author{
Evaluación de solubilidad del fosfato de la roca fosfórica vía Aspergillus \\ niger y Penicillium sp
}

Leandro Argotte I. ${ }^{1}$; Oscar Fernando Barreiro Q. ${ }^{2}$; Néstor Enrique Cerquera P. ${ }^{3}$; Hans Thielin Castro S. ${ }^{4}$

\begin{tabular}{l}
\hline \multicolumn{2}{c}{ ARTICLE DATA } \\
\hline 1 Researcher, Chemical Engineer, Universidad \\
Surcolombiana, Neiva, Colombia, arkgox_1@ \\
hotmail.com \\
$2 \quad \begin{array}{l}\text { Researcher, Environmental Engineer, Universidad } \\
\text { Surcolombiana, Neiva, Colombia, barreiro. } \\
\text { oscar19@gmail.com }\end{array}$ \\
3 Researcher, M.Sc., Universidad Surcolombiana, \\
Neiva, Colombia, cerquera@usco.edu.co \\
4 Researcher, Ph.D. Corporación Universitaria del \\
Huila “CORHUILA", Neiva, Colombia, hsinsile@ \\
gmail.com
\end{tabular}

Cite: Argotte, L.; Barreiro, O.; Cerquera, N.; Castro, H. (2020). Evaluation of phosphate solubilization from phosphoric rock via Aspergillus niger and Penicillium sp. Revista de Ciencias Agrícolas. 37(2): 4-13.

doi: https://doi.org/10.22267/rcia.203702.133

Received: September 252020. Accepted: December 102020.

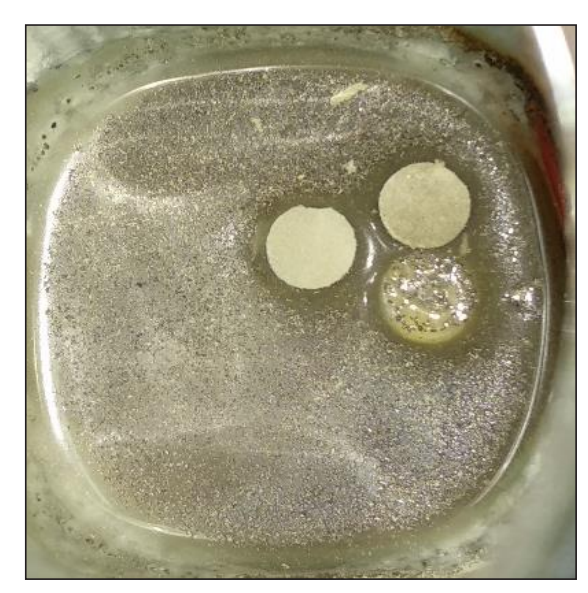

Ejemplo de cultivo de hongo Aspergillus en vinazas de café y roca fosfórica

\begin{abstract}
Phosphoric rock is the main source of phosphorus used in fertilizers. In most cases, it is applied alone or mixed with other nutrients in water; however, its low solubility means that it is not used efficiently, causing excess phosphorus to be wasted. As a result, it generates economic expenses to the farmer, or causing problems of eutrophication in water sources. In this article, different mixtures of solubilizing fungi with coffee pulp stillage were studied to improve phosphates' solubility in phosphate rock. Despite that in different studies is clear the fungi's role in P solubilization, its application on soils is still made without any additional treatment. Phosphoric rock samples were obtained from the municipality of Aipe (Huila) and were treated for 6 weeks with coffee pulp stillage (Coffea arabica) and inoculums of Aspergillus niger and Penicillium sp, $\mathrm{pH}$ and temperature controlled. The fungus species were obtained from environmental media on PDA culture, then it was isolated and identified on MEA culture according to standard morphologic identification methods. Aspergillus niger showed greater mycelial growth in the stillage and a higher concentration of phosphates dissolved in the aqueous phase $(72 \pm 31 \mathrm{M})$ compared to Penicillium sp. The mixture of the two fungi in the treatments allowed to obtain the highest percentage of phosphates $(17.8 \%$ of the phosphate soluble in $\mathrm{H}_{2} \mathrm{SO}_{4} 40 \% \mathrm{v} / \mathrm{v}$ ).
\end{abstract}

Key words: sustainable agriculture; land resources; liquid fertilizers; Phosphate solubilizing microorganisms; fungi.

\section{RESUMEN}

La roca fosfórica es la principal fuente de fósforo usada en los fertilizantes. En la mayoría de los casos, se aplica sola o mezclada con otros nutrientes en agua; sin embargo, su baja solubilidad no permite su total aprovechamiento, haciendo que el exceso de fósforo se desaproveche, genere gastos económicos para al agricultor o produzca problemas de eutrofización en fuentes de agua. En este artículo se estudiaron diferentes mezclas de hongos solubilizadores (MSP) con vinaza de pulpa de café para mejorar la solubilidad de los fosfatos de la roca fosfórica, ya que a pesar de que en diferentes estudios se ha 
evidenciado su rol en la solubilización de P, su aplicación en suelos se sigue haciendo sin ningún tratamiento adicional. Las muestras de roca fosfórica fueron obtenidas del municipio de Aipe (Huila) y se trataron durante seis semanas con vinazas de pulpa de café (Coffea arábiga L.) e inóculos de Aspergillus niger y Penicillium sp, pH y temperatura controlados. Los hongos fueron obtenidos en Agar Papa Dextrosa (PDA), y aislados e identificados en Agar Extracto de Malta (MEA) de acuerdo con métodos estándar de identificación morfológica. El Aspergillus niger mostró mayor crecimiento micelial en las vinazas y obtuvo una mayor concentración de fosfatos disueltos en fase acuosa $(72 \pm 31 \mathrm{M})$ en comparación con Penicillium $s p$. La mezcla de los dos hongos en los tratamientos permitió obtener el mayor porcentaje de fosfatos $(17,8 \%$ del fosfato soluble en $\mathrm{H}_{2} \mathrm{SO}_{4} 40 \% \mathrm{v} / \mathrm{v}$ ).

Palabras clave: Agricultura sostenible; recurso suelo; fertilizantes líquidos, microorganismos solubilizadores de fosfatos; hongos.

\section{INTRODUCTION}

Agriculture consumes large amounts of phosphorus for soil fertilization using phosphate rock extracted from deposits. According to the 2017 reports from the USGS (United States Geological Surveys) (USGS, 2017) and the FAO (Zapata and Roy, 2007), it is estimated that in about 50 years, between 2040 and 2060, the conventional sources of phosphate rock (PR) will begin to be scarce. As well in about 100 years, the mines with easy access to this mineral would be exhausted (Gilbert, 2009).

Thus, promoting the exploitation of less profitable mines (Restrepo et al., 2015). However, current fertilization practices that have a phosphorus application efficiency of less than 30\% (Goldstein et al., 1993) could affect a possible crisis scenario in agricultural production (Cordell, 2010; Cordell et al., 2009; Walan et al. 2014; Edixhoven et al., 2013).

Microorganisms secrete various metabolites within their metabolic cycle as organic acids capable of solubilizing phosphorus from insoluble forms of phosphorus minerals as PR (Rashid et al., 2004). These acids (D-malic, D-lactic, L-malic, L-lactic, acetic, citric, oxalic, gluconic, Iyyappan et al., 2018; Li et al., 2015) act as ligands of sequestering cations bound to phosphate groups in a mechanism called chelation.

In fact, these acid metabolites play determining roles in the rhizosphere dynamics and jointly influence the solubilization of phosphates from soil minerals (Wakelin etal., 2004). The fungi Aspergillus niger and Penicillium Sp are potentially usable as phosphate solubilizing microorganisms (PSM) on an agro-industrial scale (Yin et al., 2015; Mendes et al., 2015) because these fungi are practically ubiquitous species in the natural environment, and they are characteristic of Colombian soils (Pérez et al., 2012). However, there is a great variety of species around the world.

In addition, these fungi have the ability to withstand environmental conditions and difficult substrates for other species, which implies that they have adaptive mechanisms to feed on unconventional sources of nutrients, and they generate specialized substances capable of carrying out these metabolic processes (Kaur and Reddy, 2017). For example, studies of deficient phosphorus soils (as Amazon basin soils and moor's acid soils) several phosphorussolubilizing microorganisms, that have allowed the conservation of biota have been isolated (Vera et al., 2002; Lizarazo and Vásquez, 2015).

A well-studied reaction scheme in the solubilization of phosphate, using microorganisms via the formation of metal complexes of $\mathrm{Ca}^{+2}$, is presented in equations 1 and 2 (Ivanova et al., 2006). In these reactions, $\mathrm{Ca}^{+2}$ is presented as a main component of apatites (or phosphoric rocks), and organic acids such as oxalic acid and citric acid that form calcium oxalate and calcium citrate, respectively. These acids are common metabolites produced by species of the fungi Penicillium sp and Aspergillus niger (Visagie et al., 2014) and are recognized as PSM (Posso and De Prager, 2017). 


$$
\begin{aligned}
& \underbrace{2 \mathrm{Ca} \mathrm{F}_{4}\left(\mathrm{PO}_{4}\right)_{3}}_{\text {insoluble }}+\underbrace{20(\mathrm{HX})}_{\text {soluble }} \rightarrow \underbrace{10 \mathrm{CaX}}_{\text {insoluble }}+\underbrace{6 \mathrm{H}_{3} \mathrm{PO}_{4}}_{\text {soluble }}+\underbrace{2 \mathrm{HF}}_{\text {soluble }} \quad \text { Eq.1 } \\
& \underbrace{2 \mathrm{Ca} \mathrm{F}_{5}\left(\mathrm{PO}_{4}\right)_{3}}_{\text {insoluble }}+\underbrace{14(\mathrm{HX})}_{\text {soluble }} \rightarrow \underbrace{7 \mathrm{CaX} \mathrm{X}_{2}}_{\text {insoluble }}+\underbrace{3 \mathrm{Ca}\left(\mathrm{H}_{2} \mathrm{PO}_{4}\right)_{2}}_{\text {soluble }}+\underbrace{2 \mathrm{HF}}_{\text {insoluble }} \quad \text { Eq.2 }
\end{aligned}
$$

Where XH can be citric ( ) or oxalic acid 0

Equations 1 and 2 show the organic acid's action in forming poorly soluble compounds namely as calcium chelates, $\mathrm{CaX}_{2}$, and soluble compounds; calcium diphosphate as an intermediate product (superphosphate) and phosphoric acid $\left(\mathrm{H}_{3} \mathrm{PO}_{4}\right)$. In these processes, the phosphateionis releasedfrom the solid substrate by the chelating action of citric or oxalic acids on the $\mathrm{Ca}^{+2}$ cation (Mai et al., 2016). The power of complex-forming acids (chelates) consists in the action of oxygens (more electronegative) of the carboxyl groups that surround the calcium cation (Harvey, 2000). In this way, they can solubilize insoluble compounds as found in apatite.

The global trend is oriented towards scientific advancement for the development of innovative technologies that make agribusiness sustainable (Zapata and Roy, 2007), and the use of microorganisms to improve the solubility of phosphates in phosphate rock has been suggested in different works (Restrepo et al., 2015; Stutter et al., 2012; Li et al., 2015). For this reason, there are different advances in soil bioremediation (Pineda, 2015) and in biofertilization (Pérez et al., 2012).

Therefore, the Aspergillus niger and Penicillium $s p$ species were used in the formulation, application and evaluation of treatments that allow solubilizing phosphates from phosphate rock samples taken from the Media Luna mine in Aipe- Huila (Colombia), one of the places where phosphate rock is extracted.

\section{MATERIALS AND METHODS}

Phosphoric Rock. The ground phosphoric rock samples were collected from the Media Luna mine in Aipe, Huila, with coordinates: Latitude $3^{\circ} 54^{\prime} 0.50184^{\prime \prime} \mathrm{N}$, Longitude $75^{\circ} 19^{\prime} 32.0592^{\prime \prime}, 20 \mathrm{~km}$ from the municipal seat. The samples were sieved in the laboratory and the fractions with particle

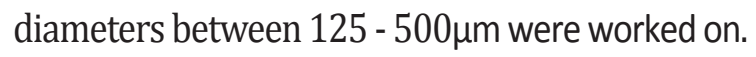

Coffee pulp substrate (stillage). The biological treatment was carried out in an aqueous medium, with aeration, and coffee pulp (Coffea arabiga) was used as substrate; material selected for its content of carbohydrates and essential nutrients (Silva et al., 2013; Serrat et al., 2018) due to the recognized problem as a residue in coffee production (Beyene et al, 2012). Fresh coffee pulp from the rural area of San Agustín was obtained with coordinates: Latitude $1^{\circ} 54^{\prime} 05.9760^{\prime \prime} \mathrm{N}$, Longitude: $75^{\circ} 17^{\prime} 06.9828^{\prime \prime} \mathrm{W}$.

The coffee pulp was collected from the coffee pulping process, part of the coffee mill in which the pulp is generally discarded as waste. Later, the coffee pulp was stored under refrigeration and transferred to laboratory. In laboratory, the pulps were macerated with distilled water, filtered, sterilized in an autoclave (model N075X) for $20 \mathrm{~min}$ at $120^{\circ} \mathrm{C}$ and $1.0 \mathrm{MPa}$. 
No additional nutrient was added. This preparation will be referred to as vinasse due to its richness in fermentable sugars and its easy biodegradation by microorganisms. The $\mathrm{pH}$ measured in the stillage was 4.0 , which was not modified to sow of the inocula.

\section{Colonies of Aspergillus niger and Penicillium} sp. $20 \mathrm{~mL}$ of PDA (Potato Dextrose Agar) were poured into $90 \mathrm{~mm}$ Petri dishes. The boxes were then exposed to the environment for 30 minutes to collect the microorganisms presented. The mushrooms's capture was made in the urban area of Neiva-Huila with coordinates $\left(2^{\circ} 55^{\prime} 50.85^{\prime \prime} \mathrm{N}\right.$, $75^{\circ} 15^{\prime} 54.503^{\prime \prime} \mathrm{W}$ ), with a warm tropical climate and average daytime temperatures of $28^{\circ} \mathrm{C}$.

Then, the Petri dishes were sealed and incubated in the dark for 7 days at an average temperature of $29^{\circ} \mathrm{C}$. After this time, the Petri dishes were selected in which, possible colonies of Aspergillus niger and Penicillium sp were identified according to the Visagie (2014) methodology by observing their macroscopic characteristics. Then, under aseptic conditions with a controlled environment in a laminar flow cabinet, colonies of individual species were sown from the cultures previously obtained and identified in Malt Extract Agar
(MEA). Finally, the macroscopic and microscopic identification of the species was made using an Olympus model microscope by comparing their morphological characteristics, observing the outcrop of conidiophores, and the formation of hyphae inoculated fungi.

Evaluation of the treatments with stillage, Aspergillus niger, and Penicillium sp. The applied treatments V, VA, VP, VAP, and H40 are described in Table 1 for a $2 \times 2$ factorial design, for a total of 15 experimental units where the composition of the treatment was varied in a controlled temperature of $30.6^{\circ} \mathrm{C}$. The variable evaluated was the composition of the mixture, conserving the proportions of RF and stillage used, but changing the mass ratio of the fungi, and the observable was the dissolved phosphate for several days of incubation.

The change in $\mathrm{pH}$ was controlled with the addition of $\mathrm{CaCO}_{3}$ and all experiments were done by triplicate. In the treatments, the coffee pulp (Coffea arabiga) was used as a substrate due to its easy obtaining as a by-product in the Coffee production (Puerta and Ríos, 2014; Serrat et al., 2018). The treatments were carried out in a controlled environment (Figure 1) with aeration during intervals of two hours per day.

Table 1. Description of the biological treatments used for the solubilization of phosphorus.

\begin{tabular}{cclc}
\hline No. & Treatment (B) & \multicolumn{1}{c}{ Descripción } & $\begin{array}{c}\text { Mass ratio of Aspergillus } \\
\text { niger: Penicillium sp. }\end{array}$ \\
\hline 1 & $V$ & PR + stillage & $(0: 0)$ \\
2 & $V A$ & PR + stillage + Aspergillus niger & $(1: 0)$ \\
3 & $V P$ & PR + stillage + Penicillium sp. & $(0: 1)$ \\
4 & $V A P$ & PR + stillage+ Penicillium sp. + Aspergillus niger & $(1: 1)$ \\
5 & $H 40^{*}$ & PR+ (Reference) & ---- \\
\hline
\end{tabular}

* Biological treatment. 
a.

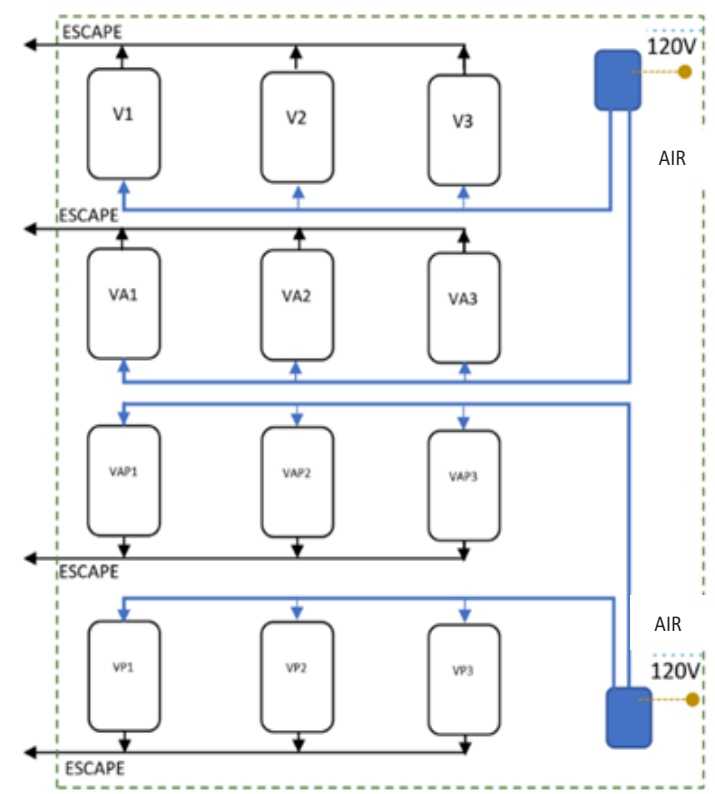

b.

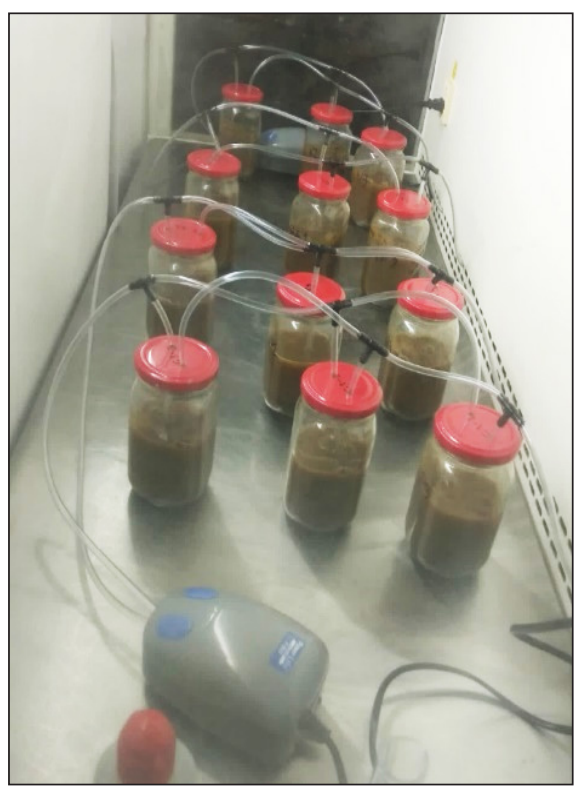

Figure 1. Configuration of the treatment aeration system a) Scheme b) Photograph of an aeration system.

Dissolved phosphate was determined by colorimetry. $7 \mathrm{~mL}$ samples were taken. They were centrifuged for $30 \mathrm{~min}$ at 5000rpm to eliminate the high turbidity and the solids particles. Then, $5 \mathrm{~mL}$ aliquots were taken and diluted to $50 \mathrm{~mL}$ with distilled water. These solutions were treated with aluminum sulfate crystals to remove the color caused by the biological remnant and were centrifuged for 15 min to remove the flocs formed.

Finally, $10 \mathrm{~mL}$ of the clarified solution was mixed with $2.5 \mathrm{~mL}$ of vanadate-molybdate reagent (RVM), and the absorbance at $400 \mathrm{~nm}$ wavelength was measured in a SPECTROQUANT model PHARO 300 spectrophotometer.

The results were correlated with the curve of monopotassium phosphate standards, previously prepared and valid for a range of 0 to $50 \mathrm{ppm}$ of phosphate in the aqueous phase.

Data analysis. The Bartlett test was performed to establish the normality of the data $(p>0.05)$ checking the assumptions of normality and homoscedasticity, and performing an analysis of variance by ranges for non-parametric distributions with the Kruskal-Wallis test. The null hypothesis was evaluated (for each case of interest) with a significance level of 5\%. Matlab R2016a, Inc. software was used for statistical analysis (Mathworks, 2019a; Mathworks, 2019b; Mathworks, 2019c; Mathworks, 2019d).

\section{RESULTS AND DISCUSSION}

Table 2 shows the percentage of total dissolved phosphorus achieved with the treatments and $\mathrm{H}_{2} \mathrm{SO}_{4}(40 \% \mathrm{v} / \mathrm{v})$. The V, VA, VP, and VAP treatments were positive in the phosphate dissolution of the phosphate rock, the VAP treatment being the most prominent, $7.8 \%$ of the phosphorus solution obtained with $\mathrm{H}_{2} \mathrm{SO}_{4} \quad(40 \% \quad \mathrm{v} / \mathrm{v})$. All treatments showed significant differences among themselves for 42 days of incubation. 
Table 2. Dissolved $\mathrm{PO}_{4}$ values obtained for each biological treatment for 42 days of incubation at $30^{\circ} \mathrm{C}$.

\begin{tabular}{cllcc}
\hline No. & Treatment & \multicolumn{1}{c}{ Descripción } & $\mathbf{P O}_{4}$ dissolved (\%) & $\frac{\mathbf{P}_{\mathbf{t}}}{\mathbf{P}_{\mathrm{H} 40}} \times \mathbf{1 0 0}^{*}(\%)$ \\
\hline 1 & $V^{*}$ & PR + stillage & $0,15 \pm 0,01$ & 2,4 \\
2 & $V A^{*}$ & PR + stillage + Aspergillus niger & $0,33 \pm 0,03$ & 5,3 \\
3 & $V P^{*}$ & PR + stillage + Penicillium sp. & $0,19 \pm 0,01$ & 2,9 \\
4 & $V A P^{*}$ & PR + stillage + Penicillium sp. + Aspergillus niger & $1,13 \pm 0,03$ & 17,8 \\
5 & $\mathrm{H}_{2} \mathrm{SO}_{4} 40 \%$ & PR+ (Authors) & $6,34 \pm 0,10$ & 100 \\
\hline
\end{tabular}

${ }^{*} \mathrm{x} \pm \sigma,(\mathrm{n}=5)$

Whereas the dissolved phosphate concentrations (Table 3) for the VA and VAP treatments increased significantly as the incubation days passed, the phosphorus concentrations with the $\mathrm{V}$ and $\mathrm{VP}$ treatments decreased from the first week of incubation. The highest phosphate concentration was for the VAP treatment $(140 \pm 17.1 \mathrm{mg} / \mathrm{L})$ and the lowest concentration was with the $V$ treatment $(13 \pm 1.5 \mathrm{mg} / \mathrm{L})$.

Table 3. Average concentrations of soluble P $(\mathrm{mg} / \mathrm{mL})$ for each of the biological treatments according to the days of incubation.

\begin{tabular}{ccccccc}
\hline \multirow{2}{*}{ Treatments } & \multicolumn{5}{c}{ Concentration of P (mg/mL)/Days of incubation* } \\
\cline { 2 - 7 } & $\mathbf{0}$ & $\mathbf{5}$ & $\mathbf{1 2}$ & $\mathbf{1 8}$ & $\mathbf{2 5}$ & $\mathbf{3 1}$ \\
\hline V & $28 \pm 0,9$ & $19 \pm 12,9$ & $16 \pm 2,6$ & $13 \pm 1,5$ & $18 \pm 3,0$ & $19 \pm 4,8$ \\
VA & $23 \pm 1,8$ & $29 \pm 3,4$ & $47 \pm 7,0$ & $41 \pm 4,7$ & $34 \pm 1,0$ & $35 \pm 2,5$ \\
VP & $26 \pm 2,0$ & $22 \pm 6,1$ & $25 \pm 2,7$ & $21 \pm 3,3$ & $19 \pm 2,6$ & $18 \pm 1,6$ \\
VAP & $31 \pm 5,1$ & $103 \pm 31,6$ & $127 \pm 21,2$ & $140 \pm 17,1$ & $134 \pm 25,0$ & $127 \pm 17,2$ \\
\hline
\end{tabular}

$*_{n}=5, \mathrm{x} \pm \sigma$

The phosphate concentrations are similar to other values $(201.3-283.7 \mathrm{mg} / \mathrm{L})$ reported in similar works (Chunquiao et al., 2015) with solubilizing fungi e.g Aspergillus niger and Aspergillus carbonarius. The authors incorporated ammonium and nitrate to the culture medium as additional nutrients or to the soluble phosphate concentrations (284.7 - $366.6 \mathrm{mg} / \mathrm{L})$ reported in a work carried out with the genetically modified Aspergillus niger fungus (Cássia et al., 2014).

Significant differences were found between the data groups of each treatment for each week of study with a significance level of 0.05 , applying the Kruskal-Wallis test (Table 4). 
Table 4. Kruskal -Wallis hypothesis test for a significance level of 0.05 for the treatments during different days of incubation.

\begin{tabular}{cll}
\hline Caso & \multicolumn{1}{c}{ Assumed hypothesis } & \multicolumn{1}{c}{$\mathbf{H}<\boldsymbol{X}^{2}$} \\
\hline i. & $\mathrm{H}_{\mathrm{a}}$ : There is a significant difference in $\mathrm{PO}_{4}^{-3}$ concentration between different treatments for day 1. & $0,119<5,87$ \\
ii. & $\mathrm{H}_{\mathrm{a}}$ : There is a significant difference in $\mathrm{PO}_{4}^{-3}$ concentration between different treatments by day 5. & $0,0415<8,23$ \\
iii. & $\mathrm{H}_{\mathrm{o}}$ : There is a significant difference ${\mathrm{in} \mathrm{PO}_{4}^{-3} \text { concentration between different treatments by day 12. }}^{-3}$ & $0,01530<10,42$ \\
iv. & $\mathrm{H}_{\mathrm{o}}$ : There is a significant difference in $\mathrm{PO}_{4}^{-3}$ concentration between different treatments by day 18. & $0,01560<10,38$ \\
v. & $\mathrm{H}_{\mathrm{a}}$ : There is a significant difference in $\mathrm{PO}_{4}^{-3}$ concentration between different treatments by day 25. & $0,0227<9,56$ \\
vi. & $\mathrm{H}_{\mathrm{a}}$ : There is a significant difference in $\mathrm{PO}_{4}^{-3}$ concentration between different treatments by day 31. & $0,0230<9,53$ \\
\hline
\end{tabular}

The increase of the micellar diameter was a result of the fungi's growth. Aeration allowed constant mixing which contributed to abundant hyphal growth and sporulation in the second week. In all treatments, the formation of supernatant gelatinous masses, or also submerged in the substrate, was observed mainly composed of mycelia of fungi and organic matter. In some treatments, changes are observed in the color of the liquid phase, which turned dark. In addition, samples of the treatments were periodically observed under the microscope, and the presence of inoculated fungi was verified.

In the VP treatment, there was little growth of Penicillium sp colonies, in the form of thin superficial films (approx. $1 \mathrm{~mm}$ ) that showed slight sporulation. In VA, there was a growth of Aspergillus niger colonies, in the form of superficial films $(1-2 \mathrm{~mm})$, and abundant sporulation with a darker coloration. In VAP, the majority growth of Aspergillus niger colonies (over those of Penicillium sp), was observed covering almost the entire surface in the form of superficial films of great thickness $(10-30 \mathrm{~mm})$ with abundant sporulation and with small islands of colonies of Penicillium sp; also, sporulated (less than $10 \mathrm{~mm}$ in diameter). On a microscopic scale, the growth of the characteristic conidiophores inoculated in VA, VP, and VAP was periodically observed, as well as the gelatinous films formed in which an abundant growth of hyphae was identified.
The metabolism the Aspergillus niger and Pencillium sp. fungus excretes organic acids. The increase in $\mathrm{pH}$ can be explained by different causes including the dissolution of carbonates and / or hydroxyl present in RF. There is also the probability that there was ammonia production because of the unwanted presence of bacteria (Beyenne et al., 2012; Peterson et al., 2005).

According to the results, it can be inferred that Aspergillus niger presented a better adaptation to the substrate in the process conditions than Penicilium sp. Interestingly. The highest dissolution values were reached in the combined VAP treatment, which may a possible synergistic activity between the two species. Nevertheless, the predominant advance of Aspergillus niger was evidenced macroscopically. An interesting feature in the tests where Aspergillus niger thrived was the black staining of the aqueous phase, possibly due to the high production of spores; this characteristic coincided with a higher dissolution of phosphates. Finally, it was found that these are a suitable medium for the growth of the fungi Aspergillus niger and Penicillium sp concerning stillage; following what is suggested by other authors (Ivanova et $a l, 2006)$, even at low $\mathrm{pH}$ values. 


\section{CONCLUSIONS}

All the biological treatments applied in this study contributed to the solubilization of phosphates in phosphate rock with significant differences between them. The treatment that included the mixture of fungi Aspergillus niger - Penicillium $s p$ reached the highest concentration of soluble phosphate (1.13 \pm 0.03 ), achieving $17.8 \%$ of the solution obtained with concentrated sulfuric acid $\left(\mathrm{H}_{2} \mathrm{SO}_{4}-40 \%\right)$.

\section{ACKNOWLEDGMENT}

The authors thank FOSFATOS DEL HUILA for providing the samples for this project.

Conflict of interests: The authors declare thatthere is no conflict of interest.

\section{REFERENCIAS BIBLIOGRÁFICAS}

Beyene, A.; Kassahun, Y.; Addis, T.; Assefa, F.; Amsalu, A.; Legesse, W.; Triest, L.; (2012). The impact of traditional coffee processing on river water quality in Ethiopia and the urgency of adopting sound environmental practices. Environ. Monit. Assess. 184(11): 7053-7063. doi: http://dx.doi. org/10.1007/s10661-011-2479-7

Cássia, U.; Oliveira, G.; Morena, N.; Leal, J.; Ribeiro, I.; Rogério, M.; Dutra, M. (2014). Fluoride-tolerant mutants of Aspergillus niger show enhanced phosphate solubilization capacity. PLOS ONE. 9(10): 1-9. doi: http://dx.doi.org/10.1371/journal. pone. 0110246

Chunquiao, X.; Fang, Y.; Chi, R. (2015). Phosphate solubilization in vitro by isolated Aspergillus niger and Aspergillus carbonarius. Res. Chem. Intermed. 41(5): 2867 -2878. doi: http://dx.doi.org/10.1007/ s11164-013-1395-6

Cordell, D. (2010). The Story of Phosphorus: Sustainability implications of global phosphorus scarcity for food security (Doctoral dissertation). Sydney: University of Technology Sydney. 139p.
Cordell, D.; Drangert, J. 0.; White, S. (2009). The story of phosphorus: global food security and food for thought. Global Environ. Chang. 19(2): 292-305. doi: http://dx.doi.org/10.1016/j. gloenvcha.2008.10.009

Edixhoven, J. D.; Gupta, J.; Savenije, H. H. G. (2013). Recent revisions of phosphate rock reserves and resources: reassuring or misleading? An in-depth literature review of global estimates of phosphate rock reserves and resources. Earth Syst. Dynam. Discuss. 4 (2):1005-1034. doi: http://dx.doi. org/10.5194/esdd-4-1005-2013

Gilbert, N. (2009). Environment: the disappearing nutrient. Nature News. 461(7265): 716-718. doi: http://dx.doi.org/10.1038/461716a

Goldstein, A. H.; Rogers; R. D., Mead; G. (1993). Mining by microbe. Bio. Technol. 11: 1250-1254.

Harvey, D. (2000). Modern Analytical Chemistry. Boston: McGraw-Hill Companies, Inc.

Ivanova, R. P.; Bojinova, D.Y.; Gruncharov, I. N.; Damgaliev, D. L. (2006). The solubilization of rock phosphate by organic acids. Phosphorus Sulfur. 181(11): 2541-2554. doi: http://dx.doi. org/10.1080/10426500600758399

Iyyappan,J.; Bharathiraja, B.; Baskar, G.; Jayamuthunagai, J.; Barathkumar, S. (2018). Malic acid production by chemically induced Aspergillus niger MTCC 281 mutant from crude glycerol. Bioresour. Technol. 251: 264-267. doi: http://dx.doi.org/10.1016/j. biortech.2017.12.055

Kaur, G.; Reddy, M. S. (2017). Improvement of crop yield by phosphate-solubilizing Aspergilluss species in organic farming. Arch. Agron. Soil Sci. 63 (1):24-34. doi: http://dx.doi.org/10.1080/03650340.2016.11 82161

Li, H.; Liu, J.; Li, G.; Shen, J.; Bergstrom, L.; Zhang, F. (2015). Past, present, and future use of phosphorus in Chinese agriculture and its influence on phosphorus losses. Ambio. 44 (2): 274-285. doi: http://dx.doi.org/10.1007/s13280-015-0633-0

Lizarazo, P. X.; Gómez, D. (2015). Microbiota rizosférica de Espeletia spp. de los páramos de Santa Inés y de Frontino-Urrao en Antioquia - Colombia. Acta Biol. Col, 20 (1): 175-182. doi: http://dx.doi. org/10.15446/abc.v20n1.42827. 
Mai, H. T. N.; Lee, K. M.; Choi, S.S. (2016). Enhanced oxalic acid production from corncob by a methanolresistant strain of Aspergillus niger using semi solidsate fermentation. Process Biochem. 51 (1): 9-15. doi: http://dx.doi.org/10.1016/j.procbio.2015.11.005

Mathworks. (2019a). Kruskal-Wallis test - MATLAB kruskalwallis. Recovered from https://www. mathworks.com/help/stats/kruskalwallis. html\#btv4oqy-6

Mathworks. (2019b). Multiple comparison test MATLAB multcompare. Recovered from https:// www.mathworks.com/help/stats/multcompare. html? searchHighlight=multcompare\&s_tid=doc_ srchtitle

Mathworks. (2019c). Multiple-sample tests for equal variances - MATLAB vartestn. Recovered from https://www.mathworks.com/help/stats/vartestn. html\#btuo1pv

Mathworks. (2019d). One-way analysis of variance MATLAB anova1. Recovered from https://www. mathworks.com/help/stats/anova1.html

Mendes, G. D. 0.; da Silva, N. M. R.M.; Anastácio, T. C.; Vassilev, N. B.; Ribeiro Jr, J. I.; da Silva, I. R.; Costa, M. D. (2015). Optimization of Aspergillus niger rock phosphate solubilization in solid-state fermentation and use of the resulting product as a $\mathrm{P}$ fertilizer. Microbial Biotechnol. 8(6): 930-939.

Pérez, C, A.; de la Ossa, J.; Montes, V. D. (2012). Hongos Solubilizadores de Fosfatos en fincas ganaderas del departamento de Sucre. RECIA. 4(1): 35-45. doi: http://dx.doi.org/10.24188/recia.v4.n1.2012.263.

Peterson, S, W.; Vega, F. E.; Posada, F.; Nagai, C. (2005). Penicillium coffeae, a new endophytic species isolated from a coffee plant and its phylogenetic relationship to $P$, fellutanum, $P$. thiersii and $P$. brocae based on parsimony analysis of multilocus DNA sequences. Mycologia, 97(3): 659-666. doi: https:// doi.org/10.1080/15572536.2006.11832796

Pineda, M. B. (2015). Hongos solubilizadores de fosfato en suelo de páramo cultivado con papa [Solanum tuberosum]. Ciencia en Desarrollo. 5(2):145-154. doi: http://dx.doi.org/10.19053/01217488.3669

Posso, E. J. S.; de Prager, M. S. (2017). Production of organic acids by rhizosphere microorganisms isolated from a Typic Melanudands and its effects on the inorganic phosphates solubilization. Acta Agron. 66(2): 241 -247. doi: http://dx.doi.org/10.15446/ acag.v66n2.56148

Puerta, G.; Ríos, S. (2011). Composición Química del mucílago de café según el tiempo de fermentación y refrigeración. Cenicafe. 62 (2):23-40.

Rashid, M.; Khalil, S.; Ayub, N.; Alam, S.; Latif, f. (2004). Organic acids production and phosphate solubilization by phosphate solubilizing microorganisms (PSM) under in vitro conditions. Pak. J. Biol. Sci. 7 (2):187-196.

Restrepo G. M.; Marulanda, S.; de la Fe, Y.; Díaz, A.; Lucia, V.; Hernández, A. (2015). Bacterias solubilizadoras de fosfato y sus potencialidades de uso en la promoción del crecimiento de cultivos de importancia económica. CENIC. 46(1): 63 -76.

Serrat, M.; la Dé, D.; Daniel, Á.; la Fé, D.; Alberto, J.; Montero, C. (2018). Extracción y caracterización de pectina de pulpa de café de la variedad Robusta. Revista Cubana de Química. 30 (3):522-538.

Silva, C.F.; Vilela, D. M.; de Souza Cordeiro, C.; Duarte, W.F.; Dias, D.R.; Schwan, R.F. (2013). Evaluation of a potential starter culture for enhance quality of coffee fermentation. World J Microbiol Biotechnol. 29(2):235-47. doi: 10.1007/s11274-012-1175-2

Stutter, M. I.; Shand, C. A.; George, T. S.; Blackwell, M. S. A.; Bol, R.; Mackay, R. L.; Haygarth, P. M. (2012). Recovering phosphorus from soil: A root solution? Environ. Sci. Technol. 46(4): 1977-1978. doi: http:// dx.doi.org/10.1021/es2044745

USGS - United States Geological Survey. (2017). Mineral commodity summaries 2017. Reston, VA U.S: Geological Survey, 202 p. doi: https://doi. org/10.3133/70180197

Vera, D. F.; Pérez, H.; Valencia, H. (2002). Aislamiento de hongos solubilizadores de fosfatos de la rizósfera de Arazá (Eugenia stipitata, Myrtaceae). Acta Biol. Col. 7(1): 33-40. doi: http://dx.doi.org/10.15446/abc

Visagie, C. M.; Houbraken, J.; Frisvad, J. C.; Hong, S. B.; Klaassen, C. H. W.; Perrone, G.; Samson, R.A. (2014). Identification and nomenclature of the genus Aspergilluss. Stud. Mycol. 78 (1): 343-371. doi: http://dx.doi.org/10.1016/j.simyco.2014.09.001 
Wakelin, S. A.; Warren, R. A.; Harvey, P.R.; Ryder, M. H. (2004). Phosphate solubilization by Penicillium $s p$, closely associated with wheat roots. Biol. Fert. Soils. 40(1): 36-43. doi: https://doi.org/10.1007/ s00374-004-0750-6

Walan, P.; Davidsson, S.; Johansson, S.; Höök, M. (2014). Phosphate rock production and depletion: Regional disaggregated modeling and global implications. Resour. Conserv. Recy. 93: 178-187. doi: http:// dx.doi.org/10.1016/j.resconrec.2014.10.011

Yin, Z.; Shi, F.; Jiang, H.; Roberts, D. P.; Chen, S.; Fan, B. (2015). Phosphate solubilization and promotion of maize growth by Penicillium oxalicum P4 and Aspergillus niger P85 in a calcareous soil. Can J. Microbiol. 61(12): 913-923. doi: https://doi. org/10.1139/cjm-2015-0358

Zapata, F.; Roy, R.N. (2007). Utilización de las rocas fosfóricas para una agricultura sostenible. Roma: Organización de las Naciones Unidas para la agricultura y la alimentación y del organismo internacional de Energía Atómica. 73p. 


\title{
Biofertilizer potential of digestates from small-scale biogas plants in the Cuban context
}

\author{
Potencial biofertilizante del digestato obtenido en plantas de biogás a pequeña \\ escala en el contexto cubano.
}

Leyanet Odales Bernal ${ }^{1}$; Edelbis López Dávila²; Lisbet López González ${ }^{3}$; Janet Jiménez Hernández ; Ernesto L. Barrera Cardoso ${ }^{5}$

\begin{abstract}
ARTICLE DATA
Assistant professor, M.Sc., University of Sancti Spiritus "José Marti", Sancti Spiritus, Cuba, leyanetob@uniss.edu.cu

Assistant professor, Ph.D., University of Sancti Spiritus "José Marti", Sancti Spiritus, Cuba, edelbis86@gmail.com

3 Titular professor, Ph.D., University of Sancti Spiritus "José Martí", Sancti Spiritus, Cuba, llopez@uniss.edu.cu

4 Titular professor, Ph.D., University of Sancti Spiritus "José Martí, Sancti Spiritus, Cuba, janet@uniss.edu.cu

Titular professor, Ph.D., University of Sancti Spiritus “José Marti”, Sancti Spiritus, Cuba, ernestol@uniss.edu.cu
\end{abstract}

Cite: Odales, L.; López, E.; López, L.; Jiménez, J.; Barrera, E. L. (2020). Biofertilizer potential of digestates from small-scale biogas plants in the Cuban context. Revista de Ciencias Agrícolas. 37(2): 14-26.

doi: https://doi.org/10.22267/rcia.203702.134

Received: November 272019

Accepted: October 302020.

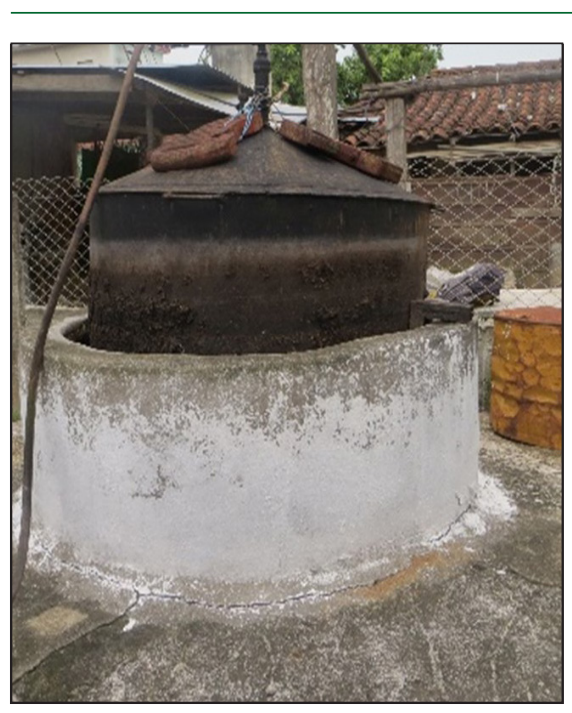

\section{ABSTRACT}

The residual sludge from anaerobic digestion known as digestate has been used as a valuable biofertilizer, but the effect of the substrate, the configuration of the reactor and the operating parameter changes the quality and amounts of nutrients in it. Therefore, it is necessary to know its potential characteristic of fertilizer to apply it correctly in crops of national interest. The aim of this work was to characterize the digestate generated from three biodigester technologies (fixed dome, floating drum and tubular) and three substrates: swine manure, cow manure, and co-digestion of swine and cow manure obtained in the province of Sancti Spíritus, Cuba, in terms of nutrient and matter content. For this purpose, stratified statistical sampling was carried out to ensure representative samples and descriptive statistical techniques were used to process the analyses. The digestate was divided into liquid and solid fractions according to the dry matter content (15\%). The content of organic matter and ash represented around $50 \%$ for both fractions, which enhances its value as a soil conditioner. The nutrient content of both fractions showed good fertilizing properties, having a nutrient ratio $\left(\mathrm{NH}_{4}^{+}: \mathrm{PO}_{4}{ }_{4}^{3-}: \mathrm{K}^{+}: \mathrm{SO}_{4}{ }^{2-}: \mathrm{Mg}^{2+}: \mathrm{Ca}^{2+}\right)$ in the liquid (0.002:0.80:0.10:1.00:0.89:0.93) and solid (0.0003:0.96:0.002:1 $.00: 0.52: 0.50$ ) fractions, that would contribute to the return nutrients to the soil. The quality of the liquid fraction as irrigation water was assessed as good, according to the relationship between the concentration of the nutrients ( $\mathrm{Ca}$, $\mathrm{Mg}$, Na and $\mathrm{K}$ ) and hardness. Further research is needed on the appropriate dosage for the different crops, and its contribution to sustainable agriculture in the Cuban context.

Keywords: biodigester; digestate; fertilizer; irrigation water; nutrient; organic matter.

\section{RESUMEN}

El lodo residual de la digestión anaerobia conocido como digestato ha sido utilizado como un valioso biofertilizante, pero el efecto del sustrato, la configuración del reactor y los parámetros operacionales cambian la calidad y las cantidades de nutrientes en él. Por lo tanto, es necesario conocer su característica potencial de fertilizante para aplicarlo correctamente en 
cultivos de interés nacional. El objetivo de este trabajo fue caracterizar el digestato generado a partir de tres tecnologías de biodigestores (campana fija, campana flotante y tubular) y tres sustratos (estiércol: cerdo, vaca y codigestión de ambos) obtenidos en la provincia de Sancti Spíritus, Cuba, en términos de nutrientes y contenido de materia. Para ello, fue realizado un muestreo estadístico estratificado para asegurar muestras representativas y se usaron técnicas de estadística descriptiva para procesar los análisis. El digestato se dividió en fracciones líquidas y sólidas de acuerdo al contenido de materia seca (15\%). El contenido de materia orgánica y cenizas representó alrededor del 50\% en ambas fracciones, lo que mejora su valor como acondicionador del suelo. El contenido de nutrientes mostró buenas propiedades fertilizantes, con una relación de nutrientes $\left(\mathrm{NH}_{4}^{+}: \mathrm{PO}_{4}{ }^{3-}: \mathrm{K}^{+}: \mathrm{SO}_{4}{ }^{2-}: \mathrm{Mg}^{2+}: \mathrm{Ca}^{2+}\right.$ ) en las fracciones líquidas (0.002: 0.80: 0.10: 1.00: 0.89: 0.93) y sólidas (0.0003: 0.96: 0.002: 1.00: 0.52: 0.50), que contribuirían al retorno de nutrientes al suelo. La calidad de la fracción líquida como agua de riego se evaluó como buena, de acuerdo con la relación entre la concentración de los nutrientes (Ca, Mg, $\mathrm{Na} \mathrm{y} \mathrm{K)} \mathrm{y}$ la dureza. Futuras investigaciones evaluaran la dosis adecuada de digestato para los diferentes cultivos y su contribución a la agricultura sostenible en el contexto cubano.

Palabras clave: agua de riego; biodigestor; digestato; fertilizante; materia orgánica; nutriente.

\section{INTRODUCTION}

Anaerobic digestion (AD) has proven to be an economically feasible technology for the cyclic use of large-scale and small-scales organic waste (Huang et al., 2016; Alkhalidi et al., 2019). It is a widely used to convert organic material into energy-rich biogas and the residual sludge known digestate (Alburquerque et al., 2012). Digestate can be used as a biofertilizer for arable land, enabling recirculation of plant nutrients, and thus reducing the need for fossil fuel-dependent inorganic fertilizers (Alkhalidi et al., 2019). The rapid development of biogas plants in European countries has increased the recycling of waste for energy generation, while producing large quantities of digestate (Franchino et al., 2016). There has been a tendency in the last decades of increased emphasis on improved sustainability in agriculture and preservation of natural resources, thus changing the focus of digestate processing from nutrient removal and disposal, to integrated nutrient recovery and recycling (Drosg et al., 2015). This contributes to promoting the circular economy in the agroindustrial sector, relevant aspect at present (Suárez et al., 2019). The use of digestate has great importance, especially in developing countries, not only because inorganic fertilizers are often too expensive, but also because recycling nutrients from organic sources is essential.

The concentration variability of macronutrients, micronutrients and matter in digestate depends on substrate type, the anaerobic digestion performance and the digestate postreatment like type of solid-liquid separation (Makádi et al., 2012; Akhiar et al., 2017). When digestate is obtained from different manures, the nutrient composition is greatly dependent on several factors such as digestion type (omnivore, ruminant), sex, species, age and diet of the animals, as well as the geographical and climatic conditions of the regions (Lukehurst et al., 2010; Risberg et al., 2017).

In Cuba, researchers have been mainly focused on the direct application of digestate on beans (Negrin Brito and Jiménez Peña, 2012), tomatoes (Utria-Borges et al., 2008; López Dávila et al., 2017a), carrot, radish (Hernández et al., 2008) and onion (López Dávila et al., 2017b). These authors focused on digestate application to crops and its effect on plants. In all cases, they obtain benefits in terms of crop yield. However, very few information was found on the characteristics of the digestate applied (considering the type of biodigester and the substrate used for AD) in the Cuban context; which 
leads to excessive application of nutrients in crops becoming toxic for plants. The characterization of Cuban digestate in terms of nutrient and matter contents can enable to assess it as biofertilizer and use it safely, with possible positive impacts on crop yields and reduction in the use of inorganic fertilizer. Therefore, the aim of this work is to characterize the digestate obtained in the province of Sancti Spíritus, Cuba, in terms of nutrient and matter content, considering the type of biodigester and the substrate used during $\mathrm{AD}$ processes. To this end, the objectives were (i) to classify the digestate in terms of liquid and solid fraction, (ii) to determine the content of matter and nutrients using classical and instrumental analytical techniques, as well as (iii) to evaluate the liquid fraction as irrigation water. The characterization of the digestate can determinate its biofertilizer potential, which has positive environmental impact due to the recirculation of nutrients from substrates considered waste and the decrease in the demand of inorganic fertilizer. Which help reduces the exploitation of natural reserves and also the high pollution that is generated in the industrial manufacture of these inorganic fertilizer.

\section{MATERIALS AND METHODS}

The methods applied to fulfill the objective of this research are described in this section. Firstly, overviews of the existing biodigester technologies in Sancti Spíritus $\left(21^{\circ} 56^{\prime} 02^{\prime \prime} \mathrm{N} 79^{\circ} 26^{\prime} 38^{\prime \prime} \mathrm{W}\right)$, Cuba are briefly described. Later, the methods for the sampling procedure, the physical-chemical analysis and the characterization as irrigation water are also explained.

Biodigester technologies. The most widespread biodigesters in Cuba are: fixed dome biodigester, floating drum biodigester and tubular biodigester (Suárez-Hernández et al., 2018).

Fixed dome biodigesters. Consist of a closed system, usually built of masonry and under ground level. These biodigesters have a fixed dome-shaped cover that contains the biogas inside, an inlet to feed the substrate, and a digestate outlet that allow solid and liquid phases separation to produce digestate in both states, without mechanical process. The lack of agitation in this technology allows the solids to form flocs and precipitate to the bottom of the reactor (increasing the solid retention time), while in the compensation tank the liquid digestate comes out by overflow. The sludge, together with other non-degraded materials that precipitate, is extracted every 15 or 30 days and forms the solid digestate.

Floating drum biodigesters. are formed by a masonry cylinder in its lower part (with a stop to support the bell), and a floating bell storing the gas in the upper part. Inside the reactor, the substrate flows uniformly allowing a better contact of the microorganism and the substrate, and a higher degradation of the organic matter with respect to fixed dome biodigesters. The digestate is collected as sludge.

Tubular biodigesters. are formed by a bag resistant to environmental conditions. The substrates are fed by the inlet pipe and occupy the bottom of the bag while the upper part serves as a container for the biogas generated during the operation. Once the fed substrate has been digested, the digestate leaves the bag through the outlet pipe, coming out in the form of sludge, similar to the floating drum biodigester.

Digestate collection. The number of samples was calculated using the methodology established by Vivanco (2005) through equation 1 :

$$
\mathrm{n}=\frac{\mathrm{NZ} \mathrm{Z}^{2 *} \mathrm{pq}}{\mathrm{d}^{2}(\mathrm{~N}-1)+\mathrm{Z}^{2 *} \mathrm{pq}}
$$

Where:

$\mathrm{n}$ : number of digesters to be sampled 
$p$ : proportion of digesters in operation $(\mathrm{p}=0.8)$

$q$ : proportion of digesters out of operation (1- $p)$ $(q=0.2)$

$\mathrm{N}$ : size of the population (number of digesters)

$Z$ : deviation from the mean value accepted to achieve the desired level of confidence, based on the $95 \%$ confidence level, with $\mathrm{Z}=1.96$.

$d$ : level of absolute precision, referring to the amplitude of the confidence interval desired in the determination of the average value of the variable under study. This value was taken as 0.16 .

Taking into account the existence of several types of digesters in the province of Sancti Spíritus and the different types of substrates, it is necessary to carry out a random stratified sampling procedure (descriptive analysis), to ensure that each technology and substrate are proportionally represented in the final sample. For that aim, equation 2 was used (Vivanco, 2005):

$$
\mathrm{fh}=\frac{\mathrm{n}}{\mathrm{N}}
$$

Where:

fh: fraction of the stratum; n: sample size; $\mathrm{N}$ : population size.

The following operating parameters: temperature range, hydraulic retention time, reactor volume, feeding substrate and methane productivity were considered in the descriptive analysis and evaluation in the equation 1 and 2 .

The digestate was taken in all cases at the biodigesters outlet. The collection of samples in tubular and floating drum biodigesters was carried out by using a valve located in the lower part of the biodigesters. In the fixed dome biodigesters, the liquid and solid fractions were collected separately as the technology allows that. The liquid fraction was taken from the compensation tank, prior to the exit of the pos-treatment system (lagoons); while the solid fraction was collected from the sludge outlet at the biodigester bottom. All samples were stored in sterile glass bottles and kept in freezing at $-20^{\circ} \mathrm{C}$ to avoid biodegradation until their analysis.

Physical - chemical analyses. As the liquid digestate is highly colored and turbid due to the presence of suspended matter, all digestate were converted to ashes. The ashes were used for determining sodium, potassium, sulfate, phosphate, calcium and magnesium, matters content, electrical conductivity and ammonium nitrogen were determinate in fresh samples.

For the physical-chemical characterization of digestate, The Standard Methods for the Examination of Water and Wastewater (APHA 2012) were used. The content of dry matter (DM, \%) (section 2540-B), fixed matter (ash, \%) (section 2540-E) and organic matter (OM, \%) (section 2540-E), were determined by gravimetric methods. Calcium $\left(\mathrm{Ca}^{2+}\right)$ and magnesium $\left(\mathrm{Mg}^{2+}\right)$ were determined by complexometric titration (sections 3500-Ca-B and 3500-Mg-B, respectively); Orthophosphate (section 4500- $\mathrm{PO}_{4}{ }^{3-}-\mathrm{C}$ ) and sulfate (section 4500-SO ${ }_{4}^{2-}-\mathrm{E}$ ), by spectrophotometry; and ammonium nitrogen by (Kjendalh) (section $4500-\mathrm{NH}_{4}^{+}-\mathrm{C}$ ). In addition, it was determined Potassium $\mathrm{K}_{2} \mathrm{O}-\mathrm{K}$ (section 3500-K-B) and sodium $\mathrm{Na}_{2} \mathrm{O}-\mathrm{Na}$ (section $3500-\mathrm{Na}-\mathrm{B}$ ), by flame photometry, whereas the electrical conductivity (EC) were determined by conductimetry (section 2520-Salinity-B).

Characterization as irrigation water. To assess the quality of the liquid fraction of digestate as water for irrigation, the sodium adsorption ratio (SAR) (Del Valle, 1992) and the Kelly ratio (KR) (Quispe Mamani, 2016) were used (Equations 3 and 4 , respectively). In addition, the relationship of both parameters with the hardness and electrical conductivity was taken into account to classify the quality of digestate as irrigation water. 


$$
\begin{aligned}
& \mathrm{SAR}=\frac{c(\mathrm{Na})}{\sqrt{\frac{c(\mathrm{Ca})+c(\mathrm{Mg})}{2}}} \\
& \mathrm{KR}=\frac{\mathrm{c}(\mathrm{Ca})}{\mathrm{c}(\mathrm{Ca})+\mathrm{c}(\mathrm{Mg})+\mathrm{c}(\mathrm{Na}) \times 100}
\end{aligned}
$$

Where $\mathrm{c}(\mathrm{Na})$ is the sodium concentration (meq $\mathrm{L}^{-1}$ ), $c(\mathrm{Ca})$ is the calcium concentration (meq $\mathrm{L}^{-1}$ ) and $\mathrm{c}(\mathrm{Mg})$ is the magnesium concentration (meq $\left.\mathrm{L}^{-1}\right)$.

Statistical analysis. All statistical descriptive analysis (biodigestor technology and substrate used frequency as well as predominant nutrient and matter contents per substrate) performed in the selection and evaluation of technologies and samples were done with SPSS software, version 23,0 (SPSS, 2013). The analyses were performed in triplicate, the central tendency and dispersion statistics (mean, standard error of the mean, and ranges) were calculated as shown in the figures and tables of the study.

\section{RESULTS AND DISCUSSION}

Digestates were collected from 20 biodigesters (according to the results from equation 1), located 11 in Cabaiguán municipality $\left(22^{\circ} 05^{\prime} 02^{\prime \prime} \mathrm{N} 79^{\circ} 29^{\prime} 43^{\prime \prime} \mathrm{W}\right)$ and 9 in Banao town $\left(21^{\circ} 82^{\prime} 86^{\prime \prime} \mathrm{N} 79^{\circ} 56^{\prime} 86^{\prime \prime} \mathrm{W}\right)$. To ensure representative samples, three strata were formed in accordance with the type of biodigester (Table 1), which consists of 13 fixed dome, 1 floating drum and 6 tubular biodigesters, (according to equation 2). In addition, in accordance with the type of substrates, three strata were also considered consisting of 13 swine manure (SM), 2 cow manure (CM) and 5 codigestion of swine and cow manure (SCM) (equation 2).

Table 1 shows, the operating parameters: temperature range (mesophilic) and hydraulic retention time (HRT) (15-50 days), were equal for all plants; while reactor volume (1.8-50 $\mathrm{m}^{3}$ ) and feeding (2-4 $\mathrm{kg}$ of volatile solid/day $/ \mathrm{m}^{3}$ ) were different. The methane productivity of all plants was $0.5 \mathrm{~m}^{3}$ reactor/day).

As $50 \%$ of the digestate produced in Sancti Spíritus, corresponds to fixed dome biodigesters treating SM, they were the higher strata (13 biodigesters). This can be attributed to the decentralized pig production in Cuba, the necessity for SM treatment in situ and the high dissemination of fixed dome biodigesters (Sosa et al., 2014). For that reason, this substrate and this technology were chosen for a more detailed analysis in the present study.

\section{Digestate characterization}

Dry matter. The content of dry matter (DM), organic matter (OM) and ash for SM digestate (solid and liquid fractions) obtained from fixed dome biodigesters is shown in Figure 1.

Table 1. Operating parameters and methane productivity for small-scale biodigesters which produced the digestates studied.

\begin{tabular}{lccccc}
\hline $\begin{array}{c}\text { Biodigesters } \\
\text { types }\end{array}$ & $\begin{array}{c}\text { Reactor } \\
\text { Volume }\left(\mathbf{m}^{3}\right)\end{array}$ & $\begin{array}{c}\text { Temperature } \\
\text { range }\end{array}$ & $\begin{array}{c}\text { Feeding } \\
\left(\mathbf{k g} / \mathbf{d a y} / \mathbf{m}^{3}\right)\end{array}$ & $\begin{array}{c}\text { HRT } \\
(\text { days })\end{array}$ & $\begin{array}{c}\text { Methane productivity } \\
\left(\mathbf{m}^{3} \text { reactor } / \text { day }\right)\end{array}$ \\
\hline Fixed dome & $20-50$ & Mesophilic & 2 & $15-50$ & 0.5 \\
Floating drum & 1,5 & Mesophilic & 2 & $15-50$ & 0.5 \\
Tubular & 3 & Mesophilic & $2-4$ & $15-50$ & 0.5 \\
\hline
\end{tabular}

HRT: hydraulic retention time. 


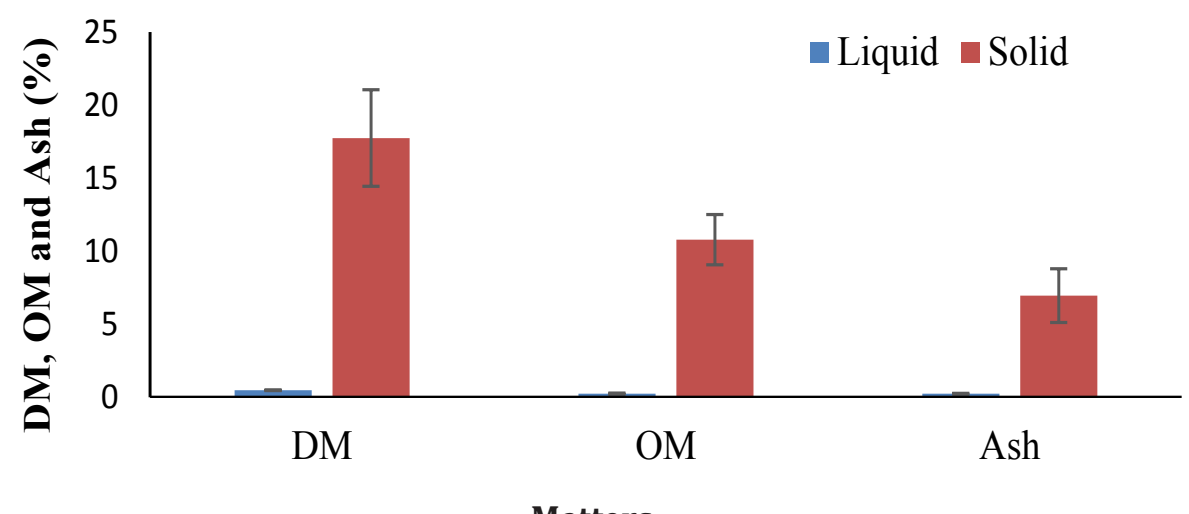

Matters

Figure 1. Contents of dry matter (DM), organic matter (OM) and ash in swine manure (SM) digestate (solid and liquid fractions) obtained from fixed dome biodigesters. The bars indicate the standard deviation.

The solid fraction of the digestate showed a DM content of $17.77 \pm 3.30 \%$ (Figure 1), being considered as a solid digestate, following the approach of Makádi et al. (2012), who suggested this classification for DM content in digestate above $15 \%$. For that reason, SM digestate (solid fraction) obtained from fixed dome biodigesters can be considered as biofertilizer rich in stable and fibrous material which should have a positive effect on soils by minimizing erosion and improving water-holding capacity and soil structure, especially when they are used on sandy soils (Bermejo et al., 2010). The liquid fraction of this digestate presented a very low DM content (average $0.48 \pm 0.03 \%$ ), due to the large dilution of the SM occurring when more than $40 \mathrm{~L}$ of water per animal head are used during the cleaning of piggeries (Sosa et al., 2014).

Organic matter. The efficiency of $0 \mathrm{M}$ conversion through mesophilic (i.e. $35^{\circ} \mathrm{C}$ ) or thermophilic (i.e. $55^{\circ} \mathrm{C}$ ) $A D$ is generally in the range of $13-65 \%$, and depends on the type of substrate fed to the biodigester, as well as on anaerobic reactor parameters, such as the Organic Loading Rate (OLR) and the HRT (Menardo et al., 2011). In the solid and liquid fractions of the SM digestate, OM represented more than $50 \%$ of DM, agreeing with the values reported by Marcato et al. (2008). These high $0 \mathrm{M}$ values can be attributed to several aspects: 1) the high OLR and short HRT applied to fixed dome biodigesters in piggeries; as the number of pigs increases during the time for the same biodigester volume; and 2) the low removal efficiency $(<50 \%)$ of organic matter reported for fixed dome biodigesters due to its cylindrical shape that does not ensure a uniform path of the substrate inside the biodigester (Montalvo and Guerrero, 2003).

These aspects induce a rise of the more recalcitrant molecules in digestates, such as lignin, cutin, humic acids, steroids, complex proteins. These nondegraded stable carbon compounds are beneficial for the soil, being potential humus precursors with high biological stability (Kalakodio et al., 2017; Diacono et al., 2019)"plainCitation":"(Kalakodio et al. 2017; Diacono et al. 2019. This allows increase fertility, functionality, microbial activity, aeration, and water storage capacity in the soil (Kalakodio et al., 2017).

Ash. The ash content in the solid and liquid fractions was 39\% and 50\%, respectively. During $\mathrm{AD}$, organic compounds are broken down by bacteria resulting in the production of methaneand 
carbon dioxide. Thus, as a result of the digestion process, a number of changes in the solid content can be expected; including a substantial reduction (up to 25\%) in the total solids and a consequent increase in the ash content (as \%DM), due to the conservation of minerals and the organic matter removal (Fageria and Moreira, 2011).

Matter content of the remaining digestates. A summary of DM, OM and Ash for the remaining digestates available in Sancti Spíritus is provided in Appendix A. The DM content of the digestate solid fraction obtained from fixed dome biodigester during the treatment of SCM, rendered similar values $(17.50 \pm 1.89 \%)$ with respect to fixed dome biodigester using SM only. However, a lower DM content was obtained in tubular and floating drum biodigesters $(7.08 \pm 0.10 \%$ and $4.42 \pm 0.20 \%$, respectively) treating CM. Tubular biodigesters using SM and SCM reported a DM content of $1.02 \pm 0.03 \%$ and $6.10 \pm 0.30 \%$, respectively. Organic matter and ash represented from $40-50 \%$ and from $20-40 \%$ of DM, respectively. These values make the digestates available in Sancti Spiritus, a suitable soil amendment, based on its matter content.

Nutrient content. Figure 2 shows the nutrient content of SM digestate in term of nitrogen $\left(\mathrm{NH}_{4}{ }^{+} \mathrm{N}\right)$, phosphorous $\left(\mathrm{PO}_{4}{ }^{3-} \mathrm{P}\right)$, sulfates $\left(\mathrm{SO}_{4}{ }^{2-}-\mathrm{S}\right)$, calcium $\left(\mathrm{Ca}^{2+}-\mathrm{Ca}\right)$, magnesium $\left(\mathrm{Mg}^{2+}-\mathrm{Mg}\right)$ and potassium $\left(\mathrm{K}^{+}-\mathrm{K}\right)$ concentrations $\left(\mathrm{g} \mathrm{kg}^{-1} \mathrm{DM}\right)$.

Nitrogen. $\mathrm{TheNH}_{4}{ }^{+}$-Nconcentrationinbiofertilizers is of great importance as it is immediately available to the plant. The concentrations of $\mathrm{NH}_{4}^{+}-\mathrm{N}$ in the liquid and solid fractions were $0.06 \pm 0.00$ and 0.01 $\pm 0.00 \mathrm{~g} \mathrm{NH}_{4}{ }^{+} \mathrm{kg}^{-1} \mathrm{DM}$, respectively. The $\mathrm{N}$ content of the digestate was a consequence of its preservation during AD (Tambone et al., 2010; Drosg et al., 2015). During organic matter degradation, part of the organically bound nitrogen is reduced to the $\mathrm{NH}_{4}$ form, (Kuusik et al, 2017). The $\mathrm{NH}_{4}{ }^{+} \mathrm{N}$ is concentrated in the digestate by the degradation of the proteins available in the fed substrate (Kryvoruchko et al., 2009). Typically, pigs include a high protein content in their diet (e.g., animal feed, food waste and slaughterhouse waste), as part of these proteins are not assimilated by the pigs, being expelled in the excreta; they are degraded to $\mathrm{NH}_{4}^{+}$during the $\mathrm{AD}$ process and released in the liquid digestate mainly.

For that reason, values between 1.00 and $1.80 \mathrm{~g}$ of $\mathrm{NH}_{4}{ }^{+} \mathrm{kg}^{-1} \mathrm{DM}$ has been considered as typical for the liquid digestate obtained from biogas plants treating SM (Rossi and Mantovi, 2012; Tigini

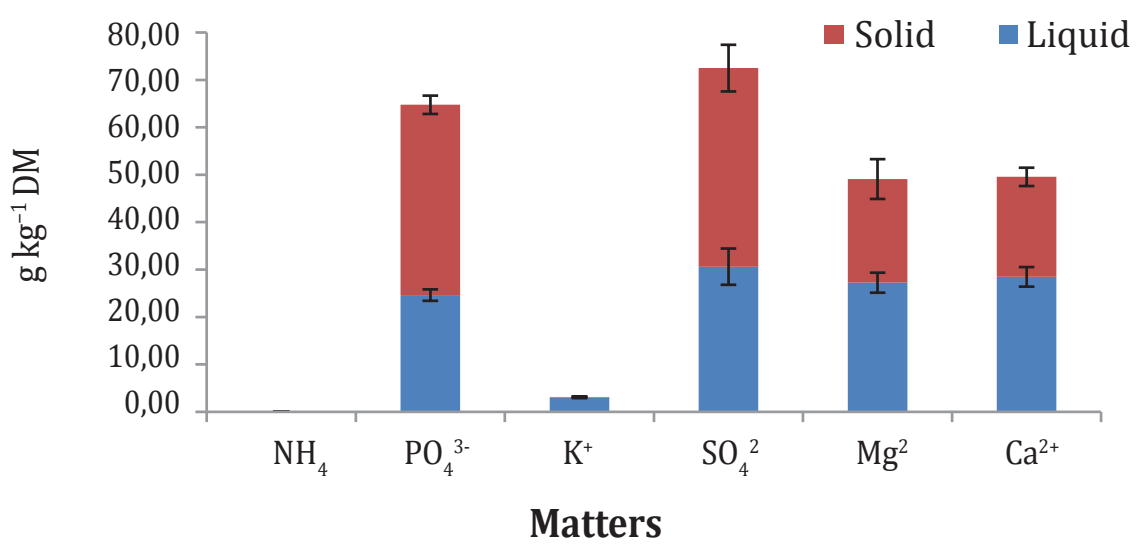

Figure 2. Nutrient content expressed in g per kg of dry matter (DM), in the swine manure (SM) digestate (solid and liquid fractions). The bars indicate the standard deviation. 
et al., 2016). However, in this study the $\mathrm{NH}_{4}^{+}-\mathrm{N}$ concentration in the liquid fraction was $0.06 \mathrm{~g}$ of $\mathrm{NH}_{4}^{+} \mathrm{kg}^{-1} \mathrm{DM}$, being $60 \%$ of the typical values reported (Rossi and Mantovi, 2012; Tigini et al., 2016). The higher concentration of $\mathrm{N}$ for the liquid fraction with respect to the solid fraction, agreed with Tampio, Marttinen and Rintala (2016), who stated that solid-liquid separation is increasing in application during digestate treatment for the extraction of nitrogen from the liquid fraction.

Phosphorous. The phosphorus content of digestate is expressed as total phosphorus or as phosphate equivalents. The AD process does not affect the content of phosphate in digestate, which is mostly dependent on the content in the substrate (Drosg et al., 2015). The concentration of $\mathrm{PO}_{4}^{3-}-\mathrm{P}$ obtained in this study for the liquid fraction digestate, was $14.63 \pm 1.20 \mathrm{~g}$ $\mathrm{kg}^{-1} \mathrm{DM}$, agreeing with the values reported in Alburquerque et al. (2012), being 7 times higher than the values ( 1 to $2 \mathrm{~g} \mathrm{PO}_{4}^{3-} \mathrm{kg}^{-1} \mathrm{DM}$ ) reported by Rossi and Mantovi (2012).

The concentration of $\mathrm{PO}_{4}^{3-}-\mathrm{P}$ for the solid fraction digestate was $40.14 \pm 1.93 \mathrm{~g} \mathrm{~kg}^{-1} \mathrm{DM}$, showing that phosphorous is mainly accumulated in the solid fraction of digestates, which agree with the values reported by Tampio et al. (2016) (Figure 2). Phosphates are a limited non-renewable resource, which is as an essential plant nutrient that cannot be replaced by other substances (Shepherd et al., 2016). Therefore, the use of this digestate for the Cuban agriculture can generate economic and environmental benefits, by substituting P-rich commercial biofertilizers; which is of prime importance in the recycling of limiting nutrients like phosphorous.

Potassium. Potassium concentrations of $0.09 \pm 0.00 \mathrm{~g} \mathrm{~kg}^{-1}$ and $3.06 \pm 0.17 \mathrm{~g} \mathrm{~kg}^{-1} \mathrm{DM}$ were obtained for the solid and liquid fractions of the digestate, respectively. Alburquerque et al. (2012) reported values from 50 to 1000 times higher for the liquid and solid fractions, respectively. As potassium degradation during $\mathrm{AD}$ is negligible, the differences found in potassium concentration can be attributed to the pig diet in the different regions. For example, pigs Cuban farms eats cereals but also home-made food such as cassava and sweet potato yogurt (Almaguel et al., 2016) castrated males and females in equal proportion of 85 days old with an average initial weight of $30.0 \mathrm{~kg}$. The pigs were distributed according to a random blocks design in four experimental treatments and 12 replicates per treatment (position inside the pen.

Sulfates. A high sulfate concentration of the solid and liquid fractions was observed, with average concentrations of $41.89 \pm 4.92$ and $30.61 \pm 3.82 \mathrm{~g}$ $\mathrm{kg}^{-1} \mathrm{DM}$, respectively (Figure 2). These values were similar to those reported by Chen et al. (2010), who states that this is also related to the proteins consumption in the pigs diet.

Calcium and Magnesium. In the solid and liquid fractions, the $\mathrm{Ca}: \mathrm{Mg}$ ratio was around 1:1; being these values lower than those reported by (Negrin Brito and Jiménez Peña, 2012) for a digestate obtained from the $\mathrm{AD}$ of agricultural waste and manure (88 Ca\% and $12 \mathrm{Mg} \% \mathrm{DM}$ ). A further discussion will be provided in the next section about $\mathrm{Ca}$ and $\mathrm{Mg}$ concentrations in the liquid fraction of the SM digestate.

In general, $\mathrm{AD}$ enables the attainment of a final product (digestate) with good fertilizing properties, having a nutrient ratio $\left(\mathrm{NH}_{4}^{+}: \mathrm{PO}_{4}^{3-}\right.$ : $\left.\mathrm{K}^{+}: \mathrm{SO}_{4}^{2-}: \mathrm{Mg}^{2+}: \mathrm{Ca}^{2+}\right)$ in the liquid $(0.002: 0.80: 0.10$ :1.00:0.89:0.93) and solid (0.0003:0.96:0.002:1. $00: 0.52: 0.50$ ) fractions, that would contribute to return macronutrients to the soil after AD of SM. A summary of the nutrient content for the digestates available in Sancti Spíritus is provided in Table 2. 


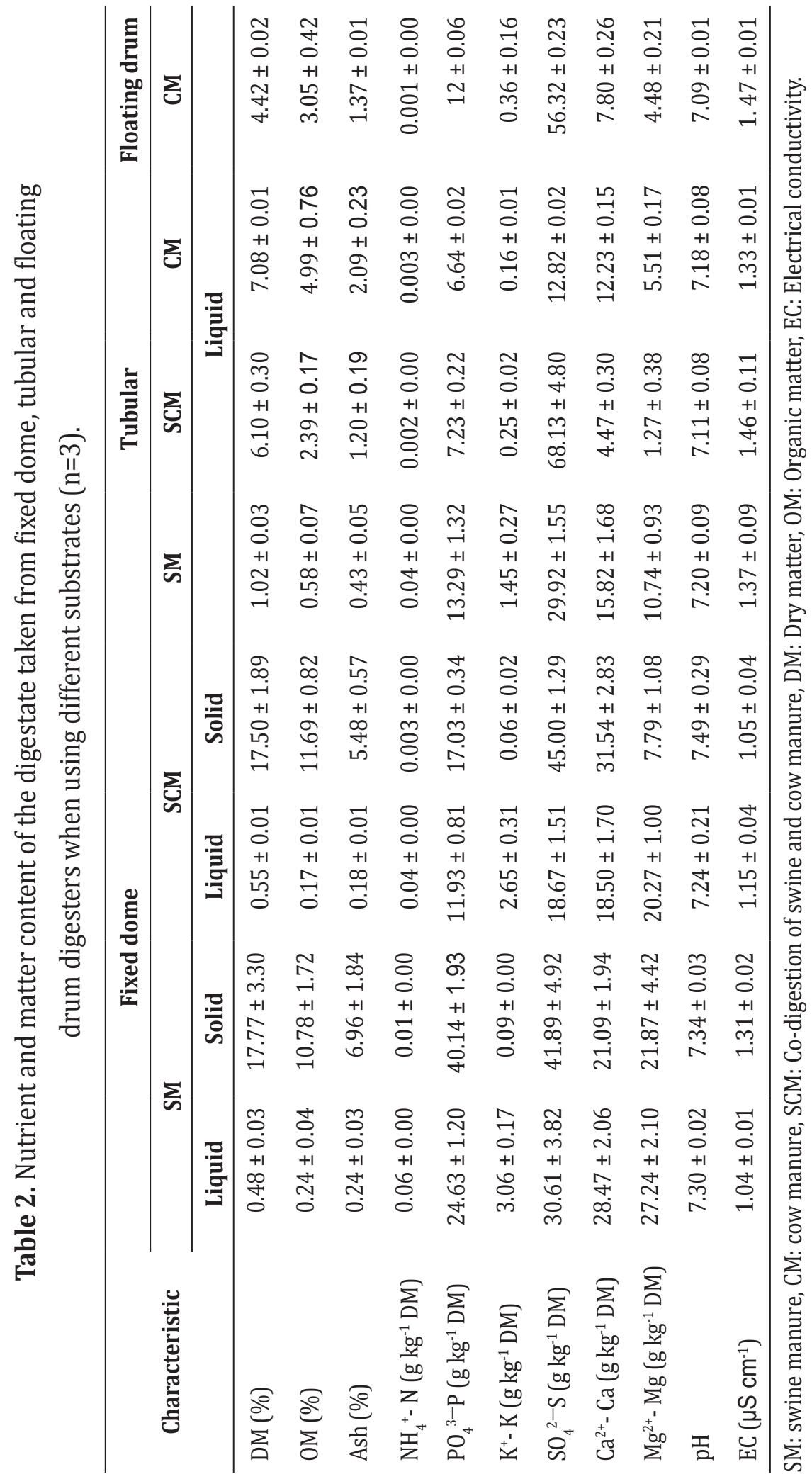


Liquid fraction of digestate as irrigation water. The liquid fraction generated from SM was assessed as water for irrigation based on its content of interchangeable ions, EC and hardness. Table 3 shows the experimental measurements, the calculations of these parameters and their acceptance criteria.

SAR and KR were calculated according to equations described by Del Valle (1992) and Quispe Mamani (2016), respectively. The SAR value was 0.03 for the liquid digestate, indicating its low sodification power. In general, the higher the SAR, the less suitable the water is for irrigation (Aboukarima et al., 2018)in the order $305>240>137>104$ $>65 \mathrm{~mm} / \mathrm{h}$ for SAR of 3.34, 3.52, 4.14, 4.18, and 7.60 , respectively. The results showed that 180 min after the initial time of measurement in the sandy-loam soil, the final infiltration rates were in the range of $21.1-44.0 \mathrm{~mm} / \mathrm{h}$ for the different qualities of water considered in this study, with an average value of $33.8 \mathrm{~mm} / \mathrm{h}$. Hence, the infiltration rate is sensitive to the SAR of the applied water. The final infiltration rate (IRf. That is either diminish the soil permeability, reducing the formation of crusts that can modify the physical-chemical properties of the soil with the consequent deterioration of the crop yield (Lesch and Suarez, 2009). Moreover, the KR value for the liquid digestate $(<28 \%)$ was lower than the optimum value (higher than 35\%) for plant growing (Quispe Mamani, 2016), because of the higher proportion of $\mathrm{Mg}$ with respect to $\mathrm{Ca}$, and the low contribution of $\mathrm{Na}$ concentration (see Eq. 4). In terms of hardness, the digestate was considered as very hard water $\left(78.5^{\circ} \mathrm{F}\right)$ because its values were higher than the acceptance criterion of $54^{\circ} \mathrm{F}$.

According to the diagram for the interpretation of the irrigation water value (Riverside Standards) (Olías et al., 2005), digestate was classified as C3S1. That is, digestate has highly saline waters (EC $1320 \mu \mathrm{S} \mathrm{cm}^{-1}$ ); therefore, there must be good drainage conditions, salinity must be controlled and only plants that are resistant to salinity should be cultivated. On the other hand, it presents a low alkalization hazard ( $\mathrm{SAR}=0.03$ ), so it can be used without serious damage to plant development.

Besides, according to the Wilcox Standard (Olías et al., 2005), which takes into account the percentage of $\mathrm{Na}$ over the other cations ( $\mathrm{Ca}, \mathrm{Mg}$ and $\mathrm{K}$ ) and the EC, it was obtained that the digestate of Sancti Spiritus is in the category from "good" to "admissible", representing a potential alternative to increase agriculture sustainability in the Cuban context. Further studies are needed on the appropriate dosage for the different crops.

Table 3. Evaluation of swine manure liquid fraction digestate as water irrigation.

\begin{tabular}{|c|c|c|c|c|}
\hline Parameters & $\mathrm{EC}\left(\mu S^{*} \mathrm{~cm}^{-1}\right)$ & Hardness $\left({ }^{\circ} \mathrm{F}\right)$ & SAR & KR (\%) \\
\hline Liquid digestate & 1320.00 & 78.50 & 0.03 & 28.22 \\
\hline Acceptance requirements & $\begin{array}{l}<750 \text { Excellent } \\
750-3000 \text { Good } \\
>3000 \text { Unacceptable }\end{array}$ & $\begin{array}{l}0-22 \text { Sweet } \\
32-54 \text { Hard } \\
>54 \text { Very hard }\end{array}$ & $<10$ 0ptimum & $>35$ 0ptimum \\
\hline
\end{tabular}

SAR: Sodium Adsorption Ratio, KR: Kelly's ratio, EC: Electrical conductivity. 


\section{CONCLUSION}

The digestates obtained in biodigesters in the province of Sancti Spíritus, Cuba were characterized in terms of nutrient and matter content. Most of the digestate samples (50\%) were taken from fixed dome biodigesters treating SM because they were widely available in Sancti Spíritus.

The highest dry matter content (DM) was obtained for the solid digestate sampled from fixed dome biodigesters, with values above 17\%, being considered as stable and fibrous material which should have a positive effect on soils, by minimizing erosion and improving water-holding capacity and soil structure.

The nutrient content of both digestates showed good fertilizing properties, having a nutrient ratio $\left(\mathrm{NH}_{4}^{+}: \mathrm{PO}_{4}^{3-}: \mathrm{K}^{+}: \mathrm{SO}_{4}^{2-}: \mathrm{Mg}^{2+}: \mathrm{Ca}^{2+}\right)$ in the liquid (0.002:0.80:0.10:1.00: 0.89:0.93) and solid (0.000 $3: 0.96: 0.002: 1.00: 0.52: 0.50)$ fractions, that would contribute to the return of organic matter and nutrients to the soil in a short-term period.

Swain manure treated in fixe dome biodigester was the one that produced the most nutrient-rich digestate, therefore, it was the one with the highest biofertilizing potential.

The quality of the liquid fraction as irrigation water was assessed as good, according to the relationship between the concentration of the nutrients $(\mathrm{Ca}$, $\mathrm{Mg}, \mathrm{Na}$ and $\mathrm{K}$ ) and hardness, agreeing with the water classification for irrigation of the Wilcox and Riverside standards.

Conflict of interest: The authors declare that there is no conflict of interest.

\section{BIBLIOGRAPHIC REFERENCES}

Aboukarima, A.M.; Al-Sulaiman, M.A.; Marazky, M.S.A.E. (2018). Effect of sodium adsorption ratio and electric conductivity of the applied water on infiltration in a sandy-loam soil. Water SA. 44(1): 105-110. doi: 10.4314/wsa.v44i1.12

Akhiar, A.; Battimelli, A.; Torrijos, M.; Carrere, H. (2017). Comprehensive characterization of the liquid fraction of digestates from full-scale anaerobic co-digestion. Waste management. 59: 118-128. doi: 10.1016/j.wasman.1016.11.005

Alburquerque, J.A.; De la Fuente, C.; Campoy, M.; Carrasco, L.; Nájera, I.; Baixauli, C.; Caravaca, F.; Roldán, A.; Cegarra, J.; Bernal, M.P. (2012). Agricultural use of digestate for horticultural crop production and improvement of soil properties. European Journal of Agronomy. 43: 119-128. doi: 10.1016/j.eja.2012.06.001

Alkhalidi, A.; Khawaja, M.K.; Amer, K.A.; Nawafleh, A.S.; Al-Safadi, M.A. (2019). Portable Biogas Digesters for Domestic Use in Jordanian Villages. Recycling. 4(2): 21. doi: $10.3390 /$ recycling 4020021

Almaguel, R.E.; Cruz, E.; Piloto, J.L. (2016). Aceptabilidad y patrón de consumo de cerdos en crecimiento-ceba alimentados con diferentes niveles de sustitución del maiz de la dieta por alimento ensilado cubano. Revista computarizada de producción porcina. 23(2): 137-146.

Angelidaki, I.; Ellegaard, L.; Ahring, B.K. (2003). Applications of the anaerobic digestion process. In Biomethanation II. 82: 1-33. doi: 10.1007/3-54045838-7_1

APHA - American Public Health Association. (2012). Standard Methods for the Examination of Water and Wastewater. 22nd ed. Washington D.C.: American Water Works Association, Water Environment Federation and American Public Health Association.

Bermejo, G.; Ellmer, F.; Krück, S. (2010). Use of dry and wet digestates from biogas plants as fertilizer in plant production. Recovered from http://ramiran. uvlf.sk/ramiran2010/docs/Ramiran2010_0089_ final.pdf 
Chen, J.; Michel Jr, F.C.; Sreevatsan, S.; Morrison, M.; Yu, Z. (2010). Occurrence and persistence of erythromycin resistance genes (erm) and tetracycline resistance genes (tet) in waste treatment systems on swine farms. Microbial ecology. 60(3): 479-486. doi: 10.1007/s00248-010-9634-5

Del Valle, H. (1992). Practicas de Relaciones Agua-SueloAtmosfera. México: Editorial Universidad Autónoma de Chapingo. 210p.

Diacono, M.; Persiani, A.; Testani, E.; Montemurro, F.; Ciaccia, C. (2019). Recycling Agricultural Wastes and By-products in Organic Farming: Biofertilizer Production, Yield Performance and Carbon Footprint Analysis. Sustainability. 11: 3824. doi: 10.3390/ su11143824

Drosg, B.; Fuchs, W.; Al Seadi, T.; Madsen, M.; Linke, B. (2015). Nutrient Recovery by Biogas Digestate Processing. Dublin: IEA Bioenergy. 39p.

Fageria, N. K.; Moreira, A. (2011). The Role of Mineral Nutrition on Root Growth of Crop Plants. Advances in agronomy. 110: 251-331. doi: 10.1016/B978-0-12385531-2.00004-9

Franchino, M.; Tigini, V.; Varese, G.C.; Sartor, R.M.; Bona, F. (2016). Microalgae treatment removes nutrients and reduces ecotoxicity of diluted piggery digestate. Science of The Total Environment. 569: 40-45. doi: 10.1016/j.scitotenv.2016.06.100

Hernández, M. F.; Prieto, C. R. H.; Sonia, C.; González, J.; Sanchez, J. V. (2008). Los biodigestores como aportadores de energía y mejoradores del suelo. Recovered from https://docplayer.es/45125012Los-biodigestores-como-aportadores-de-energia-ymejoradores-del-suelo.html

Huang, X.; Yun, S.; Zhu, J.; Du, T.; Zhang, C.; Li, X. (2016). Mesophilic anaerobic co-digestion of aloe peel waste with dairy manure in the batch digester: Focusing on mixing ratios and digestate stability. Bioresource technology. 218: 62-68. doi: 10.1016/j. biortech.2016.06.070

Kalakodio, L.; Alepu, O.E.; Zewde, A.A. (2017). Application of techniques derived from the study of soil organic matter to characterize the organic matter during the composting of various materials-A Review. Journal of Pollution Effect and Control. 5: 184-94. doi: 10.4176/2375-4397.1000184
Kryvoruchko, V.; Machmüller, A.; Bodiroza, V.; Amon, B.; Amon, T. (2009). Anaerobic digestion of byproducts of sugar beet and starch potato processing. Biomass and Bioenergy. 33: 620-627. doi: 10.1016/j. biombioe.2008.10.003

Kuusik, A.; Pachel, K.; Kuusik, A.; Loigu, E. (2017). Possible agricultural use of digestate. Proceedings of the Estonian academy of sciences. 66: 64-74. doi: 10.3176/proc.2017.1.10

Lesch, S.M.; Suarez, D.L. (2009). Technical Note: A Short Note on Calculating the Adjusted SAR Index. Transactions of the ASABE. 52: 493-496.

López Dávila, E.; Calero Hurtado, A.; Gómez León, Y.; Unday, G. Z., C.; Deborah Henderson, C.; Janet Jimenez, C. (2017a). Agronomic effect of the biosolid in tomato cultivation (Solanum lycopersicum): biological control of Rhizoctonia solani. Cultivos Tropicales. 38: 13-23.

López Dávila, E.; Unday, Z.G., Henderson, D., Hurtado, A.C.; Hernández, J.J. (2017b). Uso de efluente de planta de biogás y microorganismos eficientes como biofertilizantes en plantas de cebolla (Allium cepa L., cv. 'Caribe-71'). Cultivos Tropicales. 38(4): 7-14.

Lukehurst, C.T.; Frost, P.; Seadi, T.A. (2010). Utilisation of digestate from biogas plants as biofertiliser. Dublin: IEA Bioenergy. 24p.

Makádi, M.; Tomócsik, A.; Orosz, V. (2012). Digestate: a new nutrient source-review. Biogas. 14: 295-312. doi: $10.5772 / 31355$.

Marcato, C.E.; Pinelli, E.; Pouech, P.; Winterton, P.; Guiresse, M. (2008). Particle size and metal distributions in anaerobically digested pig slurry. Bioresource Technology. 99: 2340-2348. doi: 10.1016/j.biortech.2007.05.013

Menardo, S.; Gioelli, F.; Balsari, P. (2011). The methane yield of digestate: effect of organic loading rate, hydraulic retention time, and plant feeding. Bioresource technology. 102: 2348-2351. doi: 10.1016/j.biortech.2010.10.094

Montalvo, S.; Guerrero, L. (2003). Tratamiento Anaerobio de Residuos. 1st ed. Chile: Universidad Técnica Federico Santa María.

Negrin Brito, A.; Jiménez Peña, Y. (2012). Evaluación del efecto agronómico del biosólido procedente de una planta de tratamiento por digestión anaerobia de residuales pecuarios en el cultivo del frijol (Phaseolus vulgaris L). Cultivos Tropicales. 33: 13-19. 
Olías, M.; Cerón, J.; Fernández, I. (2005). Sobre la utilización de la clasificación de las aguas de riego del US Laboratory Salinity (USLS). Geogaceta. 111-113.

Quispe Mamani, J.G. (2016). Evaluación de la Calidad fisico- química y bacteriológica del agua de riego de la Estación Experimental de Cota Cota. Pregrado, La Paz, Bolivia: Universidad Mayor de San Andres.

Risberg, K.; Cederlund, H.; Pell, M.; Arthurson, V.; Schnürer, A. (2017). Comparative characterization of digestate versus pig slurry and cow manure Chemical composition and effects on soil microbial activity. Waste Management. 61: 529-538. doi: 10.1016/j.wasman.2016.12.016

Rossi, L.; Mantovi, P. (2012). Digestato, un utile sottoprodotto per il biogas. Centro Ricerche Produzioni Animali- CRPA (Ed.), Conoscere per comprendere, Reggio Emilia, Italy.

Shepherd, J.G.; Sohi, S.P.; Heal, K.V. (2016). Optimising the recovery and re-use of phosphorus from wastewater effluent for sustainable fertiliser development. Water Research. 94: 155-165. doi: 10.1016/j.watres.2016.02.038

Sosa, R.; Cruz, T.; de la Fuente, J.L. (2014). Diversification and overviews of anaerobic digestion of Cuban pig breeding. Cuban Journal of Agricultural Science. 48: $67-72$.

Suárez, J.L.R.; Avendaño, C.L.V.; González, J.M.; Pérez, A.C. (2019). Evaluation of poultry manure and goat cheese whey anaerobic co-digestion. Spanish Journal of Agricultural Research. 17(2): 302.

Suárez-Hernández, J.; Sosa-Cáceres, R.; MartínezLabrada, J.; Curbelo-Alonso, A.; Figueredo-Rodríguez, T.; Cepero-Casas, C. (2019). Evaluation of the biogas production potential in Cuba. Pastos y Forrajes. 41(2): 79-85

Tambone, F.; Scaglia, B.; D’Imporzano, G.; Schievano, A.; Orzi, V.; Salati, S.; Adani, F. (2010). Assessing amendment and fertilizing properties of digestates from anaerobic digestion through a comparative study with digested sludge and compost. Chemosphere, 81: 577-583. doi: 10.1016/j. chemosphere.2010.08.034

Tampio, E.; Marttinen, S.; Rintala, J. (2016). Liquid fertilizer products from anaerobic digestion of food waste: mass, nutrient and energy balance of four digestate liquid treatment systems. Journal of Cleaner Production. 125: 22-32. doi: 10.1016/j. clepro.2016.03.127

Tigini, V.; Franchino, M.; Bona, F.; Varese, G.C. (2016). Is digestate safe? A study on its ecotoxicity and environmental risk on a pig manure. Science of The Total Environment. 551: 127-132. doi: 10.1016/j. scitotenv.2016.02.004

Utria-Borges, E.; Cabrera-Rodríguez, J.A.; ReynaldoEscobar, I.M.; Morales-Guevara, D.; Fernández, A.M.; Toledo Toledo, E. (2008). Utilización agraria de los biosólidos y su influencia en el crecimiento de plántulas de tomate (Lycopersicon esculentum Mill). Revista Chapingo. Serie horticultura, 14: 33-39

Vivanco, M. (2005). Muestreo estadístico. Diseño y aplicaciones. 1st ed. Santiago de Chile: Editorial Universitaria. 210p. 


\title{
Quality parameters of pink pepper seeds as sustainability indicators
}

\author{
Parámetros de calidad de las semillas de pimienta-rosa como indicadores \\ de sostenibilidad.
}

Aline Nahanna Carneiro Rodrigues¹; Gilmara Pires de Moura Palermo²; Madelon Rodrigues Sá Braz³; Tiago Böer Breier

\begin{abstract}
ARTICLE DATA
1 Researcher, Engenheira Florestal, Universidade Federal Rural do Rio de Janeiro. Rio de Janeiro, Brasil, aline. rodrigues@rjo.incra.gov.br

2 Professor, Dr. Universidade Federal Rural do Rio de Janeiro, Rio de Janeiro, Brasil, gilpalermo@hotmail.com

3 Professor, Dr. Universidade Federal Rural do Rio de Janeiro, Rio de Janeiro, Brasil, madelonsa@hotmail.com

4 Professor, Dr. Universidade Federal Rural do Rio de Janeiro, Rio de Janeiro, Brasil, tiagobreier@gmail.com
\end{abstract}

Cite: Rodrigues, A. N. C.; Palermo, G. P. M.; Braz, M. R. S.; Breier, T. B. (2020). Quality parameters of pink pepper seeds as sustainability indicators. Revista de Ciencias Agrícolas. 37(2): 27-39.

doi: https://doi.org/10.22267/rcia.203702.135

Received: September 302019 Accepted: December 172020

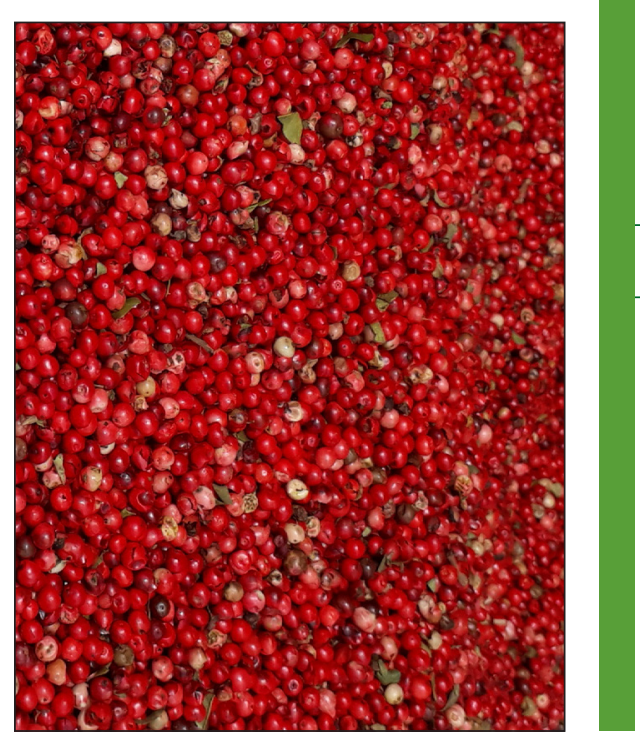

The poor management and marketing of rose pepper (Schinus terebinthifolius Raddi) in São Pedro D’Aldeia - RJ called the local governments' attention to adopt measures that favor the value chain, increase income, train rural producers, and launch the first Simplified Forest Management Plan. All of this, to authorize the sustainable management of this species. This study aimed to evaluate the quality parameters of pink pepper as sustainability indicators. The following was measured: the moisture content, purity, uniformity in the sieve, and the weight of one thousand seeds in samples obtained from three different batches. The germination test was only carried out for samples from lot 3. The results showed that the high moisture content of the seeds (22.99\%) has a negative effect on their quality, facilitating the action of spoilage organisms. The degree of purity was satisfactory (97.1\%). The seeds from lot 1 were larger and more uniform than the seeds from lots 2 and 3. Only lot 1 presented the weight of seeds compatible with that required by MAPA. The germination rate was $72 \%$, which did not vary between seeds of different sizes. The settlement's extractive activity is moving towards sustainability, which can be improved by incorporating good seed collection, processing and storage practices.

Keywords: S. terebinthifolius; seed analysis; rural settlement; sustainable development; extractivism.

\section{RESUMEN}

El inadecuado manejo y la comercialización de la pimienta-rosa (Schinus terebinthifolius Raddi) en São Pedro D’Aldeia - RJ, llamó la atención de los gobiernos locales sobre la adopción de medidas que favorezcan la organización de la cadena de valor; generación de ingreso; capacitación de productores rurales y la elaboración del primer Plan de Manejo Forestal Simplificado para autorizar el manejo sustentable de la especie. Este estudio tuvo como objetivo evaluar los parámetros de calidad de la pimienta-rosa como indicadores de sostenibilidad. Para ello se determinó: el contenido de humedad, pureza, 
uniformidad en tamiz y peso de mil semillas en muestras obtenidas de tres lotes diferentes. La prueba de germinación solo se realizó para muestras del lote 3. Los resultados mostraron que el alto contenido de humedad de las semillas $(22,99 \%)$ tiene un efecto negativo en su calidad, facilitando la acción de organismos deterioradores. El grado de pureza fue satisfactorio $(97,1 \%)$. Las semillas del lote 1 fueron más grandes y uniformes en comparación con las semillas de los lotes 2 y 3 . Solo el lote 1 presentó un peso de semillas compatibles con lo requerido por MAPA. La tasa de germinación fue del 72\%, la cual no varió entre semillas de diferentes tamaños. La actividad extractivita en el asentamiento avanza hacia la sostenibilidad, la cual se puede mejorar mediante la incorporación de buenas prácticas de recolección, procesamiento y almacenamiento de semillas.

Palabras clave: S. terebinthifolius; análisis de semillas; asentamiento rural; desarrollo sostenible; extractivismo.

\section{INTRODUCTION}

Pink pepper (Schinus terebinthifolius Raddi) is an Anacardiaceae native to Brazil. It is a helophyte plant that also grows in dry and poor soils. Its crown is rounded, and its trunk is tortuous with thick and cracked bark. It occurs from Pernambuco to Santa Catarina and Mato Grosso do Sul and, it is found in several vegetation formations, from the sandbank to the high semi-deciduous and rain forests (Neves et al., 2016).

The pepper exploitation in Rio de Janeiro began to intensify in late 1990's and has been growing in recent years with the main extractive activity in the region. The informal pink pepper market was evidenced around the 2000s due to the increase in the cargo seizures occurrences. In the state's scale of participation in exploring the species, Rio de Janeiro occupied first place, representing $42 \%$ of the market with 640 tons per harvest (Gomes et al., 2013).

Due to lack of legislation knowledge, management techniques for exploration and security, the collectors of Baixada Litorânea, especially those from the Ademar Moreira settelment farmers, acted without structuring the productive segment without knowledge about pruning techniques, fruit selection, processing, and storage.

Currently, the legal basis for the exploitation of pink pepper is provided by Federal Law n. 11.428/2006
(Presidência da República de Brasil, 2006) which requires an authorization instrument from the competent state or federal agency for the cutting, suppression, and commercial exploitation of trees in the Mata Atlântica biome, and the Resolution No. 124/2015 from INEA ch. V, art. 26 (INEA, 2015) which state the norms for Non-Timber Forest Products. If their exploration is carried out for commercial purposes, it will be considered Sustainable Forest Management and will depend on the presentation and approval of a Simplified Forest Management Plan for the forest species that will be exploited commercially.

In 2017, the SENAR-RJ (Serviço Nacional de Aprendizagem Rural-RJ) promoted the settlement farmers involved in extractives courses on pink pepper management and acceptable practices. Moreover, INEA contemplated the Settlement's Farmers Association with the first environmental authorization for species' sustainable forest management in May 2018, developed by the working team Aroeira (INEA, 2018). The three spheres of government acted together and actively elaborated the management plan, training and organizing of farmers and giving technical assistance.

The non-timber simplified forest management plan was first developed in the RJ state. It includes the exploitation of pink pepper inside the Ademar Moreira Settlement in collective legal reserve, 
regularizing this farmer's traditional activity. The authorization recognizes the Natural resources, sustainable economic exploitation importance for income generation in rural communities, and environmental conservation.

Inadequate harvesting and processing can result in a rapid deterioration and fruit quality loss, negatively affecting production sustainability. The lack of seeds quality can be expressed in the low uniformity index, degree of maturity, insects and fungi that hinder better yield in harvesting and marketing with a loss of market value for sale. The problem can be solved through better dissemination and technology transfer to harverst fruits appropriately and apply conservation or pre-processing techniques (Gomes et al., 2013).

In this way, the incentive for rural producers' technical qualificationconcerning acceptablepink pepper management practices is in accordance with two Sustainable Development Goals (SDG) established by United Nations (2015):

Goal n. 12: Ensure sustainable production and consumption patterns, aiming to contribute to 2030 agenda, achieving sustainable management and efficient use of natural resources and ensuring that people have relevant information for developing sustainable eco-friendly lifestyles; and

Goal n. 15: To protect, recover and promote the use of terrestrial ecosystems, managing forests, combating desertification, reserving land degradation and stopping biodiversity loss.

The low quality of the product directly interferes with market competitiveness and profit, making extractive activity unsustainable. Therefore, this work aims to analyze the quality of pink pepper seeds and guide producers to adopt appropriate techniques for collecting, conserving and, storing seeds; to increase the extractive activity's quality and sustainability.

\section{MATERIALS AND METHODS}

Characterization of the study area. Seed collection was carried out at the federal settlement Ademar Moreira (coordinates -22.713908, -42.108458), São Pedro D’Aldeia / RJ. The climate is tropical, with an average annual temperature ranging between 24 and $28^{\circ} \mathrm{C}$. November and December are the months with the highest rainfall, while June and July are the driest.

The settlement consists of 21 families. Sixteen are involved in the extraction of pink pepper, and part of the average family income comes from the sale of pink pepper.

The settlement comprises 487.68ha inserted in the Atlantic Forest biome. Of them, 180.37ha are intended to harvest pink pepper. However, each lot has an average of 20 individuals in management's potential (INEA, 2018).

Seed collection and analysis. The collection of seed samples from Lots 1 and 2 was carried out in loco. The samples were acquired from a bouquet of seeds from different pink pepper trees, harvested in May/2018 and June/2018. The sample from Lot 3, taken in May 2019, was acquired at a bioeconomy event (Green Rio), directly from Ademar Moreira settlement producers.

From each lot, samples composed of pink pepper seeds of adequate size for the tests and in similar proportions were obtained to guarantee uniform and accurate results in the analyses. The composed samples were taken at random and manually removed from the lots, each weighing approximately $1.000 \mathrm{~g}$.

The samples were stored in individual packages of transparent and impermeable plastic, identified; 
according to the lot they were collected. Subsequently, they were adequately packaged to avoid damage during transport, free of excess heat, humidity, and contamination. They were immediately sent to the Laboratory of Reproductive Biology and Conservation of Tree Species (LACON) in the Department of Silviculture/Forest Institute/ UFRRJ.

The procedures for analyzing the quality of pink pepper seeds were performed based on the "RAS - Rules for Seed Analysis" (MAPA, 2009 and MAPA, 2013), and the parameters determined were purity analysis; moisture content; uniformity in a sieve, the weight of a thousand seeds and germination and vigor test.

Purity analysis. Working samples of approximately $100 \mathrm{~g}$ were used; after weighing were placed on a smooth white surface. Then, the pure seeds. Other seeds and inert materials were separated manually and weighed individually on a scale with a precision of 0.0001 as described in the RAS (MAPA, 2009). The percentages were based on the sum of the component weights.

Determination of moisture content. The moisture content of the seeds was determined by the greenhouse method at $105 \pm 3^{\circ} \mathrm{C}$. Initially, from each lot, two $5 \mathrm{~g}$ subsamples were extracted from the $100 \mathrm{~g}$ working sample used in the purity test. The subsamples were initially placed in an aluminum crucible and weighed on a $0.001 \mathrm{~g}$ precision scale to determine the seeds' moisture content. Subsequently, they were sent to the greenhouse at $105 \pm 3^{\circ} \mathrm{C}$ and maintained for 24 hours. After the drying period, the subsamples were removed from the greenhouse, covered, and placed in a desiccator until cool. After being cold, they were weighed again, and the moisture content was determined based on the formula described in the RAS (MAPA, 2009).
Uniformity test (sieve retention). Two working samples of approximately $100 \mathrm{~g}$ of seeds from each lot were weighed, placed on a set of analysis sieves (tyler $3.5=5.6 \mathrm{~mm}$, tyler $4=4.75 \mathrm{~mm}$ and tyler $5.0=4.0 \mathrm{~mm}$ ), and the whole was shaken for one minute. The seeds retained in the sieves were separated, weighed and had their percentage calculated according to RAS (MAPA, 2009). Due to the ripe fruits of the pink pepper having an average of 4.0 to $5.5 \mathrm{~mm}$ in diameter, the seeds' percentages retained in the 5.66, 4.75 and $4.00 \mathrm{~mm}$ mesh sieves were considered.

Thousand seed weight. Eight repetitions of 100 seeds each, from each lot, were counted manually and at random. Then, the seeds of each repetition were placed in a petri dish and weighed. The result of the thousand seed weight test is the average weight of the repetitions of 100 seeds, multiplied by ten, according to RAS (MAPA, 2009).

Germination and vigor test. For the test, only the seed samples from Lot 3 (collected in May/2019) were used as they had shorter storage times. From this, 400 seeds retained in each sieve (Tyler 4 $4.75 \mathrm{~mm}$ and Tyler $5-4.0 \mathrm{~mm}$ ) were selected and divided into four repetitions of 100 . These seeds were soaked for 10 minutes in a neutral detergent solution at 5\% (5 drops of detergent per $100 \mathrm{ml}$ of distilled water); subsequently, the seeds were rinsed with distilled water and immersed in a $2 \%$ sodium hypochlorite solution for two minutes and washed again with distilled water. After asepsis, the seeds were distributed inside gearbox boxes, on two sheets of germintest paper previously sterilized in an autoclave. According to RAS, the paper was moistened with $4.5 \mathrm{~mL}$ of distilled water, an amount established based on the leaves' weight (paper weight $\times 3.0$ ). Then, the gearbox boxes with the seeds were placed in germination chambers (BOD) at a constant temperature of $25^{\circ} \mathrm{C}$ for 21 days. 
The germination test was evaluated three times, every 7 days until the $21^{\text {st }}$ day, by counting the formation of normal, abnormal seedlings, primary root emission, dormant and dead seeds as proposed by MAPA (2009) and MAPA (2013). Germinated seedlings were considered normal seedlings. The result of the germinated seedlings was expressed as a percentage $(\mathrm{G} \%)$, and the count of the number of seedlings germinated in the first seven days was used to analyze the vigor of the seeds.

Sustainability assessment. A scale of 1 to 3 was used to classify the seeds' quality parameters; based on scientific research results (bibliographic review) and normative instructions from
MAPA. Grade 3 is related to high sustainability, grade 2 to medium sustainability and grade 1 to low sustainability (Table 1).

Statistical analysis. The data obtained were analyzed using a statistical package STATISTICA 7.0. The experimental design used was completely randomized. The t-test was performed for the germination and vigor test to check if the differences between treatments are significant at the level of $5 \%$ significance (depending on the mesh); moreover, analysis of variance (ANOVA) and comparison between means by the Tukey test for the parameters moisture content, thousand seeds weight and uniformity in a sieve.

Table 1. Degree of sustainability based on seed quality parameters.

\begin{tabular}{|c|c|c|c|}
\hline \multicolumn{2}{|c|}{ Parameters } & \multirow{2}{*}{$\begin{array}{c}\begin{array}{c}\text { Sustainability } \\
\text { Degree }\end{array} \\
3\end{array}$} & \multirow{2}{*}{$\begin{array}{l}\text { Bibliographic references } \\
\text { for assigning grades }\end{array}$} \\
\hline \multirow{3}{*}{ Moisture Content } & $<12 \%$ & & \\
\hline & $12 \%$ a $20 \%$ & 2 & \multirow{2}{*}{$\begin{array}{l}\text { (Medeiros e Zanon, 1998) } \\
\text { e (Oliveira et al. 2018) }\end{array}$} \\
\hline & $>20 \%$ & 1 & \\
\hline \multirow{3}{*}{ Purity } & $>97 \%$ & 3 & \multirow{3}{*}{$\begin{array}{l}\text { Normative Instruction } \\
\text { MAPA } 45 \text { (2013) }\end{array}$} \\
\hline & $97 \%$ a $96 \%$ & 2 & \\
\hline & $<96 \%$ & 1 & \\
\hline \multirow{3}{*}{ Uniformity in Sieve } & High* & 3 & \multirow{3}{*}{$\begin{array}{l}\text { Carvalho and Nakagawa } \\
\text { (2000); Ponce et al. (2019) } \\
\text { e Rossi et al. (2017) }\end{array}$} \\
\hline & Medium** & 2 & \\
\hline & Low $^{* * *}$ & 1 & \\
\hline \multirow{3}{*}{$\begin{array}{c}\text { Thousand Seeds } \\
\text { Weight (seeds/Kg) }\end{array}$} & 37,000 a 44,000 & 3 & \multirow{3}{*}{$\begin{array}{l}\text { Normative Instruction } \\
\text { MAPA } 45 \text { (2013) }\end{array}$} \\
\hline & 44,001 a 45,599 & 2 & \\
\hline & $>46,000$ & 1 & \\
\hline \multirow{3}{*}{$\begin{array}{c}\text { Germination and } \\
\text { Vigor }\end{array}$} & $>80 \%$ & 3 & \multirow{3}{*}{$\begin{array}{l}\text { Normative Instruction } \\
\text { MAPA } 45 \text { (2013) }\end{array}$} \\
\hline & $80 \%$ a $60 \%$ & 2 & \\
\hline & $<60 \%$ & 1 & \\
\hline
\end{tabular}

${ }^{*}$ High uniformity refers to $100 \%$ of the seeds retained in the $5.66 \mathrm{~mm}$ and $4.75 \mathrm{~mm}$ mesh sieve. ${ }^{* *}$ Medium uniformity refers to more than $40 \%$ of the seeds retained in the $4.75 \mathrm{~mm}$ mesh sieve. ${ }^{* * *}$ Low uniformity refers to more than $40 \%$ of the seeds retained in the $4.0 \mathrm{~mm}$ sieve. 


\section{RESULTS AND DISCUSSION}

Purity analysis. According to the Normative Instruction 45 MAPA (2013), which establishes identity and quality standards for the production and commercialization of seeds, the analyzes for pink pepper seeds must present a satisfactory result of a minimum purity of $97 \%$. Thus, it can be seen that Lots 2 and 3 presented a high percentage of purity according to the determined standards. It is greater than $97 \%$, while Lot 1 presented $94.2 \%$ purity (Table 2 ).

The presence; and the number of impurities present in a seed lot are related to post-harvest procedures. The reduced amount of impurities in the samples corresponding to Lots 2 and 3 indicates that the producers performed a good manual cleaning (scavenging), adding value to the product and increasing the production sustainability.

Moisture content. The average values of moisture content obtained for Lots 1, 2 and 3 were $21.63 \%$, $20.75 \%$ and $26.60 \%$, respectively (Table 3 ).

The high moisture content observed in the lots of pink pepper seeds studied it may have occurred due to its inadequate drying, in the post-harvest phase. However, for future harvests, the seeds will be dehydrated in a greenhouse at $45^{\circ} \mathrm{C}$, until the moisture content of $12 \%$ is reached, allowing the maintenance of their quality for a longer period.

Table 2. Percentage of purity of pink pepper seeds (Lots 1, 2 and 3).

\begin{tabular}{ccccccc}
\hline Lot & $\begin{array}{c}\text { Initial weight } \\
\text { (g) }\end{array}$ & $\begin{array}{c}\text { Pure seeds } \\
\text { (g) }\end{array}$ & $\begin{array}{c}\text { Other seeds } \\
\text { (g) }\end{array}$ & $\begin{array}{c}\text { Inert material } \\
\text { (g) }\end{array}$ & $\begin{array}{c}\text { Impurities } \\
(\mathbf{\%})\end{array}$ & $\begin{array}{c}\text { Purity } \\
\text { (\%) }\end{array}$ \\
\hline $\mathbf{1}$ & 128.1 & 123.5 & 0.0 & 4.5 & 5.8 & 94.2 \\
$\mathbf{2}$ & 113.0 & 110.7 & 0.0 & 2.4 & 2.7 & 97.3 \\
$\mathbf{3}$ & 115.4 & 114.4 & 0.0 & 0.0 & 1 & 99.9 \\
\hline
\end{tabular}

Table 3. Moisture content of pink pepper seeds (Lots 1, 2 and 3).

\begin{tabular}{|c|c|c|c|c|c|c|c|}
\hline Crucible & Lot & $\begin{array}{l}\text { Tare } \\
\text { (g) }\end{array}$ & $\begin{array}{l}\mathrm{Pu} \\
\text { (g) }\end{array}$ & $\begin{array}{l}\text { Ps } \\
\text { (g) }\end{array}$ & $\begin{array}{c}\text { U } \\
(\%)\end{array}$ & $\begin{array}{c}\text { Mean moisture } \\
\text { content } \\
(\%)\end{array}$ & $\begin{array}{l}\text { Total means } \\
\text { moisture content } \\
(\%) / \mathrm{CV}^{*}\end{array}$ \\
\hline 19 & 1 & 27.04 & 32.46 & 31.27 & 21.92 & \multirow{2}{*}{$21.63 \mathrm{~A}$} & \multirow{6}{*}{$\begin{array}{c}22.99 \\
12.78^{*}\end{array}$} \\
\hline 25 & 1 & 25.96 & 31.02 & 29.94 & 21.33 & & \\
\hline 6 & 2 & 28.55 & 33.75 & 32.74 & 19.47 & \multirow{2}{*}{$20.75 \mathrm{~A}$} & \\
\hline 40 & 2 & 36.80 & 41.97 & 40.83 & 22.04 & & \\
\hline 44 & 3 & 43.7 & 49.30 & 47.8 & 26.8 & \multirow{2}{*}{$26.60 \mathrm{~B}$} & \\
\hline 16 & 3 & 39.9 & 45.20 & 43.8 & 26.4 & & \\
\hline
\end{tabular}

$\mathrm{Pu}$ (Wet weight) Ps (Dry weight) U (Moisture percentage) and CV* (Coefficient of variation). Averages followed by the same letter do not differ statistically from each other by the Tukey test at $5 \%$ significance. 
Neves et al. (2016) considers that pink pepper seeds can be stored at $12.6 \%$ humidity for up to five months in the environment without affecting their quality as long as they are packed in a paper bag. However, pink pepper seeds have an orthodox behavior; they resist drying to low values, around 5 to $7 \%$, and can be stored with a low moisture and temperature content, maintaining their viability for a longer period.

Uniformity test (sieve retention). The result shows that $5.66,4.75$ and $4.00 \mathrm{~mm}$ mesh sieve retained 1.67, 49.69 and $37.80 \%$ of the pink pepper seeds, respectively (Figure 1).

Although there is less retention in the sieve with a mesh of $5.66 \mathrm{~mm}(1.67 \%)$ and $4.0 \mathrm{~mm}(37.80 \%)$, the differences were significant and may assist in decision-making about product marketing. On the other hand, larger and more uniform seeds may be sold in natura at a higher price. Instead of being sold at a lower price, the smaller seeds may be used to produce essential oils, adding value to the product.

\section{Sieve Retention}

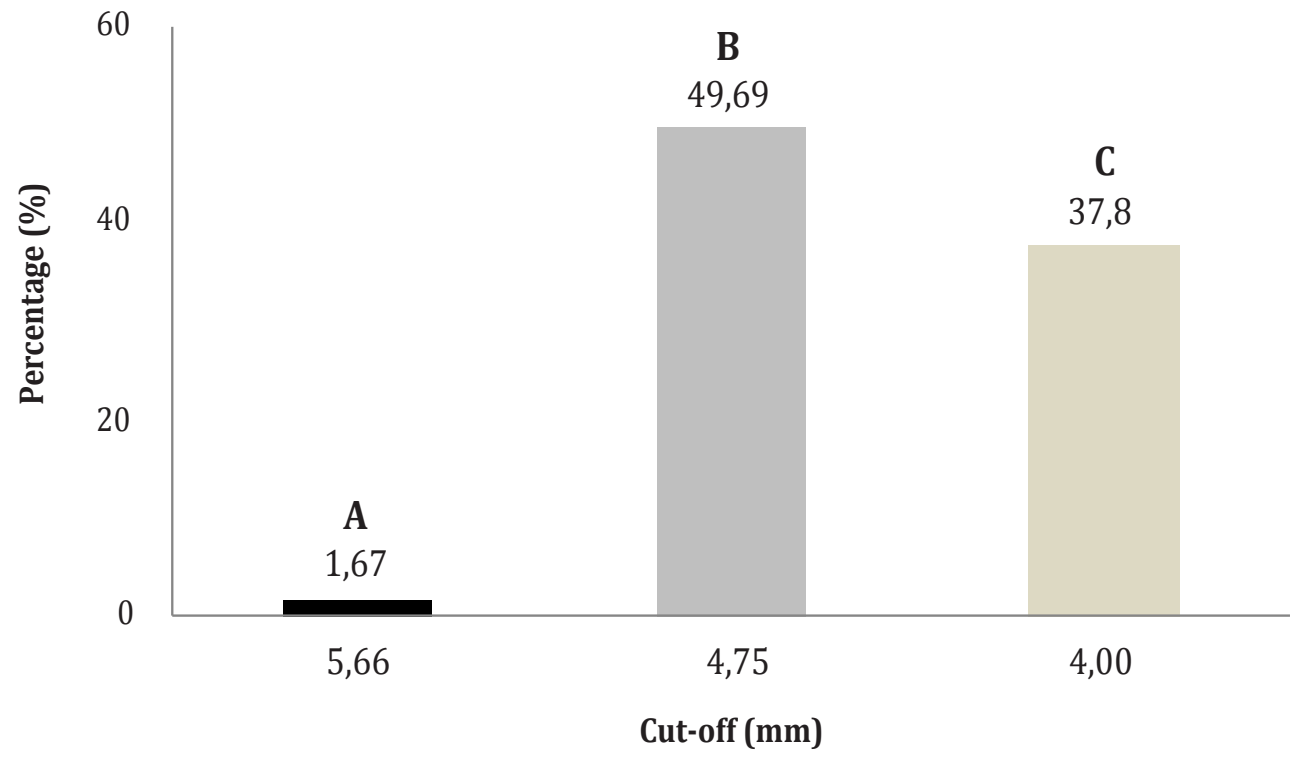

Figure 1. Percentage of seeds retained in a sieve of different meshes (mm). Averages followed by the same letter do not differ at $5 \%$ significance using the Tukey test.

No statistical differences were observed between lots for retention in 3.5 tyler sieves $(5.66 \mathrm{~mm})$. It is observed that the values found for Lots 1,2 and 3 are similar (Figure 2).

For the 4 Tyler sieve $(4.75 \mathrm{~mm})$, it is observed that there were differences between lots, with greater retention of seeds from Lot 1 when compared to Lots 2 and 3. The results obtained indicate Lot 1 presents more uniform seeds, bigger dimensions and better appearance, achieving a better quality standard; than Lots 2 and 3 (Figure 3). 


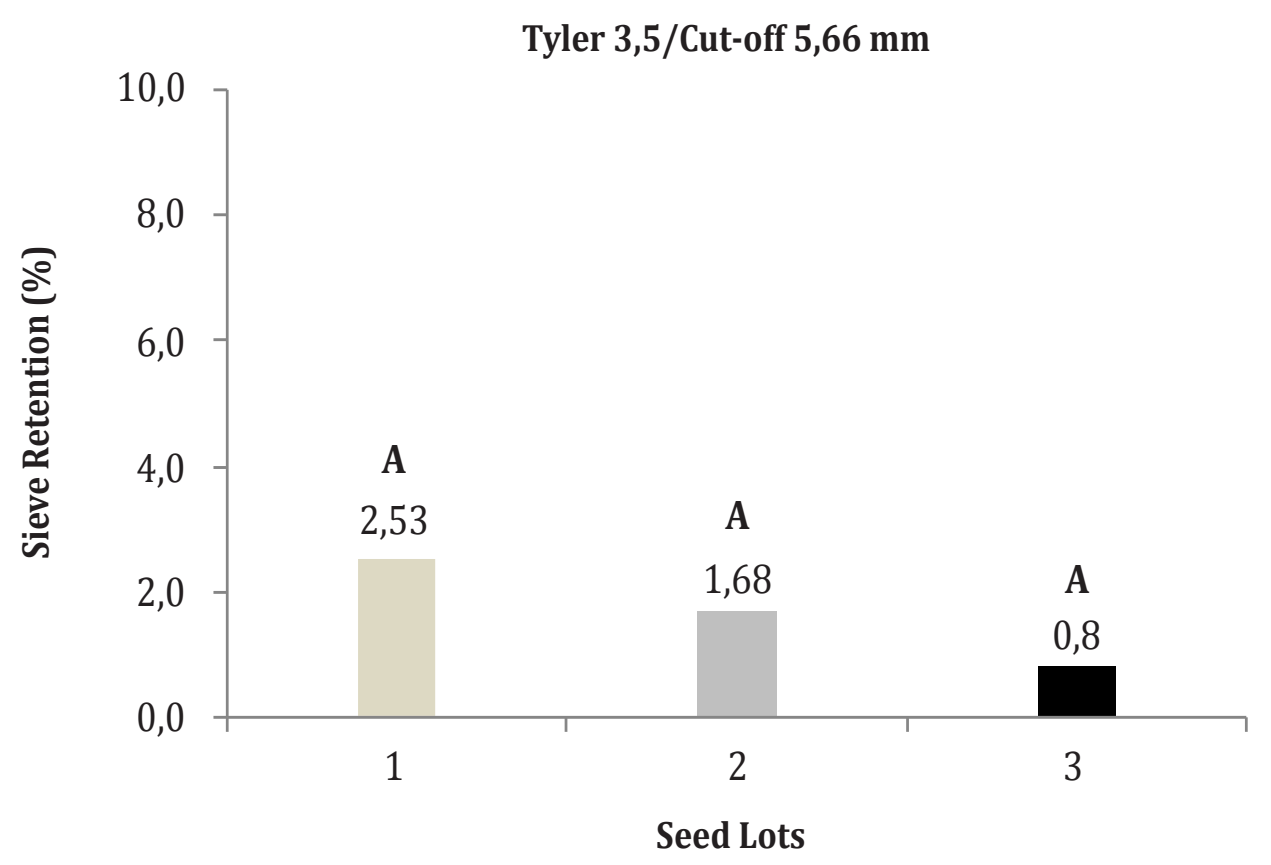

Figure 2. Percentage of seeds retained between lots, for 3.5 Tyler sieve, $5.66 \mathrm{~mm}$ mesh. Averages followed by the same letter do not differ at $5 \%$ significance using the Tukey test.

\section{Tyler 4/Cut-off 4,75 mm}

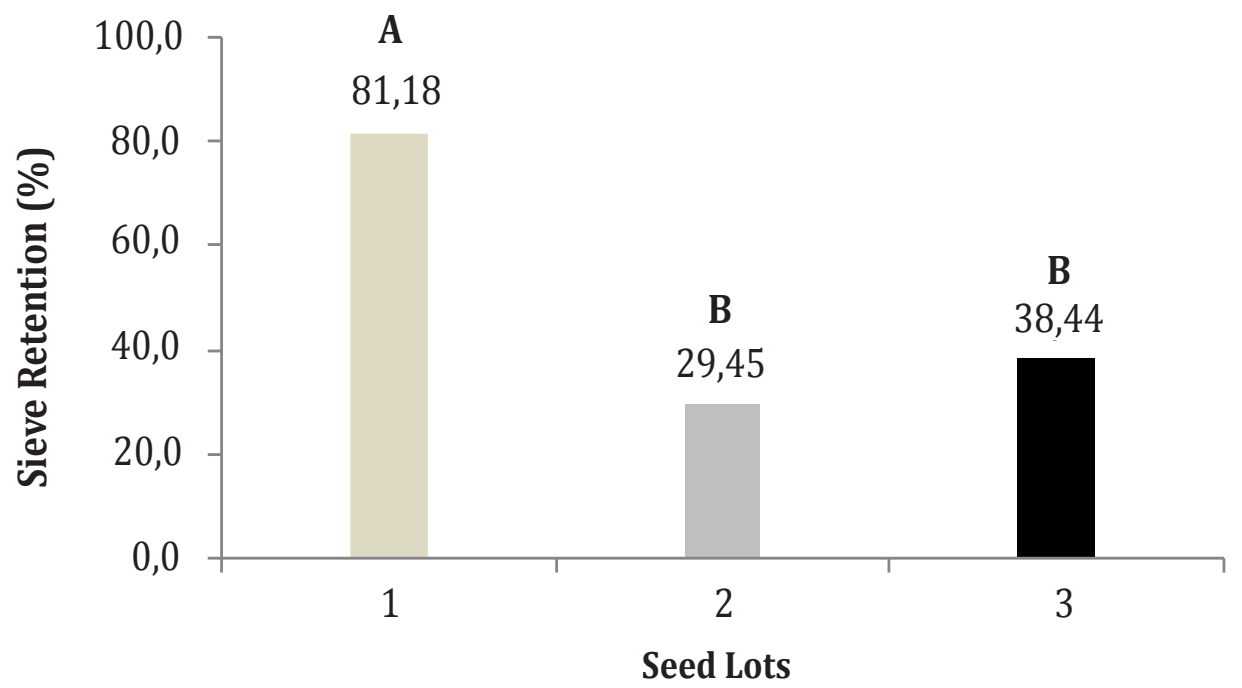

Figure 3. Percentage of seeds retained between lots, for 4 Tyler sieve, $4.75 \mathrm{~mm}$ mesh. Averages followed by the same letter do not differ at $5 \%$ significance using the Tukey test. 
As for the 5 Tyler sieve $(4.00 \mathrm{~mm})$, there was greater retention of seeds from Lots 2 and 3, indicating that these lots are smaller and can be classified for commercialization in a lower quality standard than Lot 1, (Figure 4).
Thousand seed weight. It is observed that there are significant differences at the level of $5 \%$ of significance between the lots for the average weight of a thousand seeds (Table 4).

\section{Tyler5/Cut-off 4 mm}

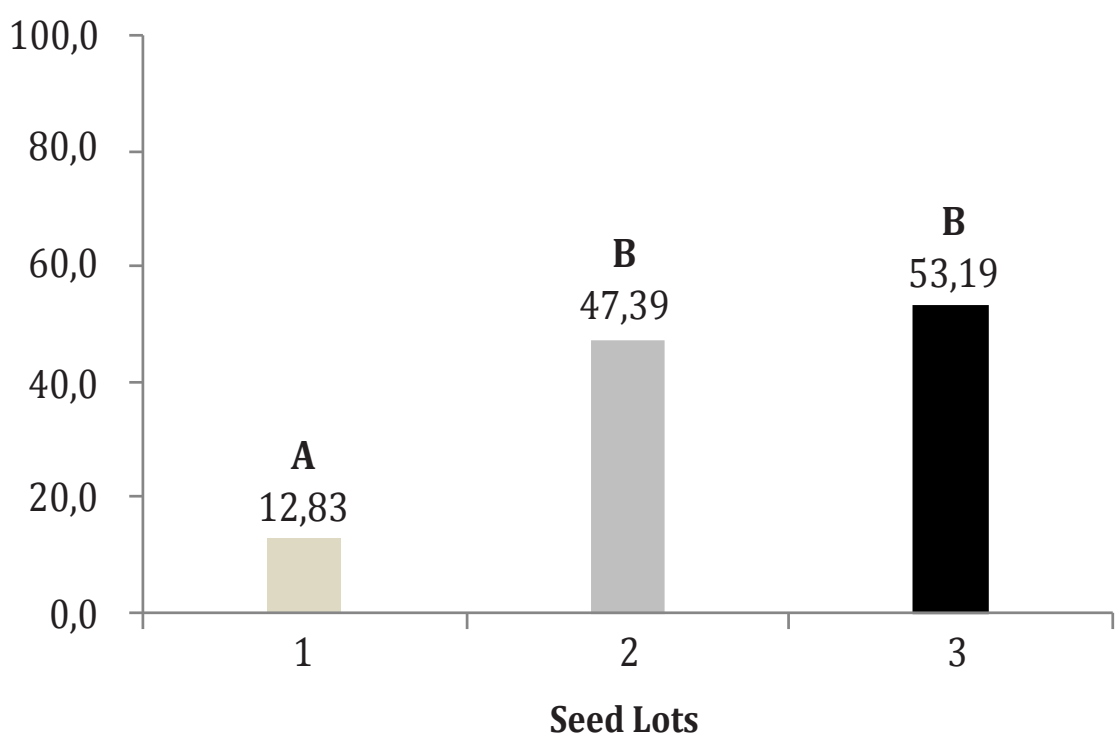

Figure 4. Percentage of seeds retained between lots, for 5 Tyler sieve, $4.0 \mathrm{~mm}$ mesh. Averages followed by the same letter do not differ at $5 \%$ significance using the Tukey test.

Table 4. Results of thousand seed weight tests (Lots 1, 2 and 3).

\begin{tabular}{cccc}
\hline \multirow{2}{*}{ Repetition } & Lot 1 & Lot 2 & Lot 3 \\
\cline { 2 - 4 } & Net weight (g) & Net weight (g) & Net weight (g) \\
\hline 1 & 2.68 & 2.23 & 2.32 \\
2 & 2.66 & 2.17 & 2.29 \\
3 & 2.72 & 2.34 & 2.15 \\
4 & 2.62 & 2.05 & 2.30 \\
5 & 2.20 & 2.01 & 2.32 \\
6 & 2.38 & 2.11 & 2.29 \\
7 & 2.51 & 2.16 & 2.30 \\
8 & 2.45 & 2.13 & 2.30 \\
\hline Seed average & $\mathbf{2 . 5 3}$ & $\mathbf{2 . 1 5}$ & $\mathbf{2 . 2 8}$ \\
\hline Thousand seed weight & $\mathbf{2 5 . 2 7 ~ A}$ & $\mathbf{2 1 . 5 1 ~ B}$ & $\mathbf{2 2 . 8 3 ~ B}$ \\
\hline
\end{tabular}

Averages followed by the same letter do not differ at $5 \%$ significance using the Tukey test. 
This analysis indicates that Lot s 1 seed are larger and have better physical quality than Lots 2 and 3 . This difference may be related to the seeds' maturity, health, and water content (MAPA, 2009), or the endosperm's size, and consequently the number of reserves in the seeds (Ponce et al., 2019).

Germination and vigor test. It is observed that the average germination index is similar between the seeds retained in the $4.75 \mathrm{~mm}$ and $4.0 \mathrm{~mm}$ mesh sieve (Table 5).

The performance of seedlings in the first germination count allows determining the seed's lot quality as performed in this study, by comparing and identifying seeds with a greater or lesser probability of establishing themselves in the field (Guedes et al., 2015). Thus, the results obtained in this study indicate that the seeds present, on average, a high total germinative index $(G=72 \%)$. However, in the first seven days, this value was low, around 20\%, which can be an obstacle in establishing seedlings in the field.

Sustainability assessment. The purity indicator reached an average of grade 3 - highly sustainable; the indicators insect incidence, uniformity in sieve, germination, and vigor reached grade 2 - medium sustainability; and the moisture content indicator reached grade 1 - not very sustainable, (Figure 5).

Table 5. The first, second, and third seedling count, in days, and total germination index $(G)$ of pink pepper seeds retained in the 4.75 and $4.0 \mathrm{~mm}$ sieves.

\begin{tabular}{|c|c|c|c|c|c|}
\hline \multirow{2}{*}{ Tyler/Mesh } & \multirow{2}{*}{ Repetition } & \multicolumn{4}{|c|}{ Number of normal seedlings } \\
\hline & & 7 Days & 14 Days & 21 Days & $\mathrm{G}(\%)$ \\
\hline \multirow{5}{*}{$4 / 4.75 \mathrm{~mm}$} & 1 & 19 & 48 & 2 & 69 \\
\hline & 2 & 19 & 45 & 1 & 65 \\
\hline & 3 & 25 & 49 & 2 & 76 \\
\hline & 4 & 24 & 41 & 1 & 66 \\
\hline & Average & 22 & 46 & 2 & $69 \mathrm{~A}$ \\
\hline \multirow{5}{*}{$5 / 4.0 \mathrm{~mm}$} & 1 & 7 & 68 & 3 & 78 \\
\hline & 2 & 26 & 54 & 1 & 81 \\
\hline & 3 & 22 & 52 & 2 & 76 \\
\hline & 4 & 20 & 42 & 1 & 63 \\
\hline & Average & 19 & 54 & 2 & $75 \mathrm{~A}$ \\
\hline \multicolumn{2}{|c|}{ Total average } & 20 & 50 & 2 & 72 \\
\hline
\end{tabular}

G\% (Total Germination Index). Averages followed by the same letter do not differ at $5 \%$ significance using the $t$ test. 


\section{Sustainability assessment}

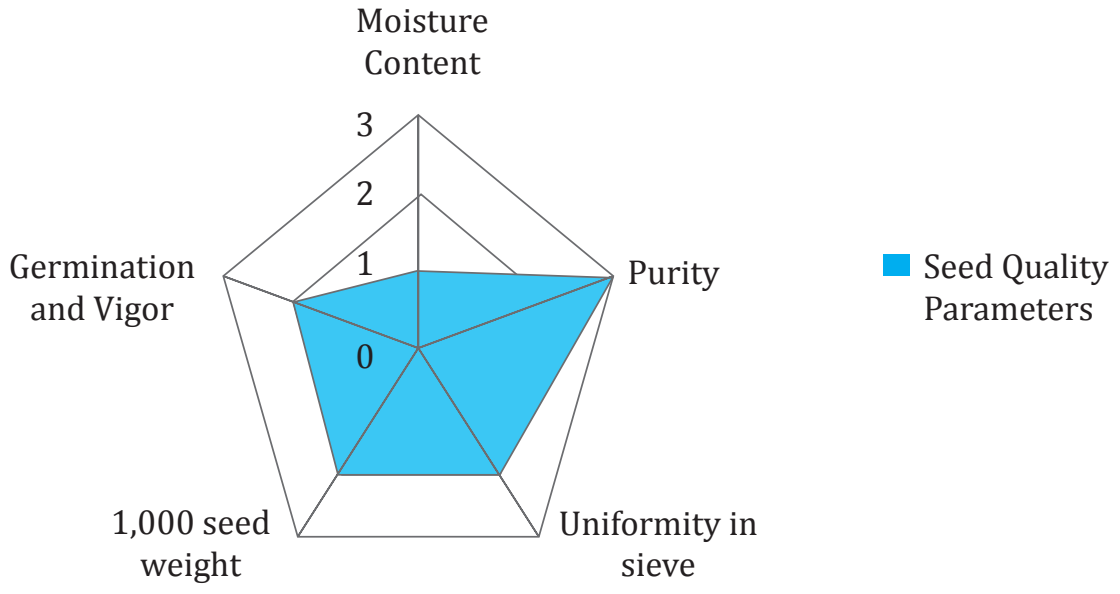

Figure 5. Sustainability assessment chart.

According to the sustainability assessment chart, it can be seen that the purity quality parameter was assigned a grade of 3 . The impurity removal procedure is performed efficiently in the postharvest, contributing to raising the physical and adding value to commercialized seeds.

Only one of the lots presented a satisfactory result in the weight test of a thousand seeds, as indicated by Normative Instruction \#45 of MAPA (2013). Therefore, in the sustainability assessment, this parameter was assigned to grade 2. The results presented point to the need to observe the seeds' health, the moisture content, and the favorable period for the harvest (degree of maturity) since the thousand seed weight may vary to these factors (MAPA, 2009).

Grade 2 was assigned to the uniformity parameter. This parameter varies widely, suggesting that the seeds should be separated by size. Degradation due to humidity and delay in the harvest period are factors to be observed. It may be related to the small size and low uniformity of the seeds. The classification of seeds by size will benefit the commercialization of the product as they can be commercialized by variable size and price.
The high moisture content found in pink pepper seeds is a weak point in the environmental, social, and economic sustainability of the Ademar Moreira settlement's extractivist activity. This characteristic leads to loss of seed quality as it interferes with the increase in the incidence of fungi and deterioration by insects; in addition, it contributes to the reduction of germination and vigor. The moisture content is a parameter that needs to be improved as it can decrease the natural longevity of the seeds. According to Souza et al. (2016), the environmental conditions affect the viability of the seeds; however, the moisture content is one of the factors that most interfere in the conservation of the physiological potential of the seeds. This parameter was assigned to grade 1 .

Regarding germination and vigor, Gomes et al. (2013) highlight that one of the biggest problems associated with the pink pepper stems extraction from the difficulty in maintaining genetically diverse populations to ensure good fruit production for use in both ecological and socioeconomic aspects. For the authors, the adequate storage of seeds contributes to the maintenance of germplasm banks and ensures the rescue of important genotypes for the seedlings 
production for commercial plantations and use in the recovery or restoration of degraded areas. Thus, the high moisture content interferes with germination and causes genetic losses for pink pepper.

Although pink pepper is a product that mostly affects the foreign market, because its production is practically exported to Europe, Asia, and the United States of America (Sodré, 2016). The seeds' collectors are not well paid; because most of the income goes to traders. Thus, the adoption of adequate practices for harvesting, processing and storing of seeds and new processing technologies can add value to the product in natura. For example, essential oilscan guarantee higher income for collectors and increase the sustainability of the pink pepper value chain in the Ademar Moreira settlement.

Conflict of interest: The authors declare that there is no conflict of interest.

\section{CONCLUSIONS}

Among the quality parameters analyzed, the degree of purity was high, but it is necessary to pay attention to the period of fruit maturation, seed size, and moisture content as they affect products' quality.

The best germinative index of the species occurs at 14 days after sowing, and it does not vary between seeds of different sizes. However, the high moisture content of seeds sold by producers (22.99\% on average) interferes with their quality and compromises production. In this way, the Ademar Moreira Settlement is moving towards the sustainability of the pink pepper extraction activity, but it is necessary to incorporate better practices for collecting, processing and storing seeds.

\section{BIBLIOGRAPHIC REFERENCES}

Presidência da República de Brasil. (2006). Lei no 11.428, de 22 de dezembro de 2006. Dispõe sobre a utilização e proteção da vegetação nativa do Bioma Mata Atlântica, e dá outras providências. Retrieved from https://url.gratis/Wz0Zh

Carvalho, N. M.; Nakagawa, J. (2000). Sementes: Ciência, tecnologia e produção. 4ํㅡ. ed. Jaboticabal: FUNEP. 588p.

Gomes, L. J.; Silva-Mann, R.; Mattos, P. P.; Rabbani, A. R. C. (2013). Pensando a biodiversidade: Aroeira (Schinus terebinthifolius Raddi.). São Cristóvão: UFS. 372p.

Guedes, R. S.; Alves, E. U.; Santos-Moura, S. S.; Galindo, E. A. (2015). Teste de comprimento de plântula na avaliação da qualidade fisiológica de sementes de Amburana cearensis (Allemão) A. C. Smith seeds. Semin. Cienc. Agrar. 36 (4): 2373-2382. doi: http:// dx.doi.org/10.5433/1679-0359.2015v36n4p2373

INEA - Instituto Estadual do Meio Ambiente. (2018). Boletim de serviço № 58. Retrieved from https:// cutt.ly/5ktaPM7B

INEA - Instituto Estadual do Meio Ambiente. (2015). Resolução INEA № 124. Dispõe sobre procedimentos e parâmetros técnicos para a exploração florestal sob regime de manejo florestal sustentável. Diário Oficial do Estado do Rio de Janeiro, Rio de Janeiro, № 183, p.15-17. Retrieved from https://cutt. ly/5ktaPM7

MAPA-Ministério Agricultura Pecuária eAbastecimento. (2013). Normative Instruction MAPA 45/2013. Retrieved from https://cutt.ly/zhCV5mG

MAPA - Ministério da Agricultura, Pecuária e Abastecimento. (2009). Regras para análise de sementes. Brasília: MAPA/ACS. 399p.

MAPA - Ministério da Agricultura, Pecuária e Abastecimento. (2013). Instruções para análises de sementes de espécies florestais. Brasília: MAPA. 98p.

Medeiros, A. C. S.; Zanon, A. (1998). Conservação de sementes de aroeira-vermelha (Schinus terebenthifolius Raddi). Boletim de Pesquisa Florestal 36: 11-20. 
Neves, E. J. M.; Santos, A. M.; Gomes, J. B. V.; Ruas, F. G.; Ventura, J. A. (2016). Cultivo da aroeira-vermelha (Schinus terebinthifolius Raddi) para produção de pimenta-rosa. Colombo: Embrapa Florestas. 24p.

Oliveira, F. T. G.; Vitória, R. Z.; Posse, S. C. P.; Arantes, S. D.; Schmildt, O.; Viana, A.; Malikouski, R. G.; Barros, B. L. A. (2018). Qualidade fisiológica de sementes de aroeira em função das condições de armazenamento. Nucleus. 15 (2): 567-574. doi: https://doi.org/10.3738/1982.2278.2959

Ponce, R. M.; Costa, D. S.; Lima,L. H. S.; Ibanhes Neto,H. F.; Takahashi, L. S. A. (2019). Tamanho da semente e potencial fisiológico de trigo sarraceno. Rev. Cient. Rural. 21 (2): 259-268. doi: https://doi. org/10.30945/rcr-v21i2.354

Rossi, R. F.; Cavariani, C.; França-Neto, J. B. (2017). Vigor de sementes, população de plantas e desempenho agronômico de soja. Rev. Cienc. Agrar. 60(3): 215222. doi: http://dx.doi.org/10.4322/rca.2239

Sodré, E. (2016). São Mateus, maior produtor de pimenta-rosa do mundo. Retrieved from https:// cutt.ly/JhCNHf0

Souza, P. P.; Motoike, S. Y.; Carvalho, M.; Kuki, K. N.; Borges-Lima, E. E.; Silva, A. M. (2016). Storage on the vigor and viability of macauba seeds from two provenances of Minas Gerais State. Cienc. Rural. 46 (11): 1932-1937. doi: http://dx.doi. org/10.1590/0103-8478cr20150848

United Nations. (2015). Transforming our world: The 2030 Agenda for Sustainable Development. Retrieved from https://cutt.ly/hkBeg4n 


\title{
Physicochemical properties and acceptability of three formulations containing fava bean, quinoa and corn flour extrudates
}

\author{
Propiedades fisicoquímicas y aceptabilidad de tres mezclas alimenticias a \\ base de harinas extruidas de haba, quinua y maíz.
}

Frank F. Velásquez-Barreto ${ }^{1}$; Edson E. Ramirez-Tixe²; Mariana D. Salazar-Irrazabal ${ }^{3}$; Elias Salazar-Silvestre ${ }^{4}$

\begin{tabular}{l}
\hline \multicolumn{2}{c}{ ARTICLE DATA } \\
\hline 1 Professor, M.Sc. Universidad Nacional Autónoma de \\
Chota, Chota-Cajamarca, Perú, frankervba@hotmail.com \\
2 M.Sc. Universidad Nacional Autónoma de Chota, Chota- \\
Cajamarca, Perú, erth-335@hotmail.com \\
3 Agroindustrial Engineer, Universidad Nacional de \\
Huancavelica, Acobamba-Huancavelica, Perú, \\
salimard_3101@hotmail.com \\
4 Agroindustrial Engineer, Universidad Nacional de \\
Huancavelica, Acobamba-Huancavelica, Perú, elias_el_ \\
unico@hotmail.com \\
\hline
\end{tabular}

Cite: Velásquez-Barreto, F.; Ramirez-Tixe, E.; SalazarIrrazabal, M.; Salazar-Silvestre, E. (2020). Physicochemical properties and acceptability of three formulations containing fava bean, quinoa, and corn flour extrudates. Revista de Ciencias Agrícolas. 37 (2): 40-48.

doi: https://doi.org/10.22267/rcia.203702.136

Received: August 32019.

Accepted: Decembre 122020.

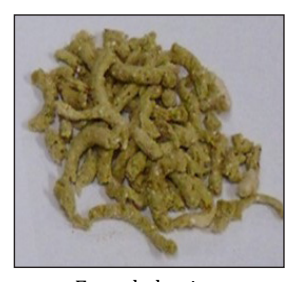

Extruded quinoa

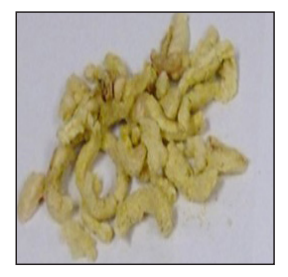

Extruded bean

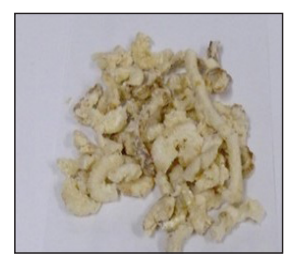

Extruded corn

\section{ABSTRACT}

Andean grains, widely distributed in the high areas of the Andean Highlands, can help to reduce malnutrition owing to their high content of protein and balance of essential amino acids. Recently, their consumption has changed as they are increasingly used for instant food mixtures. However, a better design and formulation are necessary to maintain Andean grains' nutritional value and characteristics. In this study, we evaluated the physicochemical properties and acceptability of three formulations containing extruded corn (Zea mays L.), fava bean (Vicia faba L.), and quinoa (Chenopodium quinoa Willd) flours. Grain samples were collected from Choclococha, Acobamba, Huancavelica, Peru, and extruded at $95^{\circ} \mathrm{C}$. Subsequently, three flour formulations were prepared. The formulation comprising $30 \%$ fava bean flour, $58 \%$ quinoa flour, and $12 \%$ corn flour consisted of $18.64 \%$ protein, $4.87 \%$ fat, $8.4 \%$ humidity, $2.99 \%$ ash, and $62.44 \%$ carbohydrates. This formulation with the highest quinoa flour content presented the highest acceptability in terms of color odor and flavor, and the highest protein content and digestibility (72.6\%) of all analyzed formulations. Thermal analysis and pasting testing indicated that the formulation with the highest acceptability did not contain native starch; moreover, the proteins in this formulation were denatured.

Keywords: Chenopodium; acceptability; Andean foods; instant foods; food formulations.

\section{RESUMEN}

Los granos andinos se encuentran ampliamente distribuidos en las zonas altas de la cordillera de los andes y pueden ayudar a enfrentar la desnutrición debido a su alto contenido de proteínas y a su balance de aminoácidos. Actualmente, el consumo de estos granos ha cambiado y se ha incrementado el uso en forma de mezclas alimenticias instantáneas. Sin embargo, un buen diseño y formulación son necesarios con el fin de mantener su valor nutricional y características sensoriales de los granos andinos. En este estudio, se evaluó las propiedades fisicoquímicas aceptabilidad de tres formulaciones alimenticias a base de 
harinas extruidas de maíz (Zea mays L.), haba (Vicia faba L.) y quinua (Chenopodium quinoa Willd). Los granos fueron recolectados del centro poblado de Choclococha, Acobamba, Huancavelica, Perú y fueron extruidas a $95^{\circ} \mathrm{C}$. Posteriormente, tres formulaciones fueron preparadas. La mejor formulación (30\% de harina de haba, $58 \%$ de harina de quinua y $12 \%$ de harina de maíz) presentó un contenido de proteínas de 18,64\%; grasa de 4,87\%; humedad de 8,4\%; cenizas de 2,99\%; carbohidratos de $62,44 \%$. Esta formulación con el más alto contenido en quinua mostró la mayor aceptabilidad en relación al color, olor y sabor, además un alto contenido de proteína y digestibilidad (72,6\%). El análisis térmico y la prueba pasting indicaron que la formulación con la mayor aceptabilidad no mostró la presencia de almidón nativo, así mismo, las proteínas de esta formulación fueron desnaturalizadas.

Palabras clave: Chenopodium; aceptabilidad; alimentos andinos; comidas instantáneas; formulaciones alimenticias.

\section{INTRODUCTION}

Several new nutritional trends have focused on products with health benefits such as Andean legumes and seeds (Mendoza-Jiménez et al., 2018). Recent studies have confirmed that Andean products are benefit for health because they contain soluble and insoluble fibers, resistant starch, proteins with bioactive properties, and phenolic compounds. (Delgado-Andrade et al., 2016). Quinoa (Chenopodium quinoa Willd), an Andean grain from Peru and Bolivia's Andean areas, is an ancestral food owing to its nutritional qualities (Tovar-Hernández et al., 2017).

Quinoa is consumed as raw grain, cooked, or processed into flour, bakery products, porridges, drinks, and fermented products. The quinoa's nutritional value depends on its protein contents, dietary fiber, minerals, and polyunsaturated fats. The protein content of dry quinoa varies between 13.8 and 16.5\%; however, it has been reported to be $15 \%$ on average (USDA, 2015). Moreover, quinoa is a valuable food source (Filho et al., 2017). Corn (Zea mays L.) supplements a significant amount of sulfur amino acids to the human diet (Estrada et al., 2015). Miranda et al. (2015) reported that the corn's protein content was 8.80\%; therefore, corn is an important food source. Corn is used for bakery products and represents an alternative for gluten-intolerant consumers. Therefore, it is necessary to expand the quantity and quality of corn-based products for consumers who adopt a gluten-free diet (Estévez and Araya, 2016).

Fava beans (Vicia faba L.) are a significant crop and income source in Peru's Andean areas. Fava beans are rich in protein, carbohydrates, dietary fiber, lecithin, minerals, and secondary metabolites (Etemadi et al., 2018). The protein content of fava beans ranges between 20 and 41\%, and the main proteins in fava beans are globulins (79\%), albumins (7\%), and glutelins (7\%) (Sathya and Devi, 2018). Fava beans have traces of several antinutritional factors, such as phytates, tannins, proanthocyanidins, sucrose, condensed tannins, protease inhibitors, and alkaloids. They are easily degraded via heat treatment (Coda et al., 2015).

Extrusion is a thermomechanical process that can alter the structure of starch, cause gelatinization and change the structure of native starch, because of the pressure and temperature used during the process, increasing starch digestibility. Moreover, other polymers, such as proteins, can change their structural architecture and become denatured during extrusion, facilitating their rapid degradation by digestive enzymes (Jiangping et al., 2017).

A large number of extruded products are processed and sold; as example there are pasta, breakfast cereals, breadcrumbs, cookies, croutons, baby food, snacks, confectionery, chewing gum, textured vegetable proteins, modified starch, pet food, dry 
soups, and dry drink mixes. Flours or grains, are subjected to extrusion to obtain products with particular sensory characteristics and functional properties; such as water absorption, water solubility, oil absorption indices, expansion indices, apparent density, and mass viscosity (Alama et al., 2015).

Numerous Andean grains (legumes and cereals) can help to reduce malnutrition in impoverished Andean areas of Peru. For this, the Andean grains' adequate industrial transformation with high nutritional value and optimization of instant flour formulations (food mixes) is required to improve Andean residents' nutritional status. Therefore, in this study, we evaluated the physicochemical characteristics and acceptability of three food formulations comprising extruded corn, fava bean, and quinoa flours.

\section{MATERIALS AND METHODS}

Characterization of raw materials. Fava beans, quinoa, and corn were collected from Choclococha, Acobamba, Huancavelica, Peru located at 3383 masl. The following methods were used to analyze the chemical composition of raw materials and food formulations: UNE-EN ISO 5983-2 for protein, UNE 64021-1970 for fat, UNE 640151971 for humidity, UNE 64019-1971 for ashes, and NMX-F-090-1978 for fiber; carbohydrates were determined by difference. The pepsin digestibility of the extruded mixtures was determined using the NMX-Y-085-SCFI-2006 standard method.

Extrusion. Extrusion was performed at the Technological Experimental Center of the National University of Callao. First, 500g of sample (fava beans and corn) were milled in a stainless-steel disc mill to an average size of $5-6 \mathrm{~mm}$. The quinoa grains were not ground owing to their small size. The milled samples were conditioned to a humidity of $9.32 \%$. Extrusion was performed in a single screw extruder at $95^{\circ} \mathrm{C}$, and a retention time of $15 \mathrm{~s}$ was used for all runs. Subsequently, the extruded samples were milled again using a hammer mill and were sieved using a Tyler $\mathrm{N}^{\circ} 35$ mesh, and stored on Kraft paper.

Formulation. The extruded formulations met the standard for infants recommended by the Food and Agriculture Organization/ World Health Organization (FAO/WHO) (2016). The following formulations were prepared: formulation $1\left(\mathrm{~F}_{1}\right)$ : $38 \%$ extruded fava bean flour, 50\% extruded quinoa flour, and $12 \%$ extruded corn flour; formulation $2\left(\mathrm{~F}_{2}\right): 36 \%$ extruded fava bean flour, $52 \%$ extruded quinoa flour, and 12\% extruded corn flour; and formulation $3\left(\mathrm{~F}_{3}\right)$ : 30\% extruded fava bean flour, $58 \%$ extruded quinoa flour, and $12 \%$ extruded corn flour.

Sensory analysis. Sensory analysis at the San Francisco de Asís Educational Institution, Acobamba was carried out based on the guidelines by the Peruvian Technical Standards (2008) (ISO 4121, 2008). For this, samples of the three extruded formulations were added to hot water, and equal amounts of sugar were added to each formulation. The color, taste, and odor acceptability of the formulations were evaluated by 30 panelists using a three-point hedonic scale (1 - I like it a lot, 2 - I like it, and 3 - I don't like it).

Thermal analysis. The Paredes-López et al. (1994) method was used to determine The flours' thermal properties and best extruded formulation $\left(\mathrm{F}_{3}\right)$. In brief, after $2 \mathrm{mg}$ of starch was weighed in an aluminum cell and $7 \mu \mathrm{L}$ of water was added to it, the cell was closed. Subsequently, the cell was placed in a differential scanning calorimeter (Q20, TA Instruments, New Castle, NJ, USA) and was heated in the temperature range of $30-120^{\circ} \mathrm{C}$ (heating rate of $10^{\circ} \mathrm{C} / \mathrm{min}$ ). The data and graphs were obtained using the calorimeter software. 
Pasting. The flours' pasting propeand best extruded formulation $\left(\mathrm{F}_{3}\right)$ were analyzed using a rheometer (Ar-1500ex, TA Instruments, New Castle, NJ, USA) equipped with a starch cell. Suspension of the flours and best extruded formulation $\left(\mathrm{F}_{3}\right)$ with concentrations of $12 \%$ $(\mathrm{w} / \mathrm{w})$ were prepared using the method of PérezGallardo et al. (2012). The prepared suspensions were stirred at $500 \mathrm{~s}^{-1}$. Next, the suspensions were warmed and maintained at $40^{\circ} \mathrm{C}$ for $600 \mathrm{~s}$ followed by heating to $95^{\circ} \mathrm{C}$ (heating rate of $7.5^{\circ} \mathrm{C} / \mathrm{min}$ ). Subsequently, the suspensions were maintained at $95^{\circ} \mathrm{C}$ for $600 \mathrm{~s}$ followed by cooling to $50^{\circ} \mathrm{C}$ (cooling rate of $7.5^{\circ} \mathrm{C} / \mathrm{min}$ ). Lastly, the suspensions were maintained at $50^{\circ} \mathrm{C}$ for $120 \mathrm{~s}$.

Statistical analysis. A completely randomized design with five repetitions was used to evaluate The extruded formulations' effect on their chemical composition parameters. Analysis of variance was performed to detect the differences between the formulations' average chemical composition parameters ( $\mathrm{p} \leq 0.05$ ). The least significant difference test was used to compare the chemical composition parameters of the grains and formulations. The acceptability of the extruded formulations was analyzed using the Friedman test, and statistical analysis of the data was performed using the SPSS 18.0 software.

\section{RESULTS Y DISCUSSION}

Chemical composition of raw materials. Table 1 summarize the chemical compositions of fava beans, corn, and quinoa. The protein content of fava beans (32.46\%) was higher than those of corn and quinoa and higher than that reported by Hernández-Bolívar et al. (2015), confirming that fava beans are an important source of protein (Kotue et al., 2018). Quinoa presented a high content of carbohydrates (74.26\%), it was higher than those of fava beans and corn; this value was slightly higher than those reported by CerónFernandez et al. (2016) (70.30\%) and Bergesse et al. (2015) (68 - 74\%).

The fat content of corn (5.98\%) was higher than fava beans and quinoa. This value was lower than that reported by Miranda et al. (2015) (6.58\%) but was in the range reported by $\mathrm{Ai}$ and Jane (2016) (3 - 6\%). The difference was attributed to the difference in the size of the corn germs (Ai and Jane, 2016). The ash contents of quinoa (5.49\%) and corn (4.96\%) were higher than fava beans. The ash content of quinoa was higher than reported by Arzapalo et al. (2015) for white quinoa (4.40\%) but was in the range reported by Bergesse et al. (2015) (2.22 - 9.80\%).

Table 1. Energy content and chemical composition of raw materials.

\begin{tabular}{lccc}
\hline Parameter & Fava beans & Corn & Quinoa \\
\hline Energy (kcal/100 g) & $369.49 \pm 0.94^{\mathrm{a}}$ & $369.98 \pm 0.23^{\mathrm{a}}$ & $355.06 \pm 0.42^{\mathrm{b}}$ \\
Humidity (\%) & $7.73 \pm 0.47^{\mathrm{b}}$ & $10.02 \pm 0.31^{\mathrm{a}}$ & $8.92 \pm 0.53^{\mathrm{c}}$ \\
Protein (\%) & $32.46 \pm 1.12^{\mathrm{b}}$ & $9.76 \pm 0.93^{\mathrm{a}}$ & $8.79 \pm 1.32^{\mathrm{c}}$ \\
Fat (\%) & $2.13 \pm 0.65^{\mathrm{b}}$ & $5.98 \pm 0.24^{\mathrm{a}}$ & $2.54 \pm 0.33^{\mathrm{c}}$ \\
Carbohydrates (\%) & $55.12 \pm 2.36^{\mathrm{b}}$ & $69.28 \pm 2.04^{\mathrm{a}}$ & $74.26 \pm 1.23^{\mathrm{c}}$ \\
Ash (\%) & $2.56 \pm 0.65^{\mathrm{b}}$ & $4.96 \pm 0.37 \underline{\underline{a}}$ & $5.49 \pm 0.74^{\mathrm{a}}$ \\
\hline
\end{tabular}

Data presented as means \pm standard deviations. Different letters in the same row indicate significant differences $(\mathrm{p}<0.05)$. 
Chemical compositions of extruded formulations. The chemical compositions of the extruded formulations showed the variability for the characteristics studied (Table 2). Formulation $\mathrm{F}_{2}$ presented the highest energy content, which agrre with the energy recommendations of the FAO/WHO (2016) of $60-70 \mathrm{kcal} / 100 \mathrm{~mL}$. However, no significant differences were observed in the formulations' energy contents. The protein content of formulation $\mathrm{F}_{2}$ was higher than formulations $\mathrm{F}_{1}$ and $\mathrm{F}_{3^{\prime}}$ and was attributed to its fava bean content being the highest of all formulations. Cereals, legumes, and grains are vegetal protein sources. Moreover, extrusion was reported to increase the protein content of legumecontaining formulations by 1-1.5\% (Patil et al., 2016).

The formulation of F1's carbohydrate content was the highest (62.69\%) of all analyzed formulations. The water content of the formulations was low (Table 2), guarantying the stability of extruded products during storage (Tovar-Hernández et al., 2017). The fat contents of the extruded formulations showed no significant differences. This behavior agreed with CerónFernandez et al. (2016). However, extrusion was reported to increase legume-based products' digestibility by $37-62 \%$, depending on the extrusion technique (Patil et al., 2016).

Sensory analysis of extrudates. Table 3 shows outcomes of the characteristics analyzed. The panelists reported significant differences in the taste and odor acceptability of the samples, and the sample with the highest odor and taste acceptability was formulation $\mathrm{F}_{3}$. No significant differences were observed in the color acceptability of the formulations. This was attributed to The formulations' quiona content". Jiangping (2017) mentioned that extrusion significantly affected the organoleptic characteristics of color and bouquet because of the high temperature used during the process. However, to maintain these characteristics is advisable to add colorant additives to formulations.

Table 2. Energy content, chemical composition, and digestibility of extruded formulations.

\begin{tabular}{lccc}
\hline \multirow{2}{*}{ Parameter } & $\mathbf{F}_{1}$ & $\mathbf{F}_{2}$ & $\mathbf{F}_{3}$ \\
\cline { 2 - 4 } & $366.74 \pm 3.40^{\mathrm{a}}$ & $369.88 \pm 2.80^{\mathrm{a}}$ & $368.15 \pm 3.90^{\mathrm{a}}$ \\
\hline Energy (kcal/100 g) & $18.24 \pm 0.03^{\mathrm{a}}$ & $19.17 \pm 0.04^{\mathrm{b}}$ & $18.64 \pm 0.08^{\mathrm{c}}$ \\
Proteins (\%) & $4.78 \pm 0.21^{\mathrm{a}}$ & $4.88 \pm 0.19^{\mathrm{a}}$ & $4.87 \pm 0.32^{\mathrm{a}}$ \\
Fat (\%) & $7.80 \pm 0.04^{\mathrm{a}}$ & $8.00 \pm 0.13^{\mathrm{b}}$ & $8.40 \pm 0.05^{\mathrm{c}}$ \\
Humidity (\%) & $3.15 \pm 0.01^{\mathrm{a}}$ & $3.11 \pm 0.06^{\mathrm{a}}$ & $2.99 \pm 0.01^{\mathrm{b}}$ \\
Ash (\%) & $3.34 \pm 0.01^{\mathrm{a}}$ & $2.52 \pm 0.02^{\mathrm{b}}$ & $2.66 \pm 0.03^{\mathrm{c}}$ \\
Fiber (\%) & $62.69 \pm 0.08^{\mathrm{b}}$ & $62.32 \pm 0.23^{\mathrm{a}}$ & $62.44 \pm 0.16^{\mathrm{a}}$ \\
Carbohydrates (\%) & $72.80 \pm 1.28^{\mathrm{a}}$ & $71.9 \pm 0.98^{\mathrm{a}}$ & $72.60 \pm 1.08^{\mathrm{a}}$ \\
\hline Digestibility (\%) & &
\end{tabular}

$\mathrm{F}_{1}: 38 \%$ extruded fava bean flour, $50 \%$ extruded quinoa flour, and $12 \%$ extruded corn flour; $\mathrm{F}_{2}: 36 \%$ extruded fava bean flour, $52 \%$ extruded quinoa flour, and $12 \%$ extruded corn flour; $\mathrm{F}_{3}: 30 \%$ extruded fava bean flour, $50 \%$ extruded quinoa flour, and $12 \%$ extruded corn flour.

Data presented as means \pm standard deviations. Different letter in the same row indicate significant differences $(p<0.05)$. 
Table 3. Sensory acceptability of the extruded formulations.

\begin{tabular}{cccc}
\hline Formulation & Color & Taste & Odor \\
\hline $\mathrm{F}_{1}$ & $1.90 \pm 0.71^{\mathrm{a}}$ & $2.70 \pm 0.46^{\mathrm{c}}$ & $2.43 \pm 0.57^{\mathrm{b}}$ \\
$\mathrm{F}_{2}$ & $1.93 \pm 0.69^{\mathrm{a}}$ & $2.53 \pm 0.68^{\mathrm{bc}}$ & $2.33 \pm 0.71^{\mathrm{b}}$ \\
$\mathrm{F}_{3}$ & $1.47 \pm 0.51^{\mathrm{a}}$ & $1.73 \pm 0.52^{\mathrm{a}}$ & $1.63 \pm 0.61^{\mathrm{a}}$ \\
\hline
\end{tabular}

Data presented as means \pm standard deviations. Different letters in the same column indicate significant differences $(\mathrm{p}<0.05)$.

The extruded formulation with the highest odor and taste acceptability was $\mathrm{F}_{3}$. It was attributed to the quinoa content because Cerón-Fernandez et al. (2016) reported that quinoa grains contributed to the sweetness of extruded formulations. The taste acceptability of the formulations was attributed to the extrusion process, affecting the characteristics of fava beans, quinoa, and corn; improving the texture and reducing the quinoa and fava beans' bitter taste (Patil et al., 2016). Formulation $\mathrm{F}_{3}$ presented a better sweet taste in the final product. The panelists favored formulation $\mathrm{F}_{3}$ and indicated that this sample presented a pleasant color and sweet taste; Cerón-Fernandez et al. (2016) reported similar results. The extruded formulations' quiona content did not affect the color or appearance of the formulations.

Thermal properties. The thermograms of the non-extruded fava beans, quinoa, corn flours and extruded formulation with the highest acceptability $\left(\mathrm{F}_{3}\right)$ are in Figure 1. The gelatinization temperatures of the non-extruded flours were higher than the extruded formulation. These differences were attributed to the non-extruded flours containing native starch (Velásquez-Barreto et al., 2019). This did not occur for the extruded formulation because the starch had already been gelatinized during extrusion. Ye et al. (2018) mentioned that, starch granules gelatinized and proteins were denatured during extrusion, improving their digestibility, texture, and organoleptic properties.
Moreover, the drinks prepared for sensory analysis presented a good dispersion due to starch gelatinization. Conversely, the extruded products presented high or complete gelatinization of native starch, indicating that extrusion was efficient, due to the absence of a gelatinization temperature from the thermogram of formulation $\mathrm{F}_{3}$ (Figure 1).

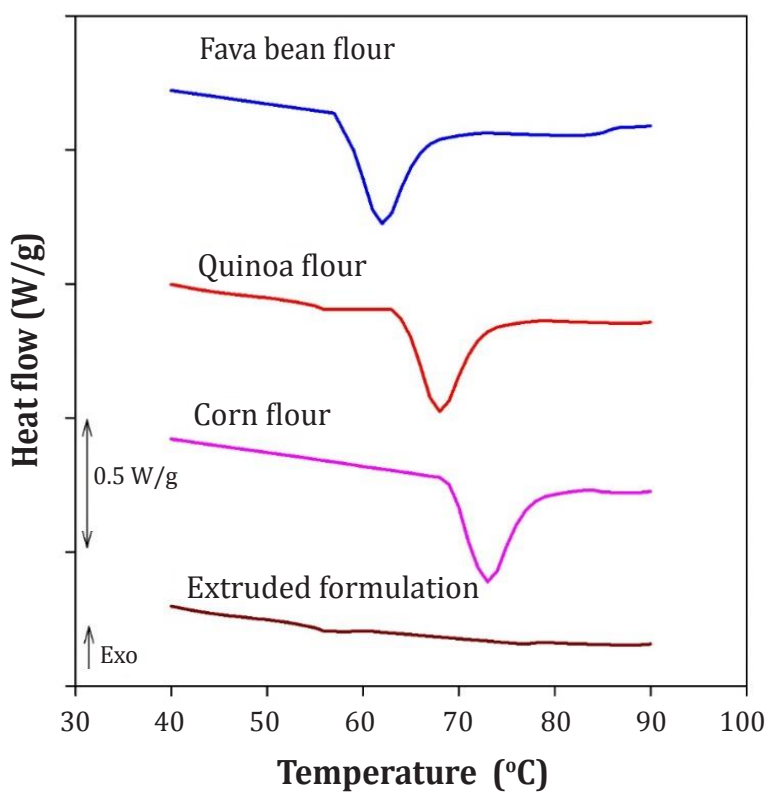

Figure 1. Thermograms of non-extruded fava bean, quinoa, and corn flours, and extruded formulation $\left(\mathrm{F}_{3}\right)$.

Pasting. Pasta obtained from non-extruded fava beans, quinoa, and corn presented similar comportments (Figure 2), and differed from the extruded formulation with the highest acceptability $\left(\mathrm{F}_{3}\right)$. This behavior was attributed to the native starch swelling upon heating non- 
extruded flours owing to heating and mechanical agitation (Velásquez-Barreto et al., 2019). But it was not observed for the $\mathrm{F}_{3}$ formulation because the starch had already been gelatinized and lost its integrity. These results were consistent with the thermograms. Quinoa flour presented the highest peak viscosity followed by fava bean and corn flours. The gelatinization temperatures of the nonextruded corn, quinoa, and fava bean flours were $72.1,64.5$ and $68.7^{\circ} \mathrm{C}$, respectively. These results were similar to those reported by BustillosRodríguez et al. (2018), ranging between 70.6 and $72.2^{\circ} \mathrm{C}$. Moreover, Arzapalo et al. (2015) reported that the gelatinization temperature of quinoa starch was $66^{\circ} \mathrm{C}$, and Wani et al. (2016) indicated that fava beans' starch gelatinization temperature ranged between 66.6 and $70.59^{\circ} \mathrm{C}$. Formulation $\mathrm{F}_{3}$ did not present a pasting temperature or peak viscosity, indicating that the native starch in this formulation was highly or completely gelatinized and confirmed that extrusion was efficient. These results were in agreement with the thermal properties of the analyzed flour samples.

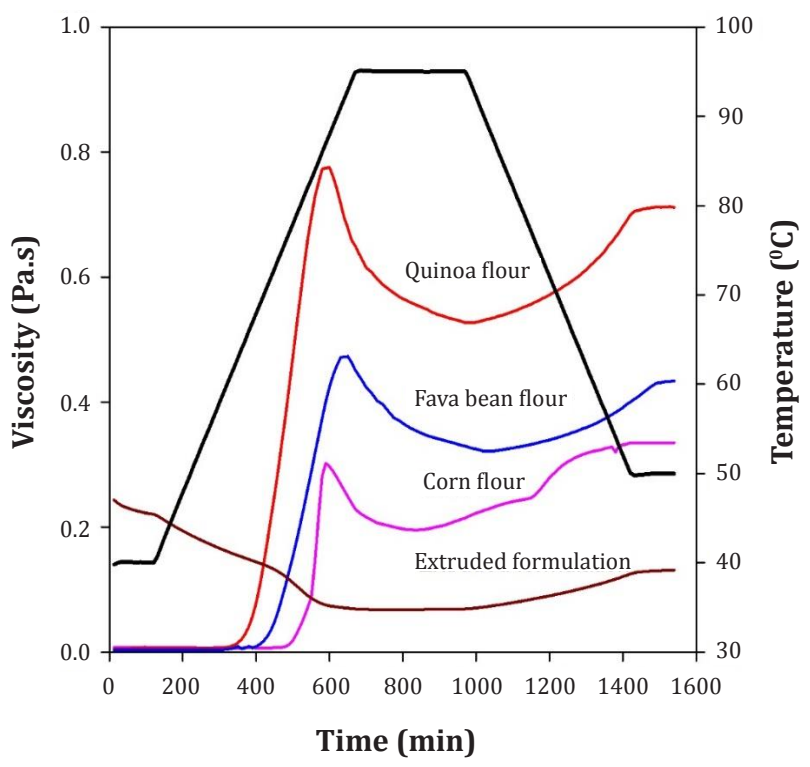

Figure 2. Behavior of non-extruded fava bean, quinoa, and corn flours and extruded formulation $\left(\mathrm{F}_{3}\right)$

\section{CONCLUSIONS}

The chemical composition and energy of fava beans, corn, and quinoa in this study agreed with the data reported in the literature. Extruded formulations of corn, fava beans, and quinoa presented the following chemical compositions: protein (18.24 - 19.17\%), fat (4.78 - 4.88\%), humidity (7.8 - 8.4\%), ash (2.99 $3.15 \%)$, fiber (2.52 - 3.34\%), carbohydrates (62.32 $-62,69 \%)$ and digestibility (71.9 - $72.8 \%$ ).

The extruded formulation with the highest acceptability consisted of fava bean (30\%), quinoa (58\%) and corn (12\%) flours; the odor, taste, and, color parameters of this formulation were $1.63,1.73$, and 1.47, respectively. The extruded formulation's thermal and pasting properties with the highest acceptability indicated that the entire amount of native starch present in the flours was gelatinized during extrusion.

This extruded formulation could be used as instant breakfast food for children and adults owing to its chemical composition and acceptability. Future studies should focus on the in vivo digestibility of these formulations and determining their amino acid balance to obtaining optimal formulations of extruded corn, fava bean, and quinoa flours.

Acknowledgements. The authors would like to thank the National University of Huancavelica for financing a part of this study.

Conflict of interest: The authors declare that there is no conflict of interest.

\section{BIBLIOGRAPHIC REFERENCES}

Ai, Y.; Jane, J. (2016), Macronutrients in Corn and Human Nutrition. Revisiones integrales en ciencia y seguridad alimentaria. 15: 581-598. doi: https:// doi.org/10.1080/10408398.2013.779568 
Alama, M.; Kaurb, J.; Khairab, H.; Guptab, K. (2015). Extrusion and Extruded Products: Changes in Quality Attributes as Affected by Extrusion Process Parameters: A Review. Critical Reviews in Food Science and Nutrition. 56(3): 445-75. doi: https:// doi.org/10.1080/10408398.2013.779568

Arzapalo, D.; Huamán, K.; Quispe, M.; Espinoza, C. (2015). Extracción y caracterización del almidón de tres variedades de quinua (Chenopodium quinoa Willd) negra collana, pasankalla roja y blanca Junín. Rev. Soc. Quím. Perú. 81 (1): 44-54.

Bergesse, A.; Boiocchi, P.; Calandri, E.; Cervilla, N.; Gianna, V.; Guzmán, C.; Miranda, V.; Patricia, P.; Montoya, P.; Mufari, J. (2015). Aprovechamiento integral del grano de quinua: Aspectos Tecnológicos, Fisicoquímicos, Nutricionales y Sensoriales. $1^{\circ} \mathrm{ed}$. Córdoba: Edgardo Luis Calandri. 262p.

Bustillos-Rodríguez, J.; Tirado-Gallegos, J.; OrdóñezGarcía, M.;Zamudio-Flores, P.; Ornelas-Paz,J.; AcostaMuñiz, C.; Gallegos-Morales, G.; Páramo-Calderón, D.; Rios-Velasco, C. (2018). Physicochemical, thermal and rheological properties of three native corn starches. Food Science and Technolpgy. 39(1): 149-157. doi: https://doi.org/10.1590/fst.28117

Cerón-Fernandez, C.; Guerra-Morcillo, L.; LegardaQuintero, J.; Enríquez-Collazos, M.; PismagPortilla, Y. (2016). Efecto de la extrusión sobre las características físico-químicas de harina de quinua (Chenopodium quinoa Willd). Biotecnología en el Sector Agropecuario y Agroindustrial. 14 (2): 92-99. doi: http://dx.doi.org/10.18684/BSAA(14)92-99

Coda, R.; Melama, L.; Rizzello, C.; Curiel, J.; Sibakov, J.; Holopainen, U.; Pulkkinen, M.; Sozer, N. (2015). Effect of air classification and fermentation by Lactobacillus plantarum VTT E-133328 on faba bean (Vicia faba L.) flour nutritional properties. International Journal of Food Microbiology. 193: 34-42. doi: https://doi.org/10.1016/j. ijfoodmicro.2014.10.012

Delgado-Andrade, C.; Olías, R.; Jiménez-López, J.; Clemente A. (2016). Aspectos de las legumbres nutricionales y beneficiosos para la salud humana. Arbor. 192(779): a313. doi: http://dx.doi. org/10.3989/arbor.2016.779n3003
Estévez, V.; Araya, M. (2016). La dieta sin gluten y los alimentos libres de gluten. Chile de Nutrición. 43 (4): 420-433. doi: http://dx.doi.org/10.4067/S071775182016000400014

Estrada, Y.; Martínez, A.; Rafael, C.; Armando, F. (2015). Characterization of Extruded Blends of Corn and Beans (Phaseolus Vulgaris) Cultivars: Peruano and Black-Querétaro under Different Extrusion Conditions. International Journal of Food Properties, 18(2): 638-2651. doi: https://doi.org/10.1080/10 942912.2014 .999862

Etemadi, F.; Hashemi, M.; Autio, W.R.; Mangan, F.X.; Zandvakili, 0. (2018). Yield and Accumulation Trend of Biomass and L-DOPA in Different Parts of Eight Faba Bean Cultivars. Crop Sci. 58(1): 2020-2028. doi: https://doi.org/10.2135/cropsci2018.03.0172

Filho, A.; Pirozi, M.; Borges J.; Pinheiro, H.; Chaves, J.; Coimbra, J. (2017). Quinoa: nutritional, functional and antinutritional aspects. Crit Rev Food Sci Nutr. 57(8): 1618-1630. doi: https://doi.org/10.1080/10 408398.2014.1001811

FAO - Food and Agriculture Organization / WHO World Health Organization. (2016). Comisión del Codex Alimentarius: Revisión de la norma para preparados complementarios (codex stan 1561987). Recovered from https://cutt.ly/ihiNbGu

Hernández-Bolívar, G.; Matute-Sapuysky, I.; MorenoHernández, D.; Araujo-González, M.; RamírezAlfonzo, L.; Linares-Padrón, H.; Mercedes-Arveláez, Y.; Loaiza-González, J.; Monsalve, J.; Judith, M. (2015). Valor nutricional de la harina de haba (Vicia faba L.) en la alimentación de alevines de Coporo (Prochilodus mariae). Revista Científica, FCV-LUZ. 25(3): 255 - 259.

Jiangping, Y.; Xiuting, H.; Shunjing, L.; Wei, L.; Jun, C.; Chengmei, L.; Zhiru, Z. (2017). Properties of starch after extrusion: A review. Starch-Stärke. 70(1112): 1700110. doi: https://doi.org/10.1002/ star.201700110

Kotue, T.C.; Marlyne, J.M.; Wirba, L.Y. (2018). Nutritional properties and nutrients chemical analysis of common beans seed. MOJ Biol Med. 3(3):41-47. doi: 10.15406/mojbm.2018.03.00074 
Mendoza-Jiménez, Y.; Eusebio-Moreno, J.; ÁlvarezGarcía, R.; Abreu-Corona, A.; Vergas-Hernández, G.; Téllez-Jurado, A.; Tovar-Jiménez, X. (2018). Actividad antioxidante de los hidrolizados proteicos del frijol común (Phaseolus vulgaris) cv negro primavera-28 y flor de durazno. Rev. Ciencias Biológicas y de la Salud. 20(2): 25-30.

Miranda, S.; Esquivel, J.; Ruiz J.; Rivers, E. (2015). Análisis proximal de granos de arroz, frijol, maíz y café comercializados en el mercado Roberto Huembes de Managua. Rev. Universidad y Ciencia. 8(13): 41-46.

Paredes-López, 0; Bello-Pérez, L., López, G. (1994). Amylopectin-structural, gelatinization and retrogradation studies. Rev. Food Chemistry. 50: 411-417.

Patil, S.; Brennan, M.; Mason, S.; Brennan, C. (2016). The Effects of Fortification of Legumes and Extrusion on the Protein Digestibility of Wheat Based Snack. Foods. 5. (26):1-8. doi: https://doi.org/10.3390/ foods 5020026

Pérez-Gallardo, A.; Bello-Pérez, L; García-Almendárez, B.; Montejano-Gaitán, G.; Barbosa-Cánovas, G.; Regalado, C. (2012). Effect of structural characteristics of modified waxy corn starches on rheological properties, film-forming solutions, and on water vapor permeability, solubility, and opacity of films. Starch/Stärke. 64: 27-36. doi: https://doi. org/10.1002/star.201100042

Peruvian Technical Standards. (2008). Análisis sensorial. Directrices para la utilización de escalas de respuestas cuantitativas (ISO 4121).

Sathya, D.; Devi, V. (2018). Nutritional and Biological properties of Vicia faba L.: A perspective review. Rev. International Food Research Journal. 25(4): 1332-1340.

Tovar-Hernández, C.; Perafán-Gil, E.; Enríquez-Collazos, M.; Pismag-Portilla, Y.; Ceron- Fernandez, L. (2017). Evaluación del efecto del proceso de extrusión en harina de quinua (Chenopodium quinoa Willd) normal y germinada. Biotecnología en el Sector Agropecuario y Agroindustrial. 15(2): 30-38. doi: http://dx.doi.org/10.18684/BSAA(15)30-38

USDA - United States Department of Agriculture. (2015). National Nutrient Database for Standard
Reference Release, 28 (Basic Reports). Recovered from https://cutt.ly/Dhi1txG

Velásquez-Barreto, F; Bello-Pérez, L.; Yee-Madeira, H.; Velezmoro, C. (2019). Esterification and Characterization of Starch From Andean Tubers. Starch-Starke. 71(1-2): 1-8. doi: https://doi. org/10.1002/star.201800101

Wani, I.; Sogi, D.; Hamdani, A.; Gani, A.; Bha, N.; Shah, A. (2016). Isolation, composition, and physicochemical properties of starch from legumes: A review. Starch-Starke. 68 (9-10): 834-845. doi: https://doi. org/10.1002/star.201600007

Ye, J.; Hu, X.; Luo, S.; Liu, W.; Chen, J.; Zeng, Z.; Liu, C. (2018). Properties of starch after extrusion: A review. Starch-Starke. 70 (1700110): 1-8. doi: https://doi.org/10.1002/star.201700110. 


\title{
Low-temperature applied to rice seed storage: an efficient protection method against fungal contamination
}

\author{
Temperatura baja aplicada al almacenamiento de semillas de arroz: Eficaz método de \\ protección contra la contaminación por hongos
}

\begin{abstract}
Raimundo Wagner Souza Aguiarr; Deyvid Rocha Brito ${ }^{2}$; Vitor L. Nascimento ${ }^{3}$; Rodrigo Ribeiro Fidelis ${ }^{4}$;
Talita Pereira de Souza Ferreira5; Gil Rodrigues Santos ${ }^{6}$
\end{abstract}

\author{
ARTICLE DATA \\ 1 Professor, PhD, Universidade Federal do Tocantins, \\ Brasil,rwsa@uft.edu.br \\ 2 Research, MSc, Universidade Federal do Tocantins, \\ Brasil,dvbrito06@hotmail.com \\ 3 Research, Ph.D, Universidade Federal do Tocantins, \\ Brasil, vitorlnasc@gmail.com \\ 4 Professor, Ph.D, Universidade Federal do Tocantins, \\ Brasil,fidelisrr@uft.edu.br \\ 5 Professor, Ph.D, Universidade Federal do Tocantins, \\ Brasil, cupufer@gmail.com \\ 6 Professor, Ph.D, Universidade Federal do Tocantins, \\ Brasil, gilrsan@uft.edu.br
}

Cite: Aguiar, R.W.S.; Brito, D.R.; Nascimento, V.L.; Fidelis, R.R.; Ferreira, T.P.S.; Santos, G.R. (2020). Low-temperature applied to rice seed storage: an efficient protection method against fungal contamination. Revista de Ciencias Agrícolas. 37(2): 49-55

doi: https://doi.org/10.22267/rcia.203702.137.

Received: January 172020.

Accepted: December 102020

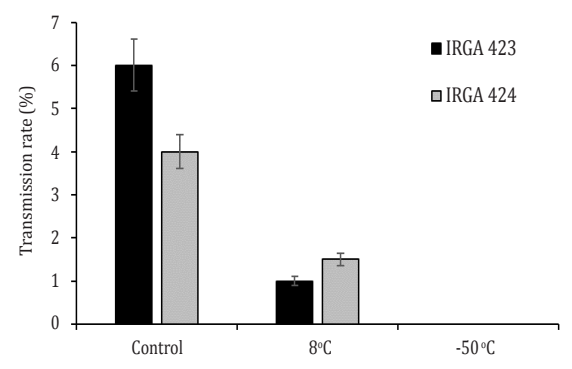

The effect of storage temperatures on fungal seed-to-seedling transmission for rice (Oryza sativa L.) IRGA 423 and 424 seeds after 90-days of storage.
ABSTRACT

Low-temperatures have long been thought to enhance seed health during storage. Here, we tested the effect of low-temperature on the mycoflora associated with rice seeds. Seeds of the IRGA 423 and 424 cultivars were stored in refrigeration $\left(8\right.$ and $\left.-50^{\circ} \mathrm{C}\right)$ or at room temperature $\left(25 \pm 10^{\circ} \mathrm{C}\right)$. Following storage $(1,45$, and 90 days) was investigated the fungi associated with the seeds. We found that low-temperature stored seeds had a lower fungal load than the seeds at room temperature for both cultivars. After 90 days of storage, there is a decrease in its incidence rate average of more than $85 \%$ in the lower temperature $\left(-50^{\circ} \mathrm{C}\right)$. All mycroflora was eliminated at 90 days except for Fusarium sp. The Trichoderma sp. was detected only in IRGA 423 seeds, whereas all other fungi were detected in the treatments in both cultivars. Only Bipolaris sp. was observed in seed-to-seedlings transmission analyses, in both cultivars, at $8^{\circ} \mathrm{C}$, and was not detected at $-50^{\circ} \mathrm{C}$. Based on our results, we recommend low-temperature storage $\left(\right.$ at $\left.-50^{\circ} \mathrm{C}\right)$ of rice seeds.

Keywords: disinfection method; mycoflora phytopathology; refrigeration; seed protection; Oryza sativa L.

\section{RESUMEN}

Las bajas temperaturas han sido pensadas para mejorar la calidad de las semillas durante el almacenamiento desde hace mucho tiempo. Nosotros hicimos un test sobre el efecto que tienen las bajas temperaturas en la micoflora asociada con las semillas de arroz. Las semillas de los cultivos IRGA 423 y 424 se almacenaron en refrigeración $\left(8 \mathrm{y}-50^{\circ} \mathrm{C}\right)$, o en temperatura ambiente $(25$ $\pm 10^{\circ} \mathrm{C}$ ). Con el seguimiento del almacenamiento ( 1,45 y 90 días), se investigó el hongo asociado con las semillas. Encontramos que, para ambos cultivos, las semillas almacenadas a bajas temperaturas presentaron más baja carga de hongos que las almacenadas en temperatura ambiente. Después de 90 días, en almacenamiento a baja temperatura hay una disminución en el promedio de su tasa de incidencia de más del $85 \%\left(-50^{\circ} \mathrm{C}\right)$. Toda la micoflora fue eliminada 
Aguiar et al.- Rice seed storage at low-temperature.

\begin{abstract}
después de 9º días exceptuando por Fusarium sp. La Trichoderma sp. Se detectó únicamente en las semillas del IRGA 423, mientras que todos los demás hongos se detectaron en los tratamientos de ambos cultivos. Sólo se observó Bipolaris sp. en los análisis de transmisión entre semillas en ambos cultivos, a $8^{\circ} \mathrm{C}$, y no se detectó a $-50^{\circ} \mathrm{C}$. Basándonos en nuestros resultados, recomendamos el almacenamiento a baja temperatura $\left(\mathrm{a}-50^{\circ} \mathrm{C}\right)$ de las semillas de arroz.
\end{abstract}

Palabras clave: método de desinfección; fitopatología de la micoflora; refrigeración; protección de semillas; Oryza sativa $L$.

\section{INTRODUCTION}

Rice (Oryza sativa L.) is one of more important commodities of the world with more than 760 Million Tons produced in 2017, highlight Asian countries' production and Brazil, one of the top 10 producers (FAOSTAT, 2019). Once this is a cereal that feeds more than half of the world's population, many efforts have been made to food security of this crop (Godfray et al., 2010). In this sense, fungal contamination is the one of main problems related to seed production and storage; therefore, the elimination or minimization of contamination by mycotoxins and fungi is crucial for reducing economic loss in agriculture (Adeyeye, 2016).

Seed storage is complicated by climatic conditions between regions and the potential reduction of quality. However, treatments as chemical disinfection, heat and/or ionizing radiation have been developed aimed to reduce the number of microorganisms infesting the surface and inner tissue of seeds (Khamsen et al., 2016). In this context, low-temperature emerges as an interesting process of storage and sterilization of seeds (Cardoso et al., 2004), yet during this time, and temperature variation, stored rice seeds may lose physiological quality (Marini et al., 2012). However, we previously demonstrated that rice seeds can be stored at low-temperature without losing physiological quality (Aguiar et al., 2012; Aguiar et al., 2015). Besides that, low-temperature technology has proven effectiveness in reducing the microbial population on the food surface not permitting the invasion by storage fungi, reduce the potential for attack by pathogenic microorganisms, and minimizing the loss of quality (Zuchi and Bevilaqua, 2012).

Once seed storage at elevated-temperature can lead to deterioration despite sterilization, and there is a clear need for studies aimed at establishing suitable storage conditions for rice seeds, here we evaluate the effect of low-temperature storage on the sanitary quality of rice seeds, testing different temperatures of storage and if occurs some seedto-seedling transmission.

\section{MATERIAL AND METHODS}

Plant material and seed treatments. Seeds used in this study, cultivars IRGA 423 and 424 (Irga ®), were obtained from the rice seed agro-industries from Formoso do Araguaia and Lagoa da Confusão, in the state of Tocantins - Brazil. Collected seeds were placed in a forced airflow dryer (BKIA, Carlos Becker ${ }^{\circledR}$ ) until reaching $11 \%$ of humidity. The cooling process of seeds was realized in two chambers with temperature control $\left(8\right.$ and $\left.-50^{\circ} \mathrm{C}\right)$ and a capacity of 20L. Seeds were then packed $(1.5 \mathrm{~kg})$ in sealed chambers with a volumetric capacity of $2 \mathrm{~L}$ and stored at $8 \pm 1^{\circ} \mathrm{C}$ or $-50 \pm 1^{\circ} \mathrm{C}$. The controls were kept in a paper bag $(2 \mathrm{~kg})$ at room temperature (uncontrolled conditions) with an average temperature of around $25 \pm 10^{\circ} \mathrm{C}$.

\section{Microbiological analysis and fungal} identification. To analyze the effect of lowtemperate storage on rice seeds' protection against fungal contaminations, the samples were transferred to sterile stomacher bags containing 50mL Butterfield's Phosphate Buffer after each 
storage time. The bags were kneaded for $3 \mathrm{~min}$ to obtain a homogenized spore solution. Serial dilutions were operated, and $0.5 \mathrm{~mL}$ of solution was spread on each plate with Dichloran Rose-Bengal Chloramphenicol medium. After 3 days of culturing at $30^{\circ} \mathrm{C}$, the colonies were labelled. Two replicate in triplicate were performed for each sample, and the mean of six replicates \pm standard deviation was reported. The initial spore population of untreated samples was $1.3 \times 10^{7} \mathrm{CFU} \mathrm{g}^{-1}$. The fungal identity was confirmed based on colony morphology and spore characteristics, according to Kimati et al. (1997). Single spore cultures of these fungus strains were maintained on Potato Dextrose Agar medium at $27^{\circ} \mathrm{C}$. Inoculum was prepared by using the conidia of two-week-old cultures of the fungi. The conidia were removed from the medium's surface_by flooding with sterile distilled water and gentle rubbing with a sterilized glass rod. The suspensions were filtered through cotton wool removing mycelial fragments and adjusted to $10^{5}$ conidia $\mathrm{mL}^{-1}$. Following this, all conidial and spore suspensions were used for inoculation in PDA culture medium. The results were expressed in the percentage of incidence of each fungus.

\section{Pathogen transmission via seed-to-seedling} test. Seed-to-seedling pathogen transmission analyses were done as described by Lucca Filho (1991), using seeds stored for 90 days. One-hundred seeds of each treatment were sown in sterilized recipients containing 10\% bacteriological agar substrate and sterile water. Inoculum was prepared by using the conidia of twoweek-old cultures of the fungi. The conidia were dislodged from the medium's surface_by flooding with sterile distilled water and gentle rubbing with a sterile glass rod. The suspensions were filtered through cotton wool removing mycelial fragments and adjusted to $10^{5}$ conidia $\mathrm{mL}^{-1}$. The percentage of transmission was calculated according to the seed-associated mycoflora's transport rate and the corresponding number of seedlings that developed disease symptoms.

Experimental design and statistical analysis. The experiment was conducted in a factorial arrangement of $3 \times 3 \times 2$, with three storage periods (1, 45 and 90 days), three temperatures $\left(25 \pm 10^{\circ} \mathrm{C}, 8^{\circ} \mathrm{C}\right.$, and $\left.-50^{\circ} \mathrm{C}\right)$, and two cultivars (IRGA 423 and 424). A completely randomized experimental design was used, with four replications (100 seeds per treatment, 25 seeds per plate), following the description in the Rules for Seed Testing - RAS (Ministério da Agricultura, Pecuária e Abastecimento, 2009). The data, obtained in percentage, were submitted to analysis of variance (ANOVA) and Tukey's test ( $p$ $\leq 0.05$ ), using statistical software R (R Core Team, 2019).

\section{RESULTS AND DISCUSSION}

In total, we found 14 fungal genera in the IRGA 423 seeds and 13 in the IRGA 424 seeds (Figure 1). The incidence of pathogenic fungi was higher for control seeds than_those stored at low temperatures (Figure 1 and Table 1). It was verified that at $-50^{\circ} \mathrm{C}, 45$ days of storage was a protection treatment, inhibiting the fungi's development with a_reduction of more than $60 \%$ of incidence average, and 90 days, the reduction was more than $85 \%$ (Table 1). Low-temperature storage massively reduces fungal infection on rice seeds, and almost all fungi were eliminated, except for Fusarium sp., which only reduced its incidence rate. The Trichoderma sp. was detected only in IRGA 423 seeds, whereas all other fungi detected were found in both cultivars (Figure 1). However, during the storage, when subjected to $-50^{\circ} \mathrm{C}$, it was eliminated from the rice seed. 


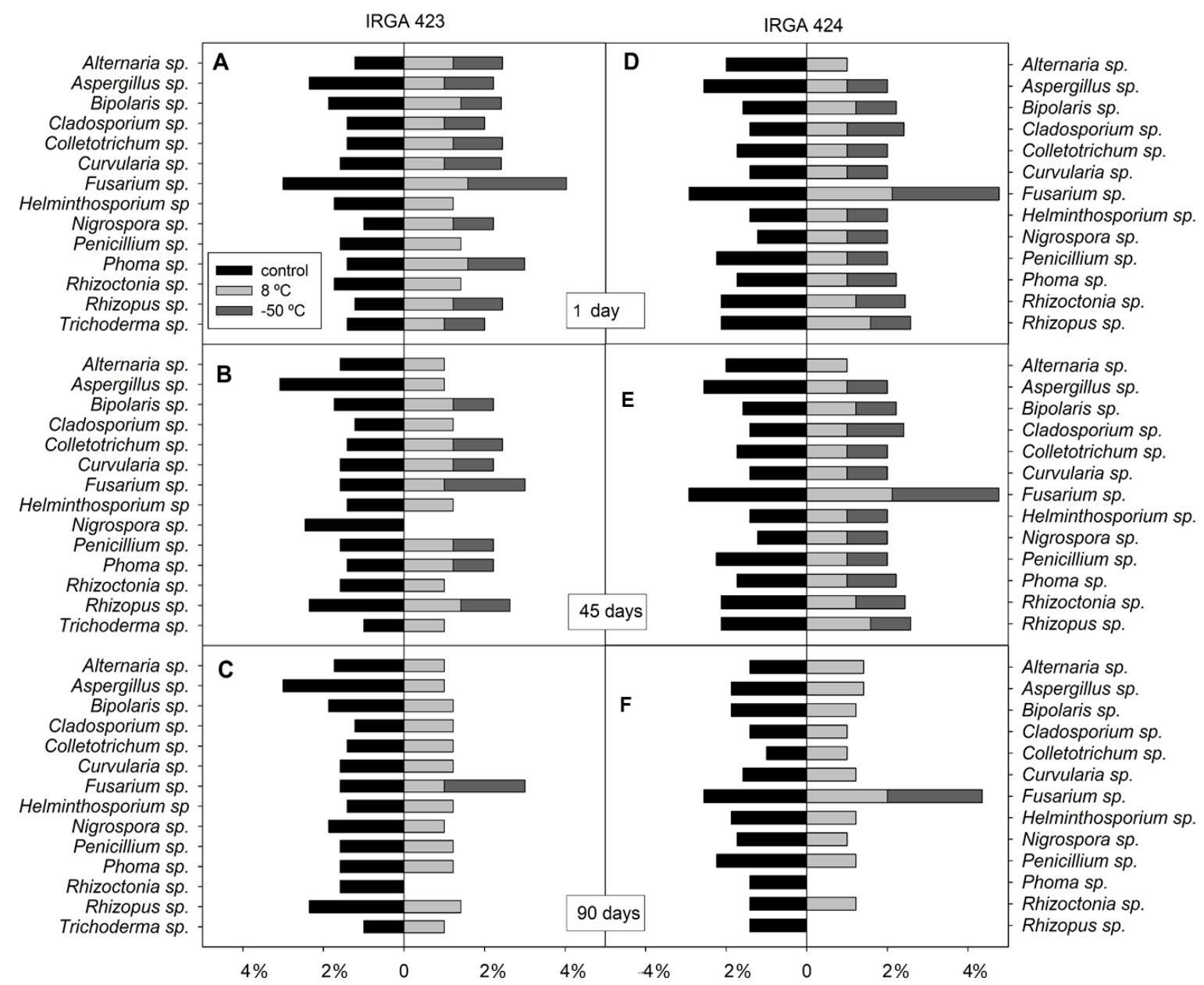

Figure 1. The microflora (percentage of infestation) of IRGA 423 (A, B, and C) and 424 (D, E, and F) rice seeds (Oryza sativa L.) after 1 (A and D), 45 (B and E), and 90 (C and F) days of storage at different temperatures.

Table 1. Average of fungi incidence rate per treatment calculated as a percentage of occurrence.

\begin{tabular}{cccccccccc}
\hline & \multicolumn{3}{c}{$\mathbf{1}$ day } & \multicolumn{4}{c}{$\mathbf{4 5}$ days } & \multicolumn{3}{c}{$\mathbf{9 0}$ days } \\
\cline { 2 - 10 } & control & $\mathbf{0 8}{ }^{\circ} \mathbf{C}$ & $\mathbf{- 5 0}{ }^{\circ} \mathbf{C}$ & control & $\mathbf{0 8}^{\circ} \mathbf{C}$ & $\mathbf{- 5 0}{ }^{\circ} \mathbf{C}$ & control & $\mathbf{0 8}{ }^{\circ} \mathbf{C}$ & $\mathbf{- 5 0}^{\circ} \mathbf{C}$ \\
\hline IRGA 423 & $1.64 \pm 0.14$ & $1.25 \pm 0.06$ & $1.01 \pm 0.18$ & $1.71 \pm 0.15$ & $1.07 \pm 0.09$ & $0.60 \pm 0.18$ & $1.70 \pm 0.14$ & $1.07 \pm 0.09$ & $0.14 \pm 0.15$ \\
IRGA 424 & $1.88 \pm 0.14$ & $1.17 \pm 0.10$ & $1.12 \pm 0.16$ & $1.69 \pm 0.11$ & $1.13 \pm 0.12$ & $0.64 \pm 0.20$ & $1.67 \pm 0.11$ & $1.07 \pm 0.15$ & $0.18 \pm 0.18$ \\
\hline
\end{tabular}

In our seed-to-seedlings transmission analyses, only Bipolaris sp. was observed. For IRGA 423, Bipolaris sp. was detected in $6 \%$ of the control seedlings but only $1 \%$ of the $8^{\circ} \mathrm{C}$ stored seedlings
(Figure 2). For IRGA 424, Bipolaris sp. was detected in $4 \%$ of the control seedlings and $1.5 \%$ of those stored at $8^{\circ} \mathrm{C}$. No pathogen transmission was detected in the $-50^{\circ} \mathrm{C}$ treatment groups (Figure 2). 


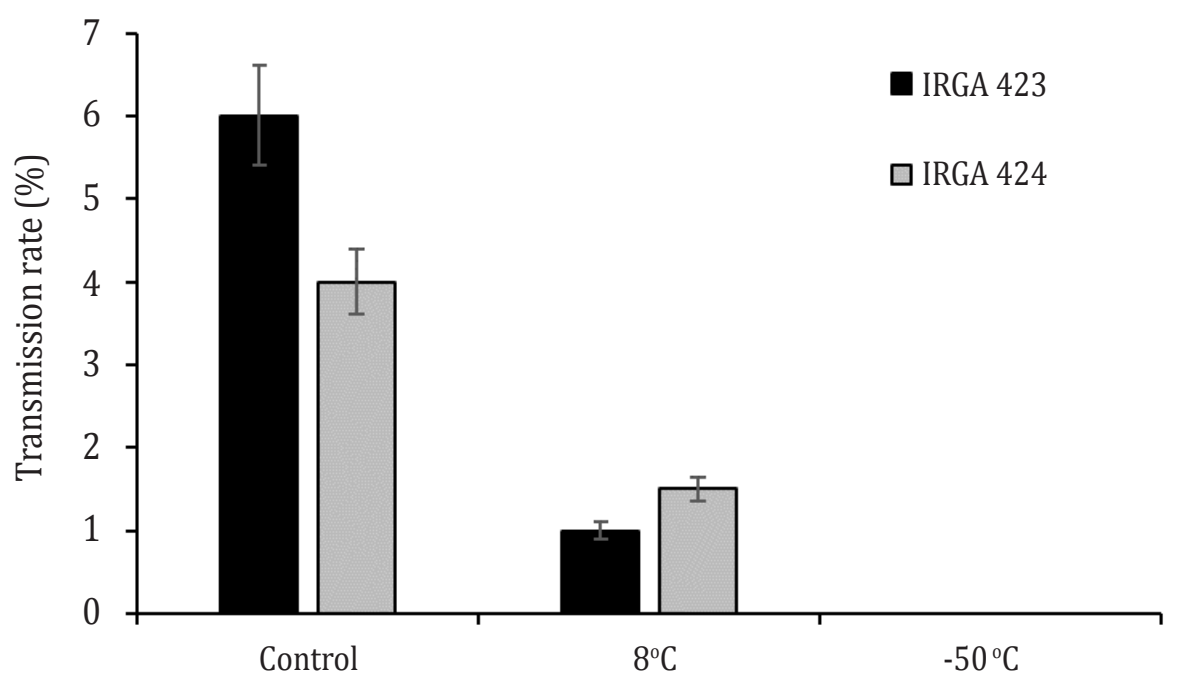

Figure 2. The effect of storage temperatures on fungal seed-to-seedling transmission for rice (Oryza sativa L.) IRGA 423 and 424 seeds after 90days of storage.

For rice seeds, temperatures above $26^{\circ} \mathrm{C}$ are considered harmful to seed quality due to gradual biochemical or physiological changes (Marini et al., 2012). Medina et al. (2009) reported poor germination and viability for triticale seeds stored under uncontrolled conditions and an increasing level of storage fungi, mainly Penicillium spp. Our findings are in line with those of Tanaka et al. (2001) that evaluated the incidence of fungi associated with corn seeds during 12 months of storage, comparing cold room $\left(14^{\circ} \mathrm{C}\right)$ storage against an uncontrolled environment. Compared to the cold chamber, , the authors observed a higher frequency of the fungi Alternaria alternata, Bipolaris maydis, Cephalosporium acremonium, Cladosporium herbarum, and Rhizoctonia solani under the uncontrolled environment; in addition, Rhizopus spp. and Trichoderma spp. Aspergillus spp. and Penicillium spp. were also more prevalent under uncontrolled conditions.

Seed-associated fungi often damage plants during their initial development, causing them to wilt or die (Malavolta et al., 2002; Maciel et al., 2012).
According to Rey et al. (2009) and Maciel et al. (2012), seeds can serve as an inoculum source for the aerial part of seedlings. Therefore, seeds are considered as means of dissemination that might introduce pathogens into pathogen-free areas or accumulate them in already infested areas through consecutive plantings of infected seeds. Improved sanitary conditions can help reducing seed-to-seedlings pathogen transmission (Maciel et al., 2012).

In the present study, although at $8^{\circ} \mathrm{C}$ storage temperature was able reducing the transmission of Bipolaris sp. to seedlings, the fungus was not eliminated. Control of temperature of storage is an important factor for conservation of seeds in tropical regions, directly affecting the biochemical and physiological processes in rice seeds and based on our data here demonstrated and previously reported (Aguiar et al., 2012), we recommend that rice seeds be stored low-temperature, preferably at $-50^{\circ} \mathrm{C}$. Obviously, any methodologies that require a large temperature change will need a great energy cost. So, this treatment could not be 
done anywhere. Another pertinent thing is that we believe that the germination rate is maintained in these conditions however further experiments are necessary.

\section{CONCLUSIONS}

Low-temperature storage massively reduces fungal association with rice seeds.

All fungi were eliminated, except for Aspergillus sp. that reported a decrease in its incidence rate.

The Trichoderma sp. was detected only in IRGA 423 seeds, whereas all other fungi detected were found in both cultivars.

In our seed-to-seedlings transmission analyses, only Bipolaris sp. was observed in both cultivars at $8^{\circ} \mathrm{C}$, while $-50^{\circ} \mathrm{C}$ was not detected.

Based on our data, we recommend that rice seeds be stored low-temperature preferably at $-50^{\circ} \mathrm{C}$.

Conflict of interest: The authors declare that there is no conflict of interest.

\section{BIBLIOGRAPHIC REFERENCES}

Adeyeye, S.A.0. (2016). Fungal mycotoxins in foods: a review. Cogent Food \& Agriculture. 2(1). doi: https:// doi.org/10.1080/23311932.2016.1213127

Aguiar, R. W. S.; Rocha D.; Ootani M.A.; Fidelis R.R.; Peluzio J.N. (2012). Efeito do dióxido de carbono, temperatura e armazenamento sobre sementes de soja e micoflora associada. Revista Ciência Agronômica (UFC. Impresso). 43:554560. doi: https://doi.org/10.1590/S180666902012000300019

Aguiar, R. W .S.; Brito, D. R.; Lopes, M. M.; Santos, G. R.; Sousa, C. M.; Silva, E. M. M.; Didonet, J. (2015). Physiological and enzymatic changes in rice seeds stored at low temperatures. African Journal of Biotechnology. 14(31): 2434-2441. doi: https://doi. org/10.5897/AJB2015.14568
Ministério da Agricultura, Pecuária e Abastecimento. (2009). Regras para análise de sementes. Brasília: Ministério da Agricultura, Pecuária e Abastecimento. Secretaria de Defesa Agropecuária. 399p.

Cardoso, P. C.; Baudet, L.; Peske, S. T.; Lucca Fillho, 0.A. (2004). Armazenamento em sistema a frio de sementes de soja tratadas com fungicida. Revista Brasileira de Sementes. 26(1): 15-23. doi: https:// doi.org/10.1590/S0101-31222004000100003

FAOSTAT - Food and Agriculture Organization of the United Nations. (2019). Statistical Yearbook. Rome, Italy: FAOSTAT.

Godfray, H. C. J.; Beddington, J. R.; Crute, I. R.; Haddad, L.; Lawrence, D.; Muir, J. F.; Pretty, J.; Robinson, S.; Thomas, S. M.; Toulmin, C. (2010). Food security: the challenge of feeding 9 billion people. Science. 327: 812-818. doi: https://doi.org/10.1126/ science.1185383

Khamsen, N.; Onwimol, D.; Teerakawanich, N.; Dechanupaprittha, S.; Kanokbannakorn, W.; Hongesombut, K.; Srisonphan, S. (2016). Rice (Oryza sativa L.) seed sterilization and germination enhancement via atmospheric hybrid nonthermal discharge plasma. ACS Applied Materials \& Interfaces. 8: 19268-19275. doi: https://doi.org/10.1021/ acsami.6b04555

Kimati, H.; Amorim, L.; Bergamin Filho, A.; Camargo, L.E.A.; Rezende, J.A.M. (1997). Manual de Fitopatologia: Doenças das Plantas Cultivadas. Vol. 2. São Paulo, Brazil: Editora Agronomica Ceres.

Lucca Filho, 0.A. (1991). Metodologia dos testes de sanidade de sementes. In: Menten, J.O.M. (Ed.). Patógenos em sementes: detecção, danos e controle químico. p. 276-298. Piracicaba: ESALQ.

Maciel, C. G.; Ferrera, T. S.; Bovolini, M. P.; Gonzatto, R.; Muniz, M.F.B.; Buriol, G.A. (2012). Transmissão de fungos via semente e patogenicidade de Pestalotiopsis sp. em mudas de Schinus terebinthifolius Raddi. Semina: Ciências Agrárias. 33(1): 2767-2774. doi: https://doi. org/10.5433/1679-0359.2012v33Supl1p2767

Malavaolta, V. M. A.; Parisi, J. J. D.; Takada, H. M.; Parisi, M. C. M. (2002). Efeito de diferentes níveis de incidência de Bipolaris oryzae em sementes de arroz sobre aspectos fisiológicos, transmissão do patógeno às plântulas e produção. Summa Phytopathologica. 28(4):337-341. 
Marini, P.; Moraes, C. L.; Marini, N.; Moraes, D. M.; Amarante, L. (2012). Alterações fisiológicas e bioquímicas em sementes de arroz submetidas ao estresse térmico. Revista Ciência Agronômica. 43(4):722-730. doi: https://doi.org/10.1590/ S1806-66902012000400014

Medina, P. F.; Tanaka, M.A.S.; Parisi, J. J. D. (2009) Sobrevivência de fungos associados ao potencial fisiológico de sementes de triticale (X. triticosecale Wittmack) durante o armazenamento. Revista Brasileira de Sementes. 31(4):17-26. doi: https:// doi.org/10.1590/S0101-31222009000400002

R Core Team. (2019). R: A language and environment for statistical computing. Recovered from https:// www.R-project.org/

Rey, M. S.; Lima, N.B.; Santos, J.; Pierobom, C. R. (2009). Transmissão semente-plântula de Colletotrichum lindemuthinum em feijão (Phaseolus vulgaris L). Arquivos do Instituto Biológico. 76(3):465-470.

Tanaka, M. A. S.; Maeda, J. A.; Plazas, I. H. A. Z. (2001). Microflora fúngica de sementes de milho em ambientes de armazenamento. Scientia Agricola. 58(3):501-508. doi: https://doi.org/10.1590/ S0103-90162001000300011

Zuchi, J.; Bevilaqua, G. A. P. (2012). Qualidade fisiológica de sementes de arroz armazenadas em diferentes embalagens e temperaturas. Recovered from https://www.embrapa.br/busca-de-publicacoes/-/ publicacao/952737/qualidade-fisiologica-desementes-de-arroz-armazenadas-em-diferentesembalagens-e-temperaturas 


\title{
Evaluation of pre-germination treatments in Carapa guianensis AUBL.
}

\author{
Evaluación de tratamientos pre-germinativos en Carapa guianensis AUBL.
}

Pedro Pablo Baccaㅜ; Jhon Jairo Zuluaga²; Jose Ivez Perez ${ }^{3}$; Diana Lucía Burbano ${ }^{4}$; Manfred Ricardo Palacio5.

\begin{abstract}
ARTICLE DATA
Researcher, M.Sc., Corporación Colombiana de Investigación Agropecuaria - AGROSAVIA. Centro de Investigación el Mira, Tumaco, Colombia, pbacca@ agrosavia.co

2 Researcher, Ph.D., Corporación Colombiana de Investigación Agropecuaria - AGROSAVIA. Centro de Investigación Nataima, Espinal, Colombia, jzuluaga@ agrosavia.co

Researcher, M.Sc., Corporación Colombiana de Investigación Agropecuaria - AGROSAVIA. Centro de Investigación el Mira, Tumaco, Colombia, jiperez@ agrosavia.co

4 Researcher, Fundación Biofuturo. Bióloga. Profesional de investigación en Biología. Pasto, Colombia, dbiologia@ gmail.com

Researcher, Agricultural Engineer, Biologist, Corporación Colombiana de Investigación Agropecuaria - AGROSAVIA. Centro de Investigación el Mira, Tumaco, Colombia, mrpalacio@agrosavia.co
\end{abstract}

Citar: Bacca, P.; Zuluaga, J.; Perez, J.; Burbano, D.; Palacio, M. (2020). Evaluation of pre-germination treatments in Carapa guianensis AUBL. Revista de Ciencias Agrícolas. 37(2): 56-66.

doi: https://doi.org/10.22267/rcia.203702.138

Received: January 252019.

Accepted: December 102020.

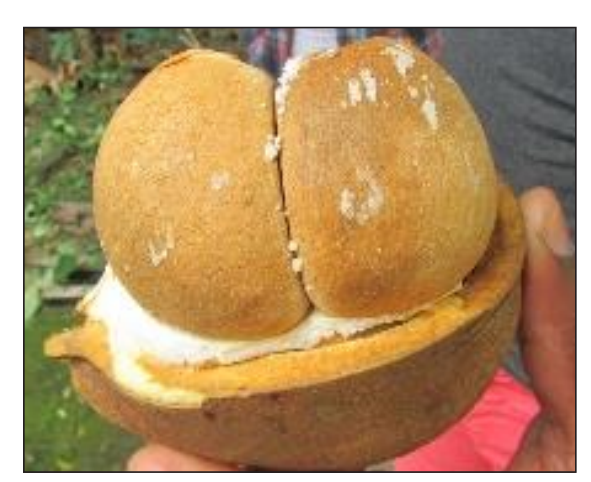

\section{ABSTRACT}

Understanding seed germination of native forest species of the Tropical wet forest is essential for ecosystem regeneration and conservation, which have been affected by the exploitation of wood and non-wood forest products. Carapa guianensis Aulb. (Meliaceae) has been exploited due to the high quality of its wood and seeds. Particularly, the latter is a source of a medicinal oil of high value to the pharmaceutical industry. The indiscriminate use of this species has reduced its population size; therefore, scientific knowledge of its sexual propagation in nurseries is vital. This research aimed to evaluate seed germination of $C$. guianensis under different pre-germination treatments and substrates at the Centro de Investigación El Mira of AGROSAVIA. Pregermination assays were conducted in a split-plot design with a random distribution of four repetitions. The cumulative germination percentage (CGP) and mean germination time $\left(t_{50}\right)$ were calculated and analyzed through an ANOVA, and Tukey's multiple comparison test using InfoStat V.2016. Significant differences for CGP among treatments $(p<0.0001)$ and interactions $(p<0.0096)$ were found. The highest germination percentage (61\%) was achieved in S1+T4; however, the $T_{50}$ did not show significant differences ( $p=0.24)$. This research demonstrates that the highest germination percentage is achieved through a scarification treatment with imbibition in sand substrate under the agroclimatic conditions of Tumaco.

Keywords: Andiroba; tropical wet forest; scarification; propagation; seeds.

\section{RESUMEN}

El estudio de la germinación de especies forestales nativas del bosque húmedo tropical es fundamental en la regeneración y conservación de este ecosistema, el cual se ha visto afectado por la explotación de los productos maderables y no maderables. En este sentido Carapa guianensis Aulb. (Meliaceae), ha sido aprovechada por su madera de alta calidad y semillas; de donde se obtiene aceite medicinal de alto valor para la industria farmacéutica. El uso indiscriminado ha disminuido su población, por cuanto generar conocimiento científico sobre 
su propagación sexual en vivero es de vital importancia. La presente investigación tuvo como objetivo evaluar la germinación de semillas de C. guianensis bajo diferentes tratamientos pre-germinativos y sustratos en el C.I El Mira de AGROSAVIA. Las pruebas pre-germinativas se realizaron mediante un diseño de parcelas divididas con cuatro repeticiones distribuidas al azar. Para el procesamiento de la información se calculó el porcentaje de germinación acumulada (PGA) y tiempo medio de germinación (t50). Los resultados se analizaron a través del ANOVA y de pruebas de comparación de Tukey mediante el programa estadístico InfoStat V.2016. Se obtuvieron diferencias significativas en PGA para los tratamientos ( $\mathrm{p}<0.0001)$ y las interacciones ( $\mathrm{p}<0.0096)$; en S1+T4, se alcanzó el mayor porcentaje de germinación (61\%). T50 no presentó diferencias significativas $(\mathrm{p}=0.24)$. La investigación demostró que, bajo las condiciones agroclimáticas del municipio de Tumaco, el tratamiento escarificación con imbibición en el sustrato arena proporcionó el mayor valor en la germinación.

Palabras clave: Andiroba; bosque húmedo tropical; escarificación; propagación; semillas.

\section{INTRODUCTION}

Tropical forests provide goods and ecosystem services that benefit the communities inhabiting these ecosystems; however, uncontrolled exploitation of wood and non-wood forest products drastically affects biodiversity and the abundance of certain native species (Palacios and Jaramillo, 2016). Indiscriminate deforestation reduces the number of seed trees; therefore, risking the future genetic base and seed propagation (Rojas, 2015). Furthermore, the scarcity of information about native forest species' propagation greatly adds to this problematic (Amaral et al., 2017).

Most tropical forest species propagate sexually; therefore, phytosanitary and genetic aspects are important to obtain quality seedlings that meet commercial expectations (Nascimento et al., 2019). However, many native species are not included in forest production plans and assessments of pregermination treatments, which is likely due to limited information in rural settings or restricted access to seeds. Furthermore, several industries, environmental authorities, and nursery growers require information about forest seeds' adequate management to achieve efficient and low-cost propagation (Nascimento et al., 2019).

Carapa guianensis Aubl. (Meliaceae), known as andiroba in Brazil (Gonçalves et al., 2018) and tangare in the Pacific coast of Nariño in
Colombia, is a promising native species of rapid growth, reaching a maximum height of $55 \mathrm{~m}$. It is distributed in South America and is native to the Amazon rainforest (Leite and Lima, 2018). This species displays important ecological characteristics, and high commercial value due to its wood and medicinal properties (Gonçalves et al., 2018; Reis et al., 2018) since the oil extracted from its seeds has pharmaceutical applications (Reis et al., 2018). Reproduction is mainly sexual (Lobo and Furtado, 2015); the fruit is a spherical capsule composed of eight seeds that animals disperse (May, 2016; Gonçalves et al., 2018; Leite and Lima, 2018). Seed harvesting is generally done by local communities who lack training regarding seed management, collection methods, or the plant population's analysis or successional structure (Guarino et al., 2014).

The exceptional characteristics of $C$. guianensis promote its high use; however, this exploitation considerably affects its population size and natural areas. Therefore, information about germination dynamics and seed morphology are important to establish seed collection and management guidelines to successfully propagate this species (Abbade and Takaki, 2014; Peixoto et al., 2019). For C. guianensis, germination behavior is variable; for instance, $24 \%$ to $90 \%$ germination can be reached in different periods ranging from days to months (Kossmann et al., 2002; Amaral et al., 2017; Hernández-Coronado et al., 2018). Therefore, 
nursery propagation alternatives for this species have led to the use of different pre-germination treatments such as mechanical scarification, sunlight exposure, and seed imbibition in sand and soil substrates (Torres et al., 2017). These methods provide adequate conditions to accelerate and increase germination of the embryo (Viveros et al., 2015).

In this context, and as part of the project entitled "Planification and management strategies for forest plantations in agroecosystems of Colombia", Corporación Colombiana de Investigación Agropecuaria (Colombian Corporation for Agricultural Research) - AGROSAVIA developed this study to evaluate to evaluate seed germination of $C$. guianensis under different pre-germination treatments and substrates in nursery conditions at the Centro de Investigación El Mira of AGROSAVIA.

\section{MATERIALS AND METHODS}

Location. This study was conducted at the Centro de Investigación el Mira of the Corporación Colombiana de Investigación Agropecuaria (AGROSAVIA), which is geographically located at $78^{\circ} 41^{\prime} 22^{\prime \prime} \mathrm{N}$ and $1^{\circ} 32^{\prime} 58^{\prime \prime} \mathrm{W}$, in Tumaco, Department of Nariño (Colombia). The study site is situated at an elevation of $16 \mathrm{~m}$ a.s.l., with a mean precipitation of $3067 \mathrm{~mm} /$ year, mean temperature of $25.5^{\circ} \mathrm{C}$, and relative humidity of $88 \%$ (Reyes et al., 2008).

Seed collection. This study used seeds from Salahonda in the municipality of Francisco Pizarro (Nariño) at $2^{\circ} 02^{\prime} 30^{\prime \prime} \mathrm{N}$ and $78^{\circ} 39^{\prime} 40^{\prime \prime} \mathrm{W}$. The seeds were collected from 10 trees according to the methodology described by Espitia-Camacho et al. (2018). The selected trees were visibly healthy and vigorous, with straight, long and accessible trunks, as Torres et al. (2017) recommended.

Physical description of the seed. A general description was made of the total seed lot based on eight samples composed of 100 units each, which were individually weighed on a Mettler Toledo tenth of a gram digital scale (Asociación Internacional de Pruebas de Semillas-ISTA, 2005; Espitia-Camacho et al. 2018). Next, the biometric properties of the seeds from each repetition were determined based on the following variables: width ( $\mathrm{mm})$, length $(\mathrm{mm})$, and thickness $(\mathrm{mm})$, measured using a Mitutoyo digital caliper. Diseased and infected seeds were discarded (HernándezCoronado et al., 2018) (Figure 1).
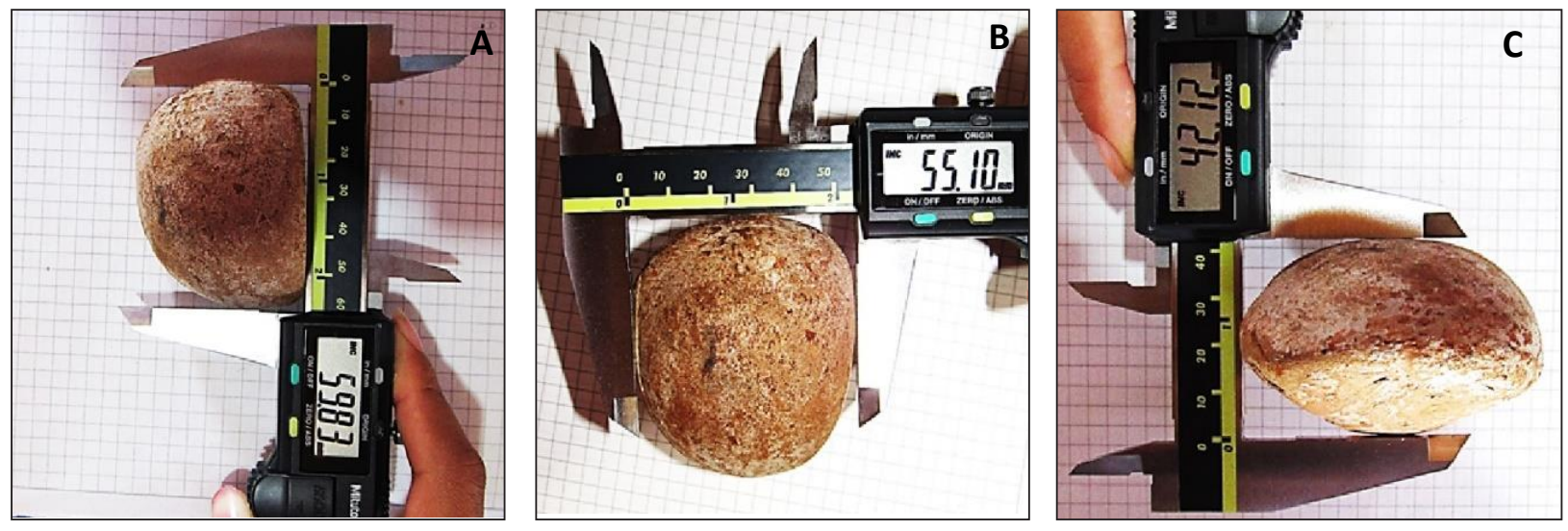

Figure 1. Seeds of $C$. guianensis. A: length (mm), B: width (mm), C: thickness (mm). 
Pre-germination treatments and substrates. Three pre-germination treatments and a control were performed (Table 1). According to the study by García et al. (2019), the pre-germination treatments were selected for tropical forest species. The substrates were selected based on Lobo and Furtado (2015), with modified proportions.

Table 1. Pre-germination treatments and substrates used for propagating C. guianensis.

\begin{tabular}{ll}
\hline Pre-germination treatments & \multicolumn{1}{c}{ Substrate } \\
\hline T1: control without treatment & S1: sand (100\%) \\
T2: sunlight exposure for 24h + imbibition for 24h & S2: sand and soil (50\%-50\%) \\
T3: mechanical scarification & S3: soil (100\%) \\
T4: mechanical scarification + imbibition for 24h & \\
\hline
\end{tabular}

The substrates were disinfected with dazomet (Theaux, 2015) at a dose of $40 \mathrm{~g} \mathrm{per}^{2}$; then, the substrate was covered with plastic for five days and left to settle for 12 more days.

Experimental design. A randomized blocks design with split-plots and four repetitions was implemented. The large plots corresponded to the substrates, namely sand (S1), sand and soil (S2), and soil (S3) (Santiago et al., 2015). Furthermore, the subplots corresponded to the seed treatments: control without treatment (T1), T2: sunlight exposure for $24 \mathrm{~h}+$ imbibition for $24 \mathrm{~h}$ (T2), mechanical scarification (T3), and T4: mechanical scarification + imbibition for 24h (T4). In total, 12 combinations were obtained, and the experimental unit was 20 seeds/pre-germination treatment for a total of 960 seeds (ISTA, 2005) (Figure 2).
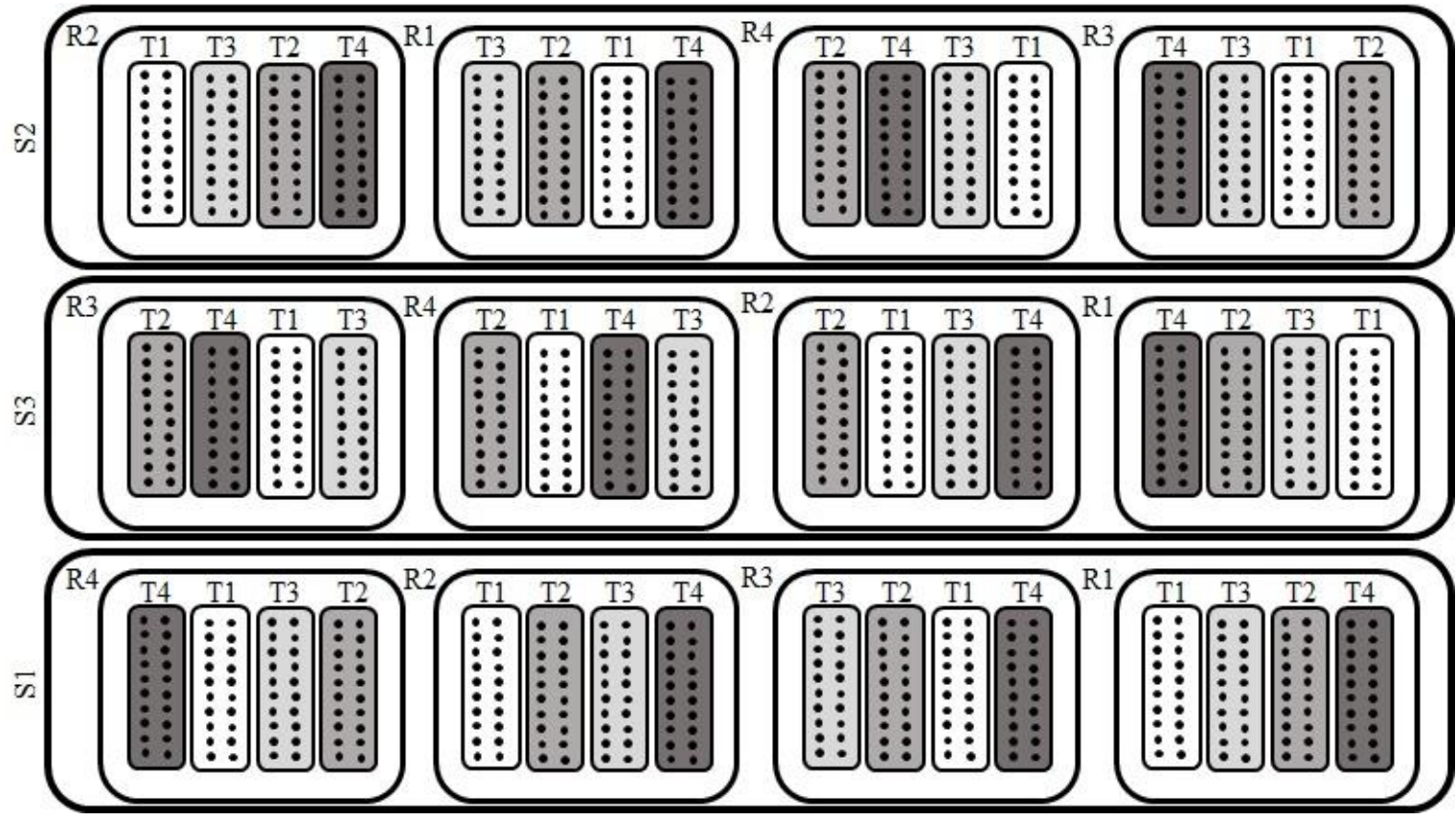

Figure 2. Split-plots design: the main plot = substrates $(\mathrm{S} 1, \mathrm{~S} 2, \mathrm{~S} 3)$, the subplots = treatments (T1, T2, T3, T4) and four repetitions (R1, R2, R3, R4). 
The effects of the pre-germination treatments and substrates were measured as the cumulative germination percentage (CGP) and mean germination time $\left(t_{50}\right)$ (Lobo and Furtado, 2015). Furthermore, the initial and final germination percentages were determined (Torres et al., 2017). After planting, the number of germinated seeds was recorded daily until day 42 (i.e., when germination remained constant). A seed was considered to have germinated when the epicotyl grew to at least $1 \mathrm{~cm}$ (Céspedes, 2018).

The CGP was calculated per experimental unit for each substrate, according to equation 1 :

$$
\mathrm{CGP}=(\mathrm{Sg} / \mathrm{Ss}) * 100 \%
$$

Where:

$\mathrm{Sg}=$ Number of germinated seeds and

Ss $=$ Number of planted seeds.

The $t_{50}$ was calculated according to equation 2 proposed by Ellis and Roberts (1978). This equation establishes the time needed to reach 50\% seed germination (Sánchez-Soto et al., 2017).

$$
\mathrm{t}_{50}=\frac{[(N / 2)-N 1) *(T 2-T 1)]}{N 2-N 1}+T 1
$$

Where:

$\mathrm{N}=$ Final $\%$ of germinated seeds.

$\mathrm{N}_{1}=\%$ of germinated seeds prior to $\mathrm{N} / 2$.

$\mathrm{N}_{2}=\%$ of germinated seeds after to $\mathrm{N} / 2$.

$\mathrm{T}_{1}=$ Number of days for $\mathrm{N} 1$.

$\mathrm{T}_{2}=$ Number of days for $\mathrm{N} 2$.

$t_{50}=$ Number of days for $\mathrm{N} / 2$.

Statistical analysis. The statistical tests were performed using InfoStat version V. 2016. The variables were tested for normality, using the Shapiro-Wilk test and Q-Q plots, as well as homoscedasticity. The treatments, substrates, and their interaction (treatments with substrates) were analyzed by a variance analysis (ANOVA), followed by Tukey's multiple comparison test. This same analysis was performed for the time of onset of germination and meantime of germination. $P$-values less than 0.05 were considered significant $(P<0.05)$ (Zar, 2010).

\section{RESULTS AND DISCUSSION}

Physical description of the seed. The seed weight of $C$. guianensis varied within a broad range (i.e., from $23.36 \mathrm{~g}$ to $49.60 \mathrm{~g}$ ), with an average of $35.7 \mathrm{~g}$. This value is higher than reported by Hernández-Coronado et al. (2018), who found an average weight of $22.1 \mathrm{~g}$ based on 100 seeds. Similarly, Kossmann et al. (2002) reported weights between 25 and $32 \mathrm{~g}$ and established that 30-50 seeds are required to obtain $1 \mathrm{~kg}$. In this study, the data indicates that approximately 28 seeds are required per kg. Peixoto et al. (2019) found different weights for $C$. guianensis, even seeds from the same fruit, and determined that this variability could be associated with the nondomestication of this species.

The other biometric parameters, such as length, width, and thickness of C. guianensis seeds, (Table 2) also showed higher variation than in Teixeira et al. (2019), who reported mean values $38.21,33.56$, and $32.95 \mathrm{~mm}$, respectively. Several researchers indicate that the agroclimatic conditions of the site can affect seed development, leading to variations in seed size, weight, and morphology (Peixoto et al., 2019). Based on the results shown in Table 2, this seed can be considered extremely large compared to other forest seeds, according to the manual of tropical and subtropical seeds of ISTA (2005). 
Table 2. Biometric data of the seed of $C$. guianensis.

\begin{tabular}{lc}
\hline \multicolumn{1}{c}{ Variable } & Mean value \pm SD \\
\hline Weight $(\mathrm{g})$ & $35.7 \pm 6.07$ \\
Length $(\mathrm{mm})$ & $59.1 \pm 3.59$ \\
Width $(\mathrm{mm})$ & $54.8 \pm 3.28$ \\
Thickness $(\mathrm{mm})$ & $43.2 \pm 4.16$ \\
\hline
\end{tabular}

SD: Standard deviation.

Evaluation of germination. The CGP did not show significant differences in response to the substrate $(P=0.9453)$; therefore, this variable did not affect germination. These results differ from reports by Severino et al. (2005) indicated that forest seeds' germination depends on the substrate since it provides different physical factors such as aeration and humidity. The pregermination treatments showed significant differences in CGP $(P<0.0001)$, as well as the interaction between substrates and pregermination treatments $(P<0.0096)$ (Table 3$)$.
Table 3. Results of the analysis of variance (ANOVA) for the split-plots.

\begin{tabular}{lcc}
\hline \multicolumn{1}{c}{ F of V } & DF & \multicolumn{1}{c}{$\boldsymbol{P}$-value } \\
\hline Model & 20 & $<0.0001^{* * *}$ \\
Substrates & 2 & $0.9453 \mathrm{~ns}$ \\
Error Factor A & 9 & 0.0018 \\
Treatments & 3 & $<0.0001^{* * *}$ \\
Interaction & 6 & $0.0096^{* *}$ \\
Error Factor B & 27 & - \\
Total & 47 & - \\
\hline
\end{tabular}

F of V; factor of the variable. DF; degrees of freedom. p: probability limits of the ANOVA. **: $P<0.01$; ${ }^{* *}: P<0.001$; ns: $P>0.05$. R squared $=0.93 . \mathrm{CV}=24.25$ Factors: factor $\mathrm{A}$ : substrates on germination $\%$ and factor B: treatments on germination $\%$.

For pre-germination treatments, Tukey's multiple comparison test indicated that treatments $\mathrm{T} 3$, and $\mathrm{T} 4$ had the highest values with similar means; therefore, these treatments do not differ and either pre-germination method is suitable (Figure 3).

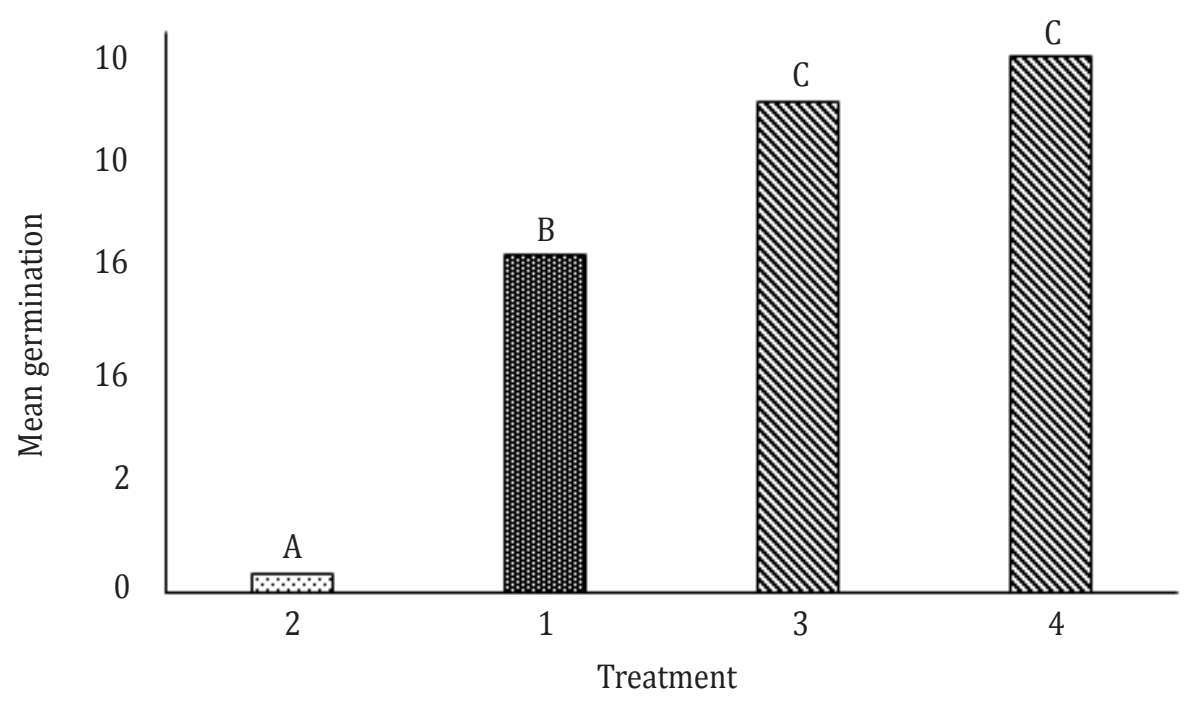

Figure 3. Cumulative germination per pre-germination treatment. Tukey's multiple comparison test. Different letters above the columns indicate a significant difference (Tukey. $P<0.05$ ). 
According to Figure 3, T2 does not promote germination; this finding differs from Lobo and Furtado (2015) reports. These authors assessed the effect of different levels of sunlight on $C$. guianensis and established that germination is significantly promoted under all light intensity levels. Bewley et al. (2013) mention that sunlight exposure can cause water deficits in seeds, affecting the velocity and final germination percentage andgermination variability. The results found here suggest that sunlight exposure likely induces photoinhibition of germination; thus, negatively affecting propagation. Several authors suggest that this type of seeds should be planted immediately after collection (Sánchez et al., 2015).

Tukey's multiple comparison test for the interaction between treatments and substrates (Figure 4) indicated five groups (A, B, BC, CD, D). Furthermore, T4 in S1 shows the highest mean germination $(\bar{x}=12.25)$, equal to $61 \%$ germination. The cumulative germination percentage (Figure 5) was congruent with this result; accordingly, T4 in S1 showed the highest germination percentage than other substrates and treatments. Overall,
C. guianensis was found to germinate gradually, which agrees with reports by Villota (2016) and Hernández-Coronado et al. (2018).

No significant differences $(P=0.32)$ were found for the initial germination percentage, as shown in Figure 5. However, the highest value was found for T4 in S2, it reached 8\% germination on day 18 of the experiment (Figure 5B). Villacorta (2010) reported the same results and determined that this species' onset of germination occurred on day 18 after planting, based on a previous imbibition treatment for 48 hours at room temperature. However, these results differ from those found by Vianna (1982), who assessed the behavior of Andiroba seeds in Tapajos National Forest (Santarém. PA). The author reported that onset of germination occurred at day 1 , without applying pre-germination treatments. Conversely, Villota (2016) reported that the onset of Carapa amorphocarpa $\mathrm{W}_{\text {., a species of the same }}$ family, occurred on day 43 in sand + soil substrate. Sanchez et al. (2019) indicated that C. guianensis develops better in very humid substrates, such as soil, storing and retaining moisture.

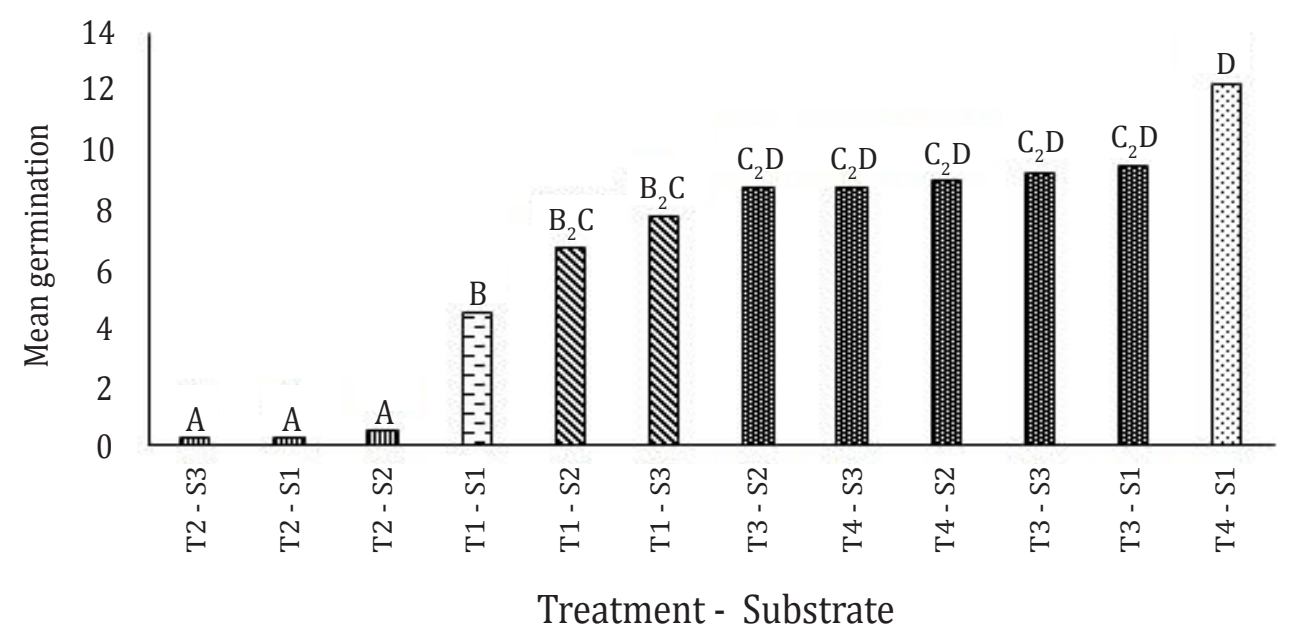

Figure 4. Cumulative germination for pre-germination treatments and substrates interaction. Tukey's multiple comparison test. Different letters above the columns indicate significant differences (Tukey. $P<0.05$ ). 

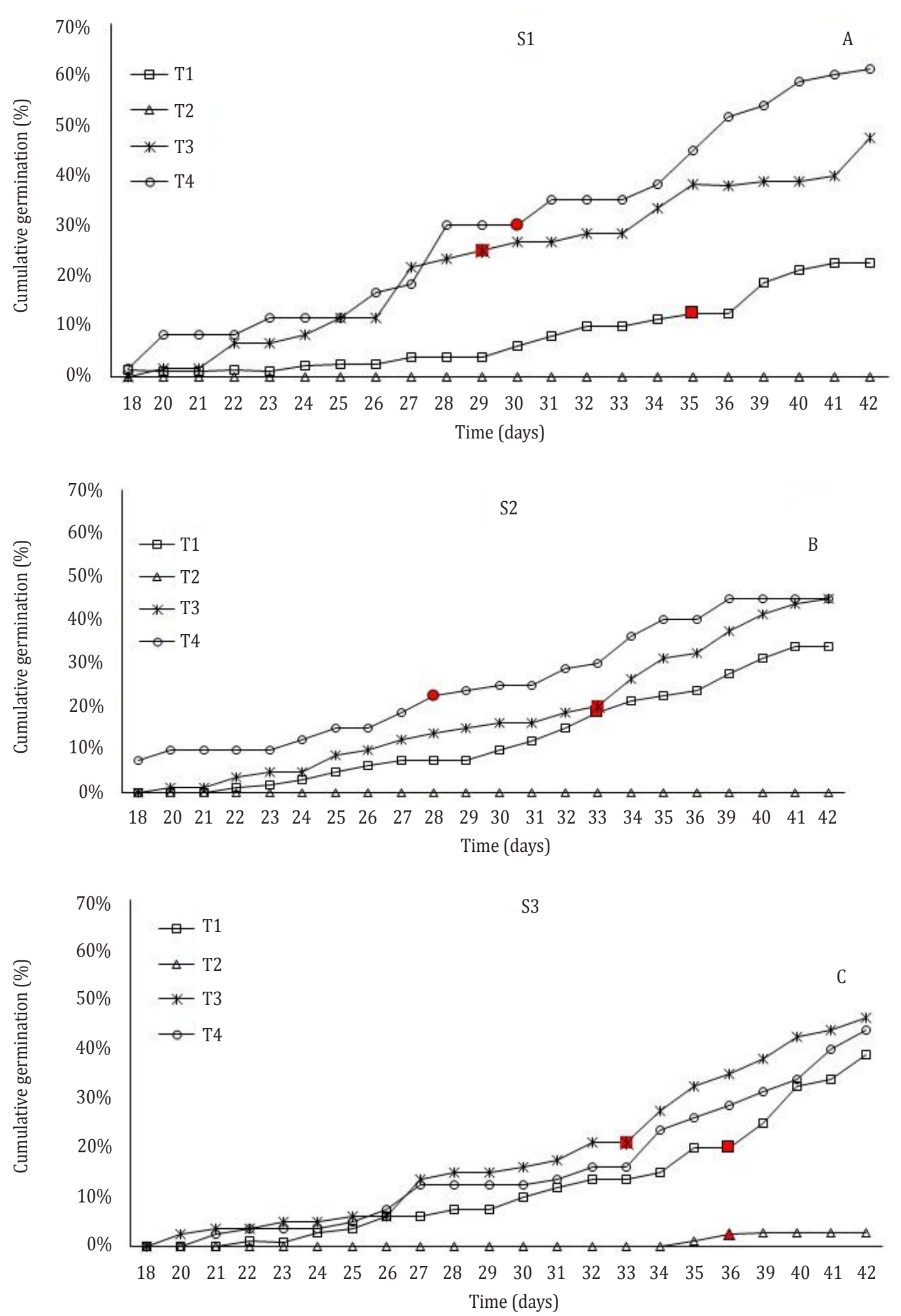

Figure 5. The Behavior of the cumulative germination percentage of $C$. guianensis. A: S1; B: S2; C: S3 under pre-germination treatments: T1; T2; T3; T4. Shapes in red: mean germination time $\left(t_{50}\right)$. 
Regarding the final germination percentage (Figure 5), T4 in S1 reached 61\% after 42 days (Figure $5 \mathrm{~A}$ ), while $\mathrm{T} 2$ showed $0 \%$ to $3 \%$ germination in the same period. These results exceed those reported by Kossmann et al. (2002). He determined that C. guianensis only reached 30\% germination in 40 dayswithout any treatment. Scarano et al. (2003) a hard wood tree from the Brazilian Amazon, has large recalcitrant seeds that can germinate and establish in both flood-free (terra-firme mention that $88 \%$ of seeds germinated after 30 days, $82 \%$ after 2 months, and $70 \%$ after 90 days after a flotation technique applied to different seed lots of $C$. guianensis.

There were no significant differences $(P=0.24)$ in $t_{50}$ for the total number of germinated seeds. The mean germination time ranged from 28 to 36 days. The lowest value was obtained for T4 in S2 $\left(t_{50}=28\right.$ days with $23 \%$ germination), indicating that less time was required to reach $50 \%$ germination than in other treatments and substrates. Meanwhile, T2 in S3 $\left(t_{50}=36\right.$ days with $\left.3 \%\right)$ showed the highest mean germination time. Nevertheless, this result is lower than Myers (2013) reported because he found a mean germination time of 65 days of $C$. guianensis. The results differ from those reported for Swietenia macrophylla King., a species of the same family (Meliaceae) since it displays a germination time ranging from 8 to 14 days (Céspedes, 2018). Therefore, seed germination and establishment requirements are species-specific and are influenced by the characteristics of the region that the species has adapted to (Sánchez et al., 2019).

\section{CONCLUSIONS}

The C. guianensis seeds' biometric characteristics from Tumaco-Nariño allow classifying the seeds as relatively large (weight: $35.7 \mathrm{~g}$, length: $59.1 \mathrm{~mm}$, width: $54.8 \mathrm{~mm}$, and thickness: $43.2 \mathrm{~mm}$ ).

A comparison of the CGP of $C$. guianensis reported in different studies, including this study, shows that germination is highly variable and likely depends on agroecological conditions.

By comparing the CGP with other studies, we determined that germination of $C$. guianensis is highly variable and it likely depends on the agroecological conditions of the site. Therefore, in ecosystems similar to the one found in TumacoNariño, the interaction of mechanical scarification + imbibition for $24 \mathrm{~h}$ in sand substrate allows cumulative germination of $61 \%$.

The mean germination time ranged from 28 to 36 days; however, it was not affected by the pregermination treatments and substrates used, indicated by non-significant differences.

\section{ACKNOWLEDGMENTS}

The authors thank the Corporación Colombiana de Investigación Agropecuaria (Colombian Corporation for Agricultural Research) (AGROSAVIA) for funding this study and the professional support team at C.I El Mira for their support in collecting the information.

Conflict of interest: The authors declare that there is no conflict of interest.

\section{BIBLIOGRAPHICAL REFERENCES}

Abbade, L.; Takaki, M. (2014). Teste de tetrazólio para avaliação da qualidade de sementes de tabebuia roseoalba (ridl.) Sandwith - Bignoniaceae, submetidas ao armazenamiento. Revista Árvore, Viçosa-MG. 38(2): 233-240.

Amaral, T.; Furtado, H.; Sousa, L.; Vilas, R.; Rodrigues, W.; Costa, M. da. (2017). Germinação de sementes e crescimento de mudas de andiroba (Carapa guianenses Aubl.) em diferentes substratos orgânicos. Brasil: XXX CBA Congreso Brasilero de Agronomia.. 
Bewley J.D.; Bradford K.J.; Hilhorst H.W.M.; Nonogaki H. (2013). Seeds: Physiology of development, germination and dormancy (3rd edition). New York: Springer.

Céspedes, K. (2018). Determinación de los patrones de tinción y efecto de la giberelina sobre la germinación de las semillas de caoba (Swietenia macrophylla) y guayacán amarillo (Handroanthus chrysanthus). Colombia: Universidad distrital Francisco José de Caldas.

Ellis, R.H.; Roberts, E. H. (1978). Towards a rational basis for testing seed quality.. In: Hebblethwaite, P.D. pp: 605-636. (ed.). Seed Production. London: Butterworth.

Espitia-Camacho, M.; Araméndiz-Tatis, H.; CardonaAyala, C. (2018). Biométricas del fruto y semillas en genetic parameters of fruit and seed biometric characteristics in Pachira aquatica Aubl. Rev. U.D.C.A. Act \& Div. Cient. 21(1): 33-42. doi: https:// doi.org/10.31910/rudca.v21.n1.2018.660

García, G.; Camilo, B.; Quintero, L.; Guzmán, D. P.; Álvarez, J. (2019). Evaluación de la germinación de Aniba perutilis Hemsl. (Comino crespo), procedente del municipio de San Carlos (Antioquia), para el establecimiento de fuentes semilleras. Encuentro Sennova Del Oriente Antioqueño. 8-16.

Gonçalves, H.; Alves, K.; Ferreira, M.; Carvalho, A.; Lameira, 0. (2018). Fenologia reprodutiva de Carapa guianensis Aubl. no horto de plantas medicinais da embrapa amazônia oriental. Recovered from https://ainfo.cnptia.embrapa.br/ digital/bitstream/item/192728/1/FENOLOGIAREPRODUTIVA.pdf

Guarino, E. D. S.; Gessner, C.; Oliveira, L. de; Lopes, F.; Raposo, A. (2014). Estrutura etária e espacial de uma população natural de Carapa guianensis Aubl. (Meliaceae) na Amazônia Sul Ocidental Age and spatial structure of Carapa guianensis Aubl. (Meliaceae) in southwestern Amazon. Scientia Forestal. 42(101): 91-99.

Hernández-Coronado, A.; Rodríguez, A.; Candre, A.; Pinto, I.; Bernilla, A. (2018). Estudio de viabilidad y conservación de semillas de cinco especies vegetales amazónicas como base para la creación de un banco de germoplasma en el municipio de Leticia, Amazonas, Colombia. Revista del Instituto de Investigaciones de la Amazonía Peruana, 27(1): 9-23. doi: https://doi.org/10.24841/fa.v27i7.435.
ISTA - International Seed Testing Association. (2005). ISTA handbook on seed sampling (2nd ed.). Bassersdorf, Switzerland: ISTA.

Kossmann, I.; Campana, J.; Barbosa, P. (2002). Sementes e plântulas de andiroba (Carapa guianensis AUBL. e Carapa procera D. C.): aspectos botânicos, ecológicos e tecnológicos. Acta. 32(4): 647-661.

Leite, A.; Lima, K. (2018). Uso de óleo de andiroba (Carapa guianensis) na produção de velas artesanais como instrumento para o ensino de Química.Ex@ tas Online. 9(2): 39-52.

Lobo, L.; Furtado, A. (2015). The effect of light quality, temperature and substrate on seed germination and epicotyl development of Carapa guianensis, a multi-use neotropical tree. Journal of Medicinal Plants Research. 9(18): 582-593. doi: https://doi. org/10.5897/jmpr2014.5736

May, T. (2016). Aspectos de sostenibilidad de productos no maderables forestales con uso curativo en el oeste de Pará, Brasil * Aspects of Sustainability of Non-timber Forest Products Used for Health in Western Pará, Brazil Aspects de la durabilité de produits forestie. Ambiente y Desarrollo. 20(38): 69-84. doi: https://doi.org/10.11144/Javeriana. ayd20-38.aspm

Myers, R. L. (2013). Germinación de semillas y supervivencia de plántulas en pantanos dominados per yolillo Raphia taedigera (Arecaceae) en las Llanuras de Tortuguero, Costa Rica. Revista de Biología Tropical. 61(1): 47-66.

Nascimento, G. O.; Souza, D. P.; Santos, A. S.; Batista, J. F.; Rathinasabapathi, B.; Gagliardi, P. R.; Gonçalves, J. F. C. (2019). Lipidomic profiles from seed oil of Carapa guianensis Aubl. and Carapa vasquezii Kenfack and implications for the control of phytopathogenic fungi. Industrial Crops and Products. 129: 67-73. doi: https://doi.org/10.1016/j.indcrop.2018.11.069

Palacios, W. A.; Jaramillo, N. (2016). Árboles amenazados del Chocó ecuatoriano. Avances en Ciencias e Ingeniería. 8(14): 51-60. doi: https://doi. org/10.18272/aci.v8i1.508

Peixoto, A.; Braga, A.; Lima, R.; Sousa, N.; Fragoso, L.; Reis, M.; Cunha, W.; Pinheiro, A.; Resende, V.; Ferreira, C. (2019). Emergency and Growth of Andiroba Seedlings (Carapa guianensis Aubl.) in Function of the Seeds. Journal of Agricultural 
Science. 11(9): 293. doi: https://doi.org/10.5539/ jas.v11n9p293

Reis, J.; Lourenço, L.; Madeira, C.; Santos, J. Dos; Nascimiento, M. Do. (2018). Caracterização histoquímica de andiroba (Carapa guianensis aubl.), para fins fitoterápicos. Recovered from https:// www.researchgate.net/publication/330907685_ CARACTERIZACAO_HISTOQUIMICA_DE_ ANDIROBA_CARAPA_GUIANENSIS_AUBL_PARA_ FINS_FITOTERAPICOS

Reyes, R.; Rodríguez, N.; Peña, E.; Bastidas, S. (2008). Crecimiento en vivero de materiales comerciales de palma aceitera (Elaeis guineensis Jacq.) en Tumaco, Colombia. Corpoica Cienc Tecnol Agropecu. 9(2):12-18.

Rojas, D. (2015). Árbol de comino (Aniba perutilis Hemsley) una planta maderable en peligro de extinción en el sur del departamento del Huila [Universidad Nacional Abierta y a Distancia UNAD]. Recovered from http://repositorio.unan.edu. ni/2986/1/5624.pdf

Sánchez-Soto, B.; Pacheco-Aispuro, E.; Lugo-García, G.; Reyes-Olivas, Á.; García-Montoya, E. (2017). Scarification methods in seeds of Guaiacum coulteri, an endangered species that inhabits the tropical deciduous forest of northern Sinaloa, Mexico. Gayana Bot. 74(2): 262-268. doi: https:/doi. org/10.4067/S0717-66432017000200262

Sánchez, A.; Montejo, L.; Gamboa, A.; Albert-Puentes, D.; Hernández, F. (2015). Germinación y dormancia de arbustos y trepadoras del bosque siempreverde de la Sierra del Rosario, Cuba. Pastos y Forraje. 38(1): 11-28.

Sanchez, J.; Pernus, M.; Torres-Arias, Y.; Barrios, D.; Dupuig, Y. (2019). Germination ecology of seeds the tropical and subtropical zones, Cuba View project Current and future potential distribution of the flora and fauna of Cuba: exploring the effects of climate change on terrestrial biota View project. Acta Botánica Cubana. 218(2): 77-108. doi: http:// orcid.org/0000-0002-7118-8608

Santiago, 0.; Vargas, J.; Aldrete, A.; López, J.; Fierros, A. (2015). Sustratos y tamaños de contenedor en el desarrollo de Hevea brasiliensis Müll. Arg. en vivero. Revista Mexicana de Ciencias Forestales. 6(31): 94-113.

Scarano, F. R.; Pereira, T. S.; Rôças, G. (2003). Seed germination during floatation and seedling growth of Carapa guianensis, a tree from flood-prone forests of the Amazon. Plant Ecology. 168(2): 291-296. doi: https://doi.org/10.1023/A:1024486715690

Severino, L. S.; Dionízio, C. G.; Lucena, A. M. A. (2005). Seedling emergence and germination of castor seed planted in different positions. Revista de Biologia e Ciências da Terra. 5(1).

Teixeira, M.; Cardoso, M.; Silva, J.; Araújo, B. De.; Sousa, T.; Piloni, M. (2019). Biometria de sementes de andiroba (Carapa guianensis e Carapa procera) de duas diferentes áreas. In: Carvalho, A. (Ed.), Ciências Agrárias: Campo Promissor em Pesquisa 2 pp. 56-61. Jardim Carvalho: Atena Editora. doi: https://doi. org/10.22533/at.ed.1601920068

Theaux, P.; Lucalioli, V.; Kiehr, M.; Marinangeli, P. (2015). Influencia de la desinfección química de un sustrato con dicloropropneo + cloropicrina o con dazomet, sobre parametro de calidad de plantines de Primula acaulis. Bahía Blanca: Congreso Argentino de Horticultura.

Torres, J.; Medina, H.; Pinilla, H.; Córdoba, E.; Martínez, M. (2017). Propagación en vivero de la especie forestal Dipteryx oleifera Benth. mediante semillas. Revista Politecnica. 13(24): 19-26.

Vianna, N. (1982). Conservação de Sementes de Andiroba (Carapa guianensis AUBL.), Brasil: EMBRAPA-CPATU-Circular técnica.

Villacorta, M. (2010). Ensayo de propagación y crecimiento inicial de Carapa guianensis en vivero, CIEFOR. Perú: Universidad nacional de la amazonia peruana.

Villota, F. (2016). Propagación de Carapa amorphocarpa $W$. empleando diferentes tratamientos, en el noroccidente del Ecuador. Ecuador: Universidad Técnica del Norte.

Viveros, H.; Hernández, J. D.; Velasco M. V.; Robles, R.; Ruiz, C.; Rentería, A. A.; Martínez M. de J.; Hernández, J.; Hernández, M. L.; (2015). Analisis de semilla, tratamientos pregerminativos de Enterolobium cyclocarpum (Jacq.) Griseb. y su crecimiento inicial. Revista Mexicana de Ciencias Forestales. 6(30): 52-65. 


\title{
Simultaneous selection indices for yield and stability in sugarcane
}

\author{
Índices de selección simultánea de rendimiento y estabilidad \\ en caña de azúcar
}

Ramon Rea ${ }^{1}$; Orlando De Sousa-Vieira ${ }^{2}$; Rosaura Briceno ${ }^{3}$; Alida Diaz J Jose George $^{5}$

\begin{abstract}
ARTICLE DATA
Researcher, Ph.D. Institute of Advanced Studies - IDEA, Caracas, Venezuela, ramonrea13@gmail.com

2 Researcher, Ph.D. National Institute of Agricultural Research - INIA, San Felipe, Venezuela, saccharum@ hotmail.com

3 Researcher, M.Sc. Fundación Azucarera para el Desarrollo, la Productividad y la Investigación - FUNDACAÑA, Chivacoa, Venezuela, rosaurab@hotmail.com

Researcher, M.Sc. National Institute of Agricultural Research - INIA, San Felipe, Venezuela, alidajos@yahoo. com

Researcher, Engineer. National Institute of Agricultural Research - INIA, San Felipe, Venezuela, jorageme@ gmail.com
\end{abstract}

Citar: Rea, R.; De Sousa-Vieira, 0.; Briceno, R; Diaz, A.; George, J. (2020). Simultaneous selection indices for yield and stability in sugarcane. Revista de Ciencias Agrícolas. 37(2): 67-77.

doi: https://doi.org/10.22267/rcia.203702.139

Received: July 122019.

Accepted: April 162020

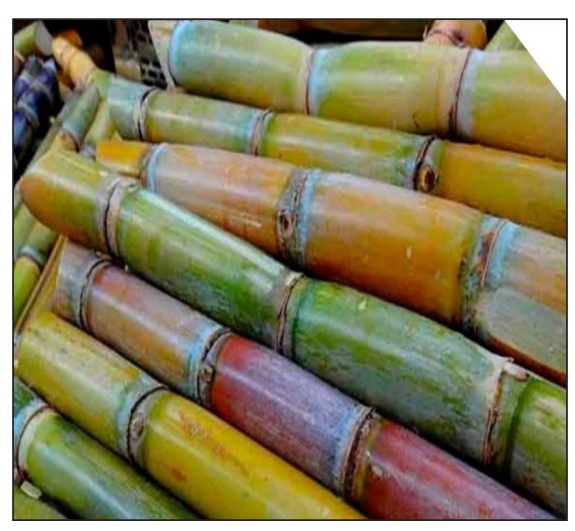

ABSTRACT

In Venezuela, sugarcane is grown in distinct environments, including soil categories and cultural practices. This research aimed to identify high-yield and stable sugarcane (Saccharum spp., hybrid) genotypes using selection indices. The experimental material consisted of sixteen genotypes and two commercial varieties as control. The genotypes were evaluated in five locations and by two harvest cycles. The yield in Ton Pol per hectare (TPH) was subjected to an analysis of variance according to the AMMI model. Methodologies of adaptability, stability, and indices that combine both stability and yield were determined. It was possible to distinguish the indices in three groups in the biplot. The superiority index (Pi), geometric adaptability index (GEI), and reliability index (Ii) were located in group 1 (G1). This group coincided in classifying genotypes CR87-339, C323-68, and V98-76 as the most stable and the best yield. The second group (G2) consisted of Kang's rank-sum (RS), Stability index (I), Sustainability index (SI), and geometric adaptability index (GDI) and located the genotypes CR87-339 and C323-68 as the most desired. The third group (G3) was constituted by the Ecovalence statistics $(W)$, Shukla's unbiased stability variance $\left(\sigma^{2} i\right)$ and the AMMI value (ASV) and classified the genotypes CP87-1762, V90-6 and CP 92-1641 as the best. The indices that best discriminated the genotypes and most associated with yield were PI, GAI and Ii.

Key words: adaptability; AMMI; biplot; hybrid; Saccharum spp.; stability index.

\section{RESUMEN}

En Venezuela, la caña de azúcar es cultivada en disímiles ambientes, incluyendo tipos de suelos y prácticas culturales. El objetivo de este trabajo fue identificar genotipos de caña de azúcar (Saccharum spp., híbrido) estables y de altos rendimientos usando índices de selección. El material experimental consistió de dieciséis genotipos experimentales y dos testigos comerciales. Los genotipos fueron evaluados en cinco localidades y dos ciclos de cosecha. Los datos de rendimiento en Tonelaje de Pol por hectárea (TPH) fueron analizados mediante el modelo AMMI. Metodologías de adaptabilidad, estabilidad e 
índices que combinan tanto estabilidad y rendimiento fueron determinadas. En el biplot se logró distinguir los índices en tres grupos. En el grupo G1 se ubicaron los índices de superioridad (Pi), adaptabilidad geométrica (GAI) y confiabilidad (Ii). Este grupo coincidió en clasificar a los genotipos CR87-339, C323-68 y V98-76 como los más estables y de mejor rendimiento. El segundo grupo (G2) estuvo conformado por los Índices de estabilidad (I), suma de rangos (RS), sostenibilidad (IS) y estabilidad genotípica (GDI) y ubicaron a los genotipos CR87-339 y C323-68 como los más promisorios. El tercer grupo (G3) fue constituido por los estadísticos Ecovalencia $\left(W\right.$ ), Varianza estabilizante de Shukla $\left(\sigma^{2}\right)$ y el valor de AMMI (ASV) y clasificaron a los genotipos CP88-1762, V90-6 y CP92-1641 como los mejores. Los índices que mejor discriminaron y estuvieron más asociados al rendimiento fueron PI, GAI e Ii.

Palabras clave: adaptabilidad; AMMI; biplot; híbrido; índices de estabilidad; Saccharum spp.

\section{INTRODUCTION}

Sugarcane (Saccharuum spp hybrid), grows in tropical and sub-tropical areas and produces approximately $70 \%$ of the world's sugar (Scortecci et al., 2012). In Venezuela, sugarcane grows up in diverse environments. One of the main goals of sugarcane breeding programs is to obtain high-yielding cultivars adapted to different agroecological regions (Rea et al., 2014). Therefore, it is essential to establish selection indices that simultaneously combine yield and stability. However, Genotype by Environment Interaction (GEI) reduces the association between genotypic and phenotypic values and affects the selection progress (Rea et al., 2014). The importance of GEI in genotype evaluations and breeding programs has been demonstrated in many crops, including sugarcane. Several statistical methods (parametric and non-parametric) have been proposed to study the GEI (Lin et al., 1986, Mohammadi and Amri, 2008). Becker and León (1988) proposed two concepts for these models: the biological or static, where the ideal genotype will be one that presents minimal variation across environments, showing a constant performance in any area of production (minimum statistical variance), and the agronomic or dynamic that represents an exiguous GEI and is associated with the pretension to obtain an increase in yield in response to environmental improvements.

The most commonly used univariate parametric methods to estimate stability are regression
(Eberhart and Russel, 1966), stability variance (Shukla, 1972) and ecovalence (Wricke, 1962). The multivariate model of the Principal Additive Effects and Multiplicative Interactions (AMMI) is based on a linear-bilinear statistical model (Crossa et al., 2004), in which the main effects of genotypes and environments are considered linear terms and are explained by conventional analysis of variance; the bilinear component (non-additive) is imputed to the GEI, and analyzed by the principal component technique. Purchase et al. (2000) developed the AMMI stability value (ASV) using the first two principal components (CP1 and CP2) of the AMMI model.

These parameters are effectively assessing adaptability, but there are cases in which the most adapted genotype does not show good yield. Due to these failures, efforts have been made to develop indices that incorporate both stability and yield in only one criterion to select new cultivars (Rea et al., 2014). Kang and Pham (1991) evaluated several methods for simultaneous selection of yield and stability and proposed the rank-sum that combines the Shukla stability variance and yield in a single value. Bajpai and Prabhakaran (2000) proposed a modified method to rank-sum termed stability index (I). The superiority index ( $\mathrm{P}$ ) of Lin and Binn (1988) integrates yield and stability and has been used in selection programs in corn (Zea mays L.), sugarcane, rice (Oryza sativa L.), and soybean (Glicyne max L.). 
The practical interest in combining high yields and stability led to the reliability index's development (Annicchiarico, 2002). Farshadfar (2008), which adds the ASV and yield in a single criterion, suggested an approach known as the genotypic selection index (GSI). The sustainability index (SI) has been used to select stable and high yield in wheat genotypes (Triticum aestivum L.) (Farshadfar et al., 2011).

The objectives of this research were: a) to identify high-yield and stable sugarcane (Saccharum spp., hybrid) genotypes and b) to evaluate the interrelation of stability index and yield.

\section{MATERIALS AND METHODS}

Experimental clones. Yield data were obtained from the sugarcane-breeding program at the National Institute for Agricultural Research (INIA), Yaracuy State-Venezuela. The evaluated material consisted of sixteen experimental genotypes: CP80-1743, CP80-1827, CP88-176, CP89-2143, CP89-2377, CP92-1213, CP92-1641, CR83-323, CR87-339, LCP85-384, V90-11, V90-14, V90-2, V90-3, V90-6 and two commercial varieties as control: C323-68 (T) and CP74-2005 (T).

Locations. The genotypes were evaluated in five locations for two years (plant and ratoon crops) in Carora, La Pastora, Turbio I (early growing season), and Turbio II (late growing season) located in Lara state, El Palmar in Aragua state, and Matilde in Yaracuy state. Table 1 shows some agroclimatic characteristics of the localities. Each genotype was planted in three-row plots of $10 \mathrm{~m}$ long and $1.5 \mathrm{~m}$ wide with three replications in a completely randomized block design. Cultural and agronomic practices prevalent for each environment were applied.
Table 1. Some agroclimatic characteristics of the evaluated localities.

\begin{tabular}{lccc}
\hline \multicolumn{1}{c}{ Locations } & rainfall $(\mathbf{m m})$ & Texture & $\mathbf{p H}$ \\
\hline Matilde & 1189 & Silt loam & 8.1 \\
Carora & 1146 & Loam & 7.3 \\
The Palmar & 1115 & Sandy loam & 6.7 \\
Rio Turbio & 700 & Clay loam & 8.0 \\
\hline
\end{tabular}

Variable evaluated. The sugarcane was burned, and the plots of each genotype were harvested by hand. A random sample of 10 stems was taken from each plot and weighed. The samples were pressed, and the juice was analyzed to determine the apparent sugar content (Pol\% cane).

The evaluated variable was cane yield expressed in TPH, which was calculated as a ratio of TCH and Pol\% cane by the formula (1) by (Pérez-Guerra et al., 2009):

$$
\mathrm{TPH}=(\mathrm{TCH} \times \mathrm{Pol} \% \text { Cane }) / 100
$$

Statistical analysis. An analysis of variance using the AMMI model was performed to access the variables. Methodologies of adaptability, stability and indices that combine both stability and yield were determined: Genotypic stability index (GSI), stability index (I), reliability index (Ii), geometric adaptability index, rank-sum (RS) and sustainability index (SI). A principal components analysis was performed using the rank of the statistics and indices. The AMMI analysis was carried out according to the model suggested by Crossa et al. (2004) equation 2.

$$
Y i j=\mu+g_{i}+\varepsilon_{j}+\sum_{k=1}^{n} \lambda_{\kappa} a_{i \kappa} \gamma_{j \kappa}+\varepsilon_{i j}
$$

Where:

Yij = Mean yield of $i$ th genotype in the $j$ th environment

$\mu=$ the general mean

$g_{i}=$ The $i$ th genotypic effect 
$\varepsilon_{j}=$ the $j$ th environment effect

$\mathrm{n}=$ the number of PCA axes retained in the model

$\lambda_{k}=$ eigen value of the PCA axis

$a_{i k}=$ the ith genotype and $j$ th environment PCA scores for the PCA axis $n$

$€ i j=$ is the residual

\section{Stability methods}

Ecovalencia. Wricke (1962) suggested using the GEI for each genotype as a measure of stability which was denominated ecovalence $(W)$.

$$
W_{i}=\sum_{i}^{e}\left(Y_{i j}-\bar{Y}_{i .}-\bar{Y}_{. j}+\bar{Y}_{. .}\right)^{2}
$$

Where: $Y_{i j}=$ Observed response of the genotype ; $\bar{Y}_{i .}=$ Average of a genotype through environments; $\bar{Y}_{. j}=$ mean yield in an environment; $\bar{Y}_{. .}=$grand mean; e = number of environments; a genotype with a low $\mathrm{W}$ value is considered high stability.

The stability variance $\left(\sigma_{i}^{2}\right)$ is based on the decomposition of the GEI into $g$ genotypes. It is equal to environmental variance within each environment $\left(\sigma_{0}^{2}\right)$ more environmental variance for each genotype, corrected for additive effects of environments, If $\sigma_{i}^{2}=\sigma_{0}^{2}$ implies that if $\sigma_{0}^{2}=0$; then the genotype will be stable.

\section{Variance of Shukla (4)}

$\hat{\sigma}_{i}^{2}=\frac{1}{(G-1)(G-2)(E-1)}\left[G(G-1) \sum_{j}\left(Y_{i j}-\bar{Y}_{i}-\bar{Y}_{j}+\bar{Y}_{i}\right)^{2}-\sum_{i} \sum_{j}\left(Y_{i j}-\bar{Y}_{i}-\bar{Y}_{j}+\bar{Y}_{i}\right)\right]$

Where: $Y_{i j}=$ Observed response of the genotype; $\bar{Y}_{i}=$ average of a genotype through environments;

$\bar{Y}_{j}=$ mean yield in an environment; $\bar{Y}=$ Grand mean; $G=$ number of genotypes; $E=$ Number of environments; low values of variance indicates that a genotype is stable.

AMMI value (ASV). The AMMI Model does not foresee a quantitative measure to estimate stability. Purchase et al., (2000) proposed the value of AMMI (AMMI stability value-ASV). The ASV is the distance from the origin in a dispersion diagram of a two-dimensional system towards the scores of CP1 vs.CP2.

$$
A S V=\sqrt{\left[\frac{[S C P 1}{\text { SSCP2 }}(\text { ScoreCPI })\right]^{2}+[\text { ScoreCP2 }]^{2}}
$$

Where: SSCP1 $=$ is the sum of squares of the first principal component (CP1); SSCP2 $=$ is the square sum of the second principal component (CP2); Score CP1 and Score CP2 are the scores of the first two principal components. Low values of ASV in the genotypes are considered widely adapted.

\section{Simultaneous selection for stability and yield}

Rank sum (RS). One of the advantages of nonparametric measures is their ease of calculating and interpreting (Rea et al., 2015). This statistic gives equal weight to the rank of yield and variance of Shukla in a single measure. The average genotype's yield was assigned the rank of 1 , and the genotype with the lowest variance of Shukla was imputed the rank of 1. Low values of the rank-sum (RS) indicate better behavior of the genotype (Kang and Pham, 1991).

RS $=$ Shukla variance rank + yield rank in TPH (6)

Genotypic stability index (GSI). This index was recommended by Farshadfar et al. (2011) and is defined as the rank sum of ASV value plus the rank sum of the genotypic mean across the environment.

$$
G S I=R A S V j+R Y ;
$$

Where: GSI is the stability index for the $\mathrm{i}^{\text {th }}$ genotype through the environment for TPH; RASVj is the rank of the $\mathrm{i}^{\text {th }}$ genotype across environment based on the ASV value (AMMI Value); $\mathrm{RY}_{i}$ is the rank of the $\mathrm{i}^{\text {th }}$ genotype based on the average in each environment. Genotypes with low GSI values were considered the best across environments. 
Stability index (I). This index was proposed by Bajpai and Prabhakaran (2000) and was computed according to the following equation:

$$
I=\left[\frac{\bar{Y}_{i .}}{\bar{Y}}+\frac{1}{\sigma_{i}^{2}}\right] /\left[\frac{1}{n} \sum_{i}\left(\frac{1}{\sigma_{i}^{2}}\right)\right]
$$

Where:

$\bar{Y}_{i .}=$ Average of $\mathrm{i}^{\text {th }}$ genotype; $\bar{Y}_{. .}=$General mean, $\hat{\sigma}_{i}^{2}=$ Shukla variance of the $\mathrm{i}^{\text {th }}$ genotype. Genotypes with high values of stability indexes are the best.

Superiority index $\left(P_{i}\right)$. The index was calculated from the sum of squares of the differences between the genotype of interest for the genotype of higher yield in each of the environments, so it represents the mean square of the joint effect of genotypes and GEI. In addition, it determines the adaptability in a broad sense (Lin and Binn, 1988) calculated about the maximum response. A small value of Pi implies general adaptation of a genotype. The calculation formula was the following:

$$
P_{i}=\frac{\sum_{j=1}^{n}\left(\mathrm{Y}_{i j}-\bar{M}_{j}\right)^{2}}{2 n}
$$

Where

$Y_{i j}=$ is the mean yield of the $i^{\text {th }}$ cultivar in the $j^{\text {th }}$ environment

$\bar{M}_{j}=$ is the maximum response observed among all the cultivars in environment $j$.

$\mathrm{n}=$ is the number of environments.

Reliability index $\left(\mathbf{I}_{\mathrm{i}}\right)$. This index was determined following the procedure described by Annichiriaco (2002), based on the distribution of the observed means of TPH across the test environments. The equation used was the following:

$$
I i=m i-Z(P) S i
$$

Where: $m_{i}=$ mean yield; $S_{i}=$ square root of the environmental variance and $\mathrm{Z}_{(\mathrm{P})}=$ Percentile of the normal distribution for a probability value (P). Depending on the level of probability $(\mathrm{P}), \mathrm{Z}_{(\mathrm{P})}$ can assume the following values: 0.675 to $\mathrm{P}=0.75$; 0.840 to $P=0.80 ; 1.040$. $P$ values may vary between 0.95 (for subsistence agriculture in unfavorable cropping regions) to 0.70 for modern agriculture in most favorable regions.

Geometric adaptability index (GAI). The geometric mean can be used as a measure of adaptability:

$$
G A I=\sqrt[E]{(\bar{X} 1)(\bar{X} 2) \ldots(\bar{X} i .)}
$$

Where $\mathrm{X} 1, \mathrm{X} 2$ are the mean yields of the first, second and $\mathrm{I}^{h}$ genotype through environments and $E$ is the number of environments. Genotypes with high GEI are the chosen ones (Pourdad, 2011).

Sustainability Index (SI). The Sustainability Index was estimated according to the equation used by Babarmanzoor et al. (2009).

$$
S I=[(Y-\sigma n) / Y M] x 100
$$

Where

$\mathrm{Y}=\mathrm{TPH}$ mean of a genotype through environments

$\sigma n=$ standard deviation

$\mathrm{YM}=$ Better yield of a genotype in any year or location.

The sustainability index values were divided arbitrarily inside of 5 groups: Very low (until 20 $\%)$, Low (21-40 \%), moderate (41-60\%), high (61$80 \%$ ) and very high (plus of $80 \%$ ).

Association between statistics, indices and yield. A principal components analysis was performed using the rank matrix to determine the degree of association between indices, statistics and the mean yield in TPH. 


\section{RESULTS AND DISCUSSION}

AMMI model. The mean yield in TPH was significantly affected by environmental and genotypic effects. The first two axes of the principal components (CP1 and CP2) of the interaction of the AMMI model were significant $(\mathrm{p}<0.01)$.

The TPH mean of the locations varied between 14.80 (Turbio I) and 20.56 (Matilde). The yields of the clones ranged from 9.82 (CP92-1641) to 27.92 (CR87-339) (Table 2). Significant differences for the GEI show that the response of the varieties was distinct in diverse environments. Rea et al. (2014) note that the GEI reduces the correlation between genotypic and phenotypic values, affecting selection's progress. One of the methods to minimize the GEI is to select stable cultivars using stability analysis.
Yield stability in TPH. Table 4 shows the results of several statistics and stability indices. For the ecovalence and variance of Shukla, the most stable genotypes were CP88-1762, V90-6 and CP92-1641. This similarity in the results of both methods has been demonstrated by Becker and León (1988). The AMMI stability value was estimated according to Purchase et al. (2000). The results showed that the sum of squares of the first two principal components explained $67 \%$ of the data variance. According to the ASV, the genotypes V90-6, CP88-1762 and CP921641 are the most stable, coinciding with the genotypes selected by the ecovalence and Shukla variance methods. Purchase et al. (2000) point out that ASV can be compared with W and $\sigma_{i}^{2}$.

Table 2. Average yield in TPH of eighteen sugarcane genotypes at six environments in two cycles of harvest.

\begin{tabular}{lccccccc}
\hline Variety & Carora & Palmar & Matilde & La Pastora & Turbio I & Turbio II & Mean \\
\hline C 323-68 (T) & 19.90 & 23.61 & 22.74 & 22.88 & 17.35 & 17.72 & 20.70 \\
CP74-2005 (T) & 15.39 & 21.85 & 23.22 & 15.99 & 15.71 & 15.91 & 18.01 \\
CP80-1743 & 13.62 & 16.13 & 22.90 & 19.22 & 15.22 & 17.27 & 17.39 \\
CP80-1827 & 10.54 & 15.49 & 18.47 & 21.86 & 10.92 & 14.13 & 15.23 \\
CP88-1762 & 13.32 & 15.01 & 19.36 & 17.37 & 12.64 & 13.43 & 15.19 \\
CP89-2143 & 18.13 & 16.59 & 21.50 & 20.77 & 15.38 & 12.98 & 17.56 \\
CP89-2377 & 13.64 & 16.14 & 16.99 & 20.88 & 13.97 & 10.38 & 15.33 \\
CP92-1213 & 11.31 & 16.06 & 20.21 & 21.21 & 10.75 & 13.72 & 15.54 \\
CP92-1641 & 9.82 & 14.56 & 14.90 & 13.52 & 11.02 & 10.67 & 12.41 \\
CR83-323 & 18.30 & 17.34 & 19.70 & 18.27 & 15.64 & 17.20 & 17.74 \\
CR87-339 & 25.42 & 27.92 & 27.56 & 25.91 & 24.15 & 23.52 & 25.75 \\
LCP85-384 & 16.10 & 18.52 & 20.05 & 18.27 & 15.85 & 13.11 & 16.98 \\
V90-11 & 14.57 & 16.74 & 24.19 & 19.65 & 13.78 & 15.83 & 17.46 \\
V90-14 & 12.19 & 14.59 & 16.91 & 16.75 & 14.26 & 11.07 & 14.30 \\
V90-2 & 13.63 & 17.24 & 19.91 & 14.08 & 12.27 & 20.75 & 16.31 \\
V90-3 & 18.63 & 15.51 & 20.57 & 17.92 & 13.93 & 16.85 & 17.23 \\
V90-6 & 14.54 & 15.70 & 19.70 & 17.98 & 14.20 & 14.39 & 16.09 \\
V98 76 & 15.94 & 16.45 & 21.14 & 18.01 & 19.44 & 16.31 & 17.88 \\
\hline Mean & 15.28 & 17.52 & 20.56 & 18.92 & 14.80 & 15.29 & 17.06 \\
\hline
\end{tabular}

$(\mathrm{T})=$ Checks 


\section{Indices for stability and yield}

Kang's (1988) rank-sum. The results of six stability indices are presented in Table 3. According to Kang's rank-sum, genotypes with low values are considered the most desirable. This index revealed that the genotypes CR 87-339 and C32-368 (T) had the lowest values and therefore were the most stable and yielding, while those with high values such as the genotypes: CP80-1827, V90-2, CP892377, CP92-1213 were the most unstable.

Stability index (I). The basic element in the index construction is that the genotypes' achievement levels and their stability are quantified by the individual achievement expression relative to the average behavior of the group of genotypes evaluated. Bajpai and Prabhakaran (2000) proposed this index arguing that the rank sum method has its weaknesses due to the heavyweight given to yield. The ranks assigned by the stability index were in increasing order, the genotype with the highest stability index (I) received the rank 1, and the lowest index received the rank 14 of the 18 genotypes evaluated. According to this index, the CP88-1762, V90-6, CR87-339 and C323-68 genotypes were the most stable and CP80-1827, CP89-2377 and CP92-1213 the adapted less.

Table 3. Indices for simultaneous selection of stability and yield in eighteen sugarcane genotypes evaluated in six environments.

\begin{tabular}{lccccccccccccc}
\hline \multicolumn{1}{c}{ Genotipos } & TPH & (W) & $\sigma^{2}{ }^{2}$ & $\begin{array}{c}\text { Score } \\
\text { CP1 }\end{array}$ & $\begin{array}{c}\text { Score } \\
\text { CP2 }\end{array}$ & ASV & RS & $\mathbf{I}$ & $\mathbf{P}_{\boldsymbol{i}}$ & $\mathbf{I}_{\mathbf{i}}$ & GAI & SI (\%) & GSI \\
\hline C 323-68 (T) & 20.7 & 35.5 & 7.3 & 0.7 & 1.38 & 1.5 & 9 & 0.04 & 161.2 & 16.6 & 20.7 & 66.8 & 6 \\
CP 74-2005 (T) & 18.0 & 90.6 & 19.7 & -3.2 & 0.62 & 4.5 & 19 & 0.03 & 383.9 & 13.5 & 17.7 & 54.2 & 17 \\
CP 80-1743 & 17.4 & 41.1 & 8.5 & -0.7 & -2.8 & 2.9 & 17 & 0.03 & 463.6 & 13.1 & 17.2 & 53.6 & 19 \\
CP 80-1827 & 15.2 & 107.9 & 23.6 & 3.9 & -4.1 & 6.8 & 35 & 0.03 & 738.2 & 10.2 & 14.7 & 42.5 & 31 \\
CP 88-1762 & 15.2 & 3.2 & 0.01 & 0.3 & -0.61 & 1.0 & 17 & 5.66 & 703.4 & 10.3 & 15.0 & 48.2 & 18 \\
CP 89-2143 & 17.6 & 52.6 & 11.1 & 2.4 & 2.02 & 3.9 & 17 & 0.03 & 432.4 & 13.5 & 17.3 & 61.1 & 19 \\
CP 89-2377 & 15.3 & 84.1 & 18.2 & 4.8 & 1.84 & 6.9 & 28 & 0.03 & 690.7 & 11.3 & 14.9 & 50.3 & 31 \\
CP 92-1213 & 15.5 & 84.9 & 18.4 & 3.5 & -3.93 & 6.2 & 28 & 0.03 & 691.5 & 10.7 & 15.3 & 46.2 & 28 \\
CP 92-1641 & 12.4 & 17.5 & 3.2 & -0.6 & 0.77 & 1.1 & 21 & 0.03 & 1073.1 & 8.6 & 12.3 & 52.5 & 21 \\
CR 83-323 & 17.7 & 35.7 & 7.3 & -1.9 & 1.44 & 2.9 & 13 & 0.03 & 394.9 & 14.6 & 17.7 & 71.2 & 15 \\
CR 87-339 & 25.8 & 34.2 & 6.9 & -1.3 & 2.61 & 3.2 & 7 & 0.05 & 0.0 & 21.4 & 25.7 & 73.6 & 13 \\
LCP 85-384 & 16.9 & 24.5 & 4.8 & 0.5 & 2.57 & 2.7 & 14 & 0.03 & 467.2 & 12.7 & 16.8 & 54.1 & 16 \\
V 90-11 & 17.5 & 45.7 & 9.6 & 0.3 & -2.74 & 2.8 & 17 & 0.03 & 459.7 & 12.8 & 17.1 & 49.3 & 15 \\
V 90-14 & 14.3 & 24.9 & 4.9 & 1.3 & 1.8 & 2.6 & 22 & 0.03 & 802.5 & 11.4 & 14.8 & 64.3 & 22 \\
V 90-2 & 16.3 & 178.5 & 39.4 & -6.7 & -3.43 & 9.8 & 29 & 0.03 & 600.7 & 11.5 & 16.0 & 51.1 & 29 \\
V 90-3 & 17.2 & 57.9 & 12.3 & -1.9 & 0.51 & 2.7 & 21 & 0.03 & 461.6 & 12.6 & 17.1 & 56.9 & 16 \\
V 90-6 & 16.1 & 2.8 & 0.09 & 0 & 0.1 & 0.1 & 14 & 0.34 & 574.5 & 12.1 & 15.9 & 57.6 & 13 \\
\hline V 98-76 & 17.9 & 63.8 & 13.6 & -1.5 & 1.96 & 2.8 & 17 & 0.03 & 399.2 & 14.1 & 17.8 & 63.4 & 13 \\
\hline
\end{tabular}

$(\mathrm{T})=$ Checks 
Linn and Binn superiority index $\left(\mathrm{P}_{\mathrm{i}}\right)$. This index is a unique measure of stability and yield. Based on this method, the selected genotypes were those with low indices and yields above the general average (Kilic et al., 2010). In this case, the best genotypes were C87-339, C323-68, CP74-2005 (T), CR83-323 and V98-78.

Geometric adaptability index (GAI). This index is based on the geometric mean of the genotype. Genotypes with high GAI values are acceptable (Pourdad, 2011). In this case, the genotypes CR 87-339, C323-68 (T), V98-76 and CR 83-323 were those with the best yields and stability.

Reliability index $\left(\mathrm{I}_{\mathrm{i}}\right)$. To estimate this index, it was assumed that the technological level for agriculture of Venezuela falls between subsistence levels and modern agriculture, where it was taken $(\mathrm{P})=0.8$ corresponding to a value of $\mathrm{Z}(\mathrm{p})=$ 0.84 . This value was inserted in the equation of $\mathrm{I}_{i}$; a genotype is selected if it has high values of $\mathrm{I}_{i}$. In this way, the genotypes: CR87-339, C323-68, CR83-323 and V98-76 were the most outstanding. Gómez-Becerra et al. (2007) selected genotypes of wheat (T.Aestivum) based on this method.

Sustainability Index (SI). The values of this index were arbitrarily divided into five groups, from very low and very high. The genotypes in the high group (61-80\%) of sustainability were CR87-339, CR83323, C323-68, V90-14, V98-76, CP89-2143. The rest of the genotypes were grouped as of moderate sustainability. This index was used successfully by Koli and Prakash (2013) in the selection of rice varieties.

Genotypic stability index (GSI). This index integrates both the AMMI value and the yield in a single selection criterion proposed by Fardshafar (2008). The genotypes with low values of this index are those selected. According to this criterion, the genotypes with the best behavior were C323-68, CR87-339, V98-78 and V90-6.
In the results obtained, it can be observed that when only the stability methods are used, the selected genotypes are not the ones with the best yields; On the other hand, when the selection indices are used, the most yielding genotypes appear among those selected: CR87-339 and C32-362. This demonstrates the importance of considering both stability and yield selecting genotypes when they are evaluated in diverse environments.

\section{Association between different indexes using} main components. An analysis of the principal components of the matrix of ranks of statistics and stability indexes was made to observe the associations between them (Table 4). A biplot with the values of CP1 and CP2 is shown in Figure 1. The two principal components represented $90.8 \%$ of the total variation, distinguishing the indices in three different groups. In group 1 (G1) were located $\mathrm{P}_{i}, \mathrm{GAI}, \mathrm{I}_{\mathrm{i}}$ and the yield in TPH. This group coincided in classifying genotypes CR87-339, C323-68 and V98-76 as the most stable and best performing. The second group (G2) was composed of RS, I, SI and GDI and identified the genotypes CR87-339 and C323-68 as the best. The genotype V98-76 was selected by the GDI and SI indices. The W statistics, Shukla and the AMMI value constituted the third group (G3). According to the statistics, the best genotypes were CP87-1762, V90-6 and CP 9216-41. Group 3 differed in the classification of genotypes to the groups 1 and 2. This is a clear indication of the utility of using indices where both yield and stability are considered in a single criterion. The statistics of Group 3 only measure stability, and there are cases in which the most stable genotype is not the most yield (Mohammadi and Amri, 2008). These results corroborate the findings of other authors searching for approaches that include both stability and yield in a single index for cultivars selection in different environments (Babarmanzoor et al., 2009; Farshadfar et al., 2011; Rao and Prabhakaran, 2005). 
Table 4. Ranks of sugarcane genotypes according to the mean of TPH, stability and stability indexes.

\begin{tabular}{lccccccccccc}
\hline \multicolumn{1}{c}{ Genotipos } & TPH & $\boldsymbol{W}$ & $\sigma^{2}{ }^{2}$ & ASV & RS & $\mathbf{I}$ & $\mathbf{P}_{\boldsymbol{i}}$ & $\mathbf{I}_{\mathbf{i}}$ & GEI & SI & GSI \\
\hline C323-68 & 2 & 7 & 7 & 4 & 2 & 4 & 2 & 2 & 2 & 3 & 1 \\
CP74-2005 & 3 & 16 & 16 & 14 & 11 & 11 & 3 & 6 & 4 & 9 & 9 \\
CP80-1743 & 8 & 9 & 9 & 11 & 6 & 7 & 8 & 7 & 7 & 11 & 11 \\
CP80-1827 & 15 & 17 & 17 & 16 & 18 & 18 & 16 & 17 & 17 & 18 & 17 \\
CP88-1762 & 16 & 1 & 1 & 2 & 6 & 1 & 15 & 16 & 14 & 16 & 10 \\
CP89-2143 & 6 & 11 & 11 & 13 & 6 & 7 & 6 & 5 & 6 & 6 & 11 \\
CP89-2377 & 14 & 14 & 14 & 17 & 15 & 16 & 13 & 14 & 15 & 14 & 17 \\
CP92-1213 & 13 & 15 & 15 & 15 & 15 & 16 & 14 & 15 & 13 & 17 & 15 \\
CP92-1641 & 18 & 3 & 3 & 3 & 12 & 13 & 18 & 18 & 18 & 12 & 13 \\
CR83-323 & 5 & 8 & 8 & 10 & 3 & 6 & 4 & 3 & 5 & 2 & 5 \\
CR87-339 & 1 & 6 & 6 & 12 & 1 & 3 & 1 & 1 & 1 & 1 & 2 \\
LCP85-384 & 10 & 4 & 4 & 6 & 4 & 5 & 10 & 9 & 10 & 10 & 7 \\
V90-11 & 7 & 10 & 10 & 8 & 6 & 7 & 7 & 8 & 8 & 15 & 5 \\
V90-14 & 17 & 5 & 5 & 5 & 14 & 13 & 17 & 13 & 16 & 4 & 14 \\
V90-2 & 11 & 18 & 18 & 18 & 17 & 15 & 12 & 12 & 11 & 13 & 16 \\
V90-3 & 9 & 12 & 12 & 7 & 12 & 11 & 9 & 10 & 9 & 8 & 7 \\
V90-6 & 12 & 2 & 2 & 1 & 4 & 2 & 11 & 11 & 12 & 7 & 2 \\
\hline V98-76 & 4 & 13 & 13 & 9 & 6 & 7 & 5 & 4 & 3 & 5 & 2 \\
\hline
\end{tabular}

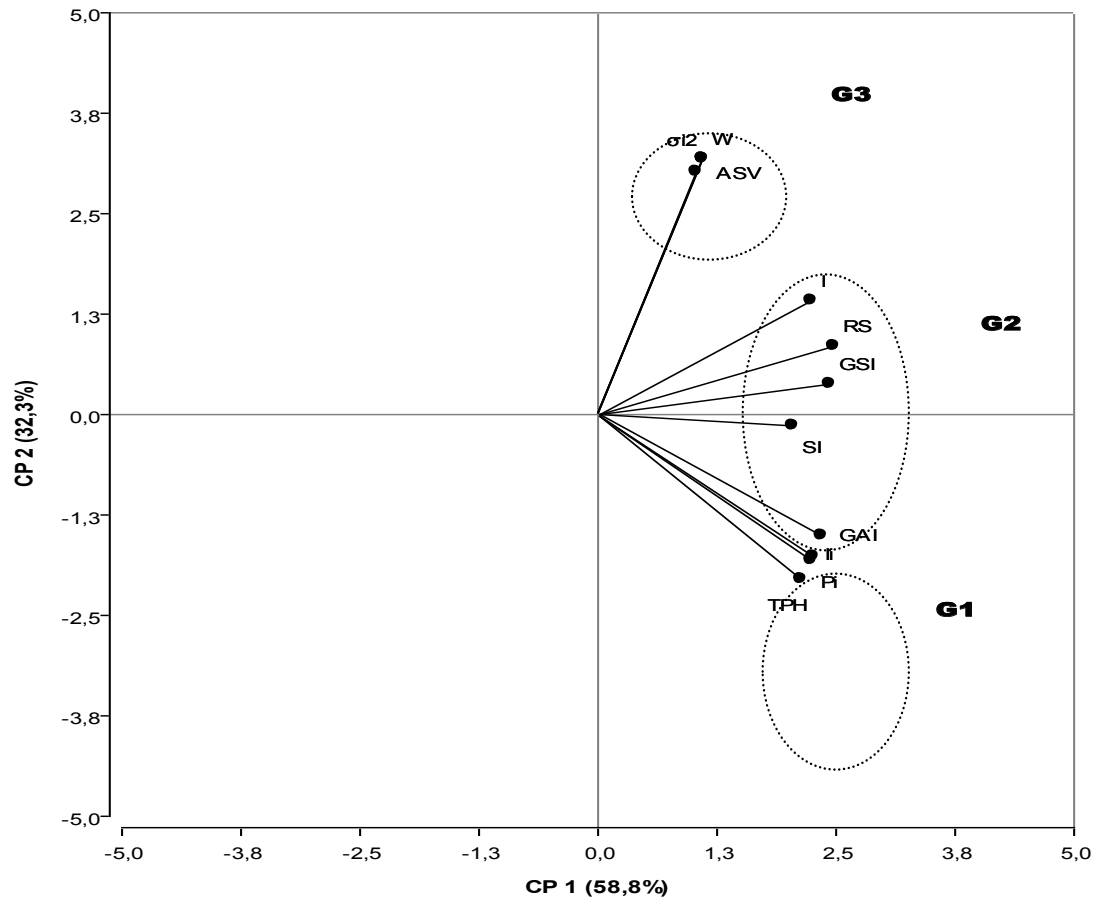

Figure 1. Biplot of ranks for TPH, stability and stability indexes in sugarcane genotypes. 


\section{CONCLUSIONS}

The selection of cultivars for high yield and stability is an important component of the sugarcanebreeding program, where environments are variable and unpredictable. According to this work, the genotypes most stable and best yields were CR87-339, C323-68 and V98-76.

\section{ACKNOWLEDGMENTS}

The authors thank the technical staff of the National Agricultural Research Institute (Yaracuy) and the Carora, La Pastora, Turbio, El Palmar and Matilde Mills for the support provided in the development of all the research activities.

Conflict of interests: The authors declare that there is no conflict of interest.

\section{BIBLIOGRAPHIC REFERENCES}

Annicchiarico, P. (2002). Defining strategies and yield stability targets in breeding programs, in MS Kang, (E d.). Quantitative Genetics, Genomics and PlantBreeding (pp.365-383). Wallingford, England: CABI.

Babarmanzoor, A.; Tariq, M. S.; Ghulam A.; Muhammad, A. (2009). Genotype $\times$ environment interaction for seed yield in Kabuli Chickpea (Cicer arietinumL.) genotypes developed through mutation breeding. Pakistan Journal of Botany. 41(4): 1883-1890.

Bajpai, P. K.; Prabhaaran, V. T. (2000). A new procedure of simultaneous selection for high yielding and stable crop genotypes. Indian Journal of genetics \& Plant Breeding. 60(2):141-146.

Becker, H. C.; Leon, J. (1988). Stability analysis in plant breeding. Plant Breeding. 101: 1-23.

Crossa, J.; Yang, C.; Cornelius, P. L. (2004). Studying crossover genotype $\times$ environment interaction using linear-bilinear models and mixed models. Journal of Agricultural, Biological and Environmental Statistics. 9(3): 362-380.
Eberhart, S. A.; Russell, W. A. (1966). Stability parameters for comparing varieties. Crop Science. 6(1): 36-40. doi: 10.2135/ cropsci1966.0011183X $000600010011 \mathrm{x}$

Farshadfar, E. (2008). Incorporation of AMMI stability value and grain yield in a single non parametric index (GSI) in bread wheat. Pakistan Journal of Biological Sciences, 11 (14): 1791-1796. doi:10.3923 / pjbs.2008.1791.1796

Farshadfar, E.; Mahmodi, N.; Yaghotipoor, A. (2011). AMMI stability value and simultaneous estimation of yield and yield stability in bread wheat (Triticum aestivum L.) Australian Journal of Crop Science. 5(13): 1837-1844.

Gómez-Becerra, H. F.; Morgounov, A.; Abugalieva, A. (2007). Evaluation of grain yield stability, reliability and cultivate recommendations in spring wheat (Triticum aestivum 1.) From Kazakhstan and Siberia. Journal of Central European Agriculture. 7(4): 649660.

Kang, M. S.; Pham, H. N. (1991). Simultaneous selection for high yielding and stable crop genotypes. Agronomy Journal. 83(1):161-165. doi: 10.2134/ag ronj1989.00021962008100040020x

Kilic, H.; Akura, M.; Aktas, H. (2010). Assessment of parametric and non-parametric methods for selecting stable and adapted durum wheat genotypes in multi-environments. Notulae Botanicae Hortic Agrobotanici Cluj. 38(3):271-279.

Koli, N.; Prakash, C. (2013). Sustainability index as an aid for determination of genotypic stability in aromatic rice (Oryza sativa L.) under transplanted condition in south-eastern plain zone of Rajasthan. Journal of Rice Research. 6(1): 1-6.

Lin, C.S.; Binns, M. R. (1988). A superiority measure of cultivating performance for cultivating $\mathrm{x}$ location data, Canadian Journal of Plant Science. 68(1): 193198. doi: https://doi.org/10.4141/cjps88-018

Lin, C.S.; Binns, M. R.; Lefkovitch, L. P. (1986). Stability analysis: where do we stand? Crop Science. 26(5): 894-900. doi:10.2135/ cropsci1986.0011183X002 $600050012 x$ 
Mohammadi, R.; Amri, A. (2008). Comparison of parametric and non-parametric methods for selecting stable and adapted durum wheat genotypes in variable environments. Euphytica. 159(3): 419-432. doi: https://doi.org/10.1007/ s10681-007-9600-6

Pérez-Guerra, E.; Oliveira, R.; Daros, E.; Zumbón, J.; Ido, 0.; Bespalhok Filho, J. (2009). Stability and adaptability of early maturing sugarcane clones by AMMI analysis. Crop Breeding and Applied Biotechnology. 9: 260-267. doi: 10.12702/19847033.v09n03a08

Pourdad, S. S. (2011). Repeatability and relationships among parametric and non-parametric yield stability measures in safflower (Carthamus tinctorius L.) genotypes. Crop Breeding Journal. 1(2): 109-118.

Purchase, J. L.; Hatting, H.; Van Deventer, C.S. (2000). Genotype $\mathrm{x}$ environment interaction of wheat in South Africa: Stability analysis of yield performance. South African Journal of Plant and Soil. 17(3): 101107. https://doi.org/10.1080/02571862.2000.106 34878

Rao, A. R.; Prabhakaran, V. T. (2005). Use of AMMI in simultaneous selection of genotypes for yield and stability. Journal of the Indian Society of Agricultural Statistics. 59(1): 76-82.

Rea, R.; De Sousa-Vieira, 0.; Ramón, M.; Alejos, G.; Díaz, A.; George, J. (2014). Selección simultánea para rendimiento y estabilidad en genotipos de caña de azúcar en la región centro-occidental de Venezuela. Bioagro. 26(3): 153-158.

Rea, R.; De Sousa-Vieira, 0.; Díaz, A.; Ramón, M.; Briceño, R.; George, J.; Demey, J. (2015). Assessment of yield stability in sugarcane genotypes using nonparametric methods. Agronomía Colombiana. 33(2): 131-138. doi: https://doi.org/10.15446/agron. colomb.v33n2.49324

Scortecci, K. C.; Creste, S.; Calsa, J. T.; Xavier, M. A.; Landell, M. G. de A.; Figueira, A. V. de 0.; Benedito, V. A. (2012). Chapter 12 Challenges, opportunities and recent advances in sugarcane breeding. In Plant breeding. Rijeka: InTech.

Shukla, G. K. (1972). Some statistical aspects of partitioning genotype-environmental components of variability. Heredity. 29(2): 237-245. doi: https:// doi.org/10.1038/hdy.1972.87

Wricke, G. (1962). On a method of understanding the biological diversity in field research. Zeitschrift für Pflanzenzucht. 47(1): 92-96. 


\title{
Environmental offering and coffee cup quality (Coffea arabica L.) Var. Castillo in southern Colombia
}

\author{
Oferta ambiental y calidad de taza de café (Coffea arabica L.) Var. \\ Castillo en el sur de Colombia
}

Claudia Patricia Criollo-Velásquez ${ }^{1}$; Johana Alixa Muñoz-Belalcazar²; Tulio César Lagos-Burbano ${ }^{3}$

\begin{tabular}{l}
\hline \multicolumn{2}{c}{ ARTICLE DATA } \\
\hline 1 Agroindustrial Engineer, M.Sc.; Grupo de \\
Investigación en Producción de Frutales Andinos, \\
Universidad de Nariño, Pasto, Colombia, ingcrivel@ \\
gmail.com \\
2 Agronomy Engineer, M.Sc. Grupo de Investigación \\
en Producción de Frutales Andinos, Universidad \\
de Nariño, Pasto, Colombia, mjohannaalixa@ \\
gmail.com \\
3 Associate professor. Ph.D. Facultad de Ciencias \\
Agrícolas, Universidad de Nariño, Pasto, Colombia, \\
tclagosb@udenar.edu.co
\end{tabular}

Cite: Criollo-Velásquez, C.; Muñoz-Belalcazar, J.; Lagos-Burbano, T. (2020). Environmental factors affecting coffee (Coffea arabica L.) Var. Castillo quality in Colombia Southern. Revista de Ciencias Agrícolas. 37(2): 78-90.

https://doi.org/10.22267/rcia.203702.140

Received: 07 october 2020.

Acepted: 10 december 2020.

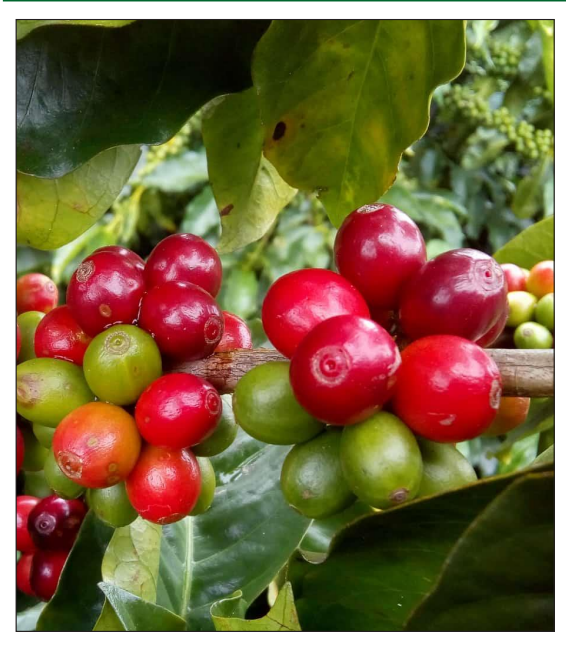

\section{ABSTRACT}

The determinant factors of coffee cup quality are highly variable and depend on their interaction with coffee production and benefit. This study aimed to analyze soil and climatic factors and their association with the cup quality of Castillo coffee variety of three to five years of age from production units in ecotypes 220A and 221A of the Department of Nariño. The study farms were located in three different altitudinal ranges: $\leq 1500 \mathrm{~m}$, between 1501 and $1700 \mathrm{~m}$, and $>1700 \mathrm{~m}$. Soil, climate, and coffee cup quality variables were analyzed through principal component analysis and cluster analysis. A low level of association was found between climatic and soil nutritional factors and coffee cup quality. Soil $\mathrm{Mn}, \mathrm{Fe}$, and $\mathrm{Cu}$ contents showed the highest association levels with cup quality, indicated by an average score of 80.89 . The highest values of photosynthetically active radiation -PAR- and thermal amplitude were found in La Unión - Nariño, and these variables were associated with the group that obtained the highest cup quality score (82.58). Cup quality was not associated with elevation since the highest scores (85.5 and 82.33) were obtained from production units located at $\leq 1500$ m.a.s.l. and $>1700$ m.a.s.l, respectively.

Keywords: score; quality; ecotypes; soil; climate; multivariate analysis.

\section{RESUMEN}

Los factores determinantes de la calidad de taza de café son muy variables y dependen de la interacción de los relacionados con su producción y beneficio. El presente trabajo se orientó al análisis de los factores de suelo y clima y su relación con la calidad de taza de café variedad Castillo de tres a cinco años de edad en unidades productivas de los ecotopos $220 \mathrm{~A}$ y $221 \mathrm{~A}$ del departamento de Nariño. Las fincas de estudio se ubicaron en tres diferentes rangos altitudinales: $\leq 1500 \mathrm{~m}$, entre 1501 y $1700 \mathrm{my}>1700 \mathrm{~m}$. Las variables de suelo, clima y calidad de taza se sometieron a los Análisis de 
Componentes Principales y Agrupamiento. Se detectó un bajo nivel de asociación de los factores contenidos nutricionales del suelo y climáticos con la calidad de taza. Los contenidos de $\mathrm{Mn}$, Fe y Cu en el suelo fueron los que mostraron un mayor nivel de asociación con la calidad de taza con un promedio de 80,89. En el municipio de La Unión se presentaron los mayores valores de radiación fotosintéticamente activa-RFA y amplitud térmica los cuales estuvieron relacionados con el grupo que se caracterizó por tener altos puntajes de calidad de taza $(82,58)$. Los puntajes de calidad de taza no presentaron una tendencia a asociarse con la altitud; es así como los mayores puntajes $(85,5$ y 82,33$)$ se encontraron en unidades productivas ubicadas $\mathrm{a} \leq 1500 \mathrm{msnm}$ y $>1700 \mathrm{msnm}$ respectivamente.

Palabras clave: puntaje; calidad; ecotopos; suelo; clima; análisis multivariado.

\section{INTRODUCTION}

Colombian coffee transitioned from being unique due to its overall characteristics to have quality attributes determined by agroecological conditions associated with the coffee variety, benefit process, and growing region. Additionally, the coffee origin is important for positioning on national and international markets (Raynolds, 2009; Sepúlveda et al., 2013). The factors that affect cup quality are highly variable and represent a bottleneck for creating protocols to obtain quality products. Accordingly, Orozco et al. (2011) determined an unclear association between variety, elevation, soil, and cup quality. The characteristics that define cup quality are determined by a series of physical and chemical variables, such as color, characteristic diameter, equatorial and polar firmness, fresh and dry weight, moisture content, fresh, dry weight ratio, titratable acidity, soluble solids, and $\mathrm{pH}$ of the pulp, as well as organoleptic traits such as aromatic intensity, bitterness, body, aroma, and overall standard (Moreno, 2007).

Coffee grain yield, chemical composition, and physical characteristics can be modified or limited by factors such as temperature (i.e., as a result of altitudinal effects) that prolong maturity of the coffee berry, thus favoring grain-filling and cup quality. Furthermore, other relevant factors include the origin of the soil and fertility, atmospheric conditions, harvest time and distribution, moisture content of the coffee berry, and collection methods and quality (Montilla et al., 2008; Suárez et al., 2015).

The selection of the components of the Castillo variety involved an assessment of the physical and organoleptic beverage's attributes concerning the genotype. A descriptive analysis of its components was used to identifying the genotypic groups that contribute to its sensory characteristics (Alvarado et al., 2009).

The maturation process involves physico-chemical changes in the coffee berry. Marín et al. (2003) determined that the physical changes most associated with fruit maturation were removal force and equatorial and polar firmness since these variables decreased as the berries matured. The best-scored cup was obtained from semi-ripe, ripe, and over-ripe berries, while unripe green and dry berries received low quality scores. The best coffee cup quality is derived from adequately processed ripe berries, reflected by the flavor and aroma (Puerta-Quintero, 2000a).

A comparison between grains developed under shade and sun exposure indicated that the former display greater development of the periplasm, which contributes to grain size and reduced sucrose and sugar contents that delay fruit maturation (Geromel et al., 2008).

Quality is also associated with specialty; therefore, the coffee must meet characteristics associated 
with a particular flavor and be originated from outstanding ecological niches, where crops are subjected to strict management standards. For these reasons, the consumer is willing to pay a higher price (Castro et al., 2004). According to Farfán (2007), specialty Colombian specialty are characterized by their excellent quality, consistency in their physical and sensory properties, benefit, and preparation.

Ramos and Criollo (2017) state that cup quality is a multifactorial variable. These authors determined that elevation does not directly affect quality, although it is inversely related to the presence of the coffee berry borer, low phosphorous content, and reduced fermentation (16-17h) and drying (20-25h sunlight) times, which were associated with higher quality scores.

In the international market, coffee quality is defined by physical attributes such as size, shape, color, and uniformity, as well as organoleptic traits such as acidity, body, aroma, flavor, roasting, and visual features (i.e., color and clarity of the infusion) (Estrella and Chaves, 2008; Céspedes, 2012). These attributes and characteristics are unique to each variety and, along with benefit, are responsible for the final quality of the coffee beverage (Alvarado and Puerta, 2002). The Castillo variety displays grain and quality traits similar to or better than other crop varieties traditionally grown. Furthermore, the quality characteristics of Caturra, the Timor hybrid, and Castillo are highly homogenous. The beverages show body, slight bitterness, pronounced aroma, and acidity for medium degrees of roasting. Coffee processing under similar and optimal conditions during benefit, roasting, and beverage preparation do not show significant differences in cup quality (Alvarado et al., 2009; Alvarado et al., 2005).
The contrasting results among different authors has not allowed clearly establishing the environmental requirements and optimal pre and post-harvest managements to achieve long-term high-quality standards. Therefore, coffee-growers who produce high-quality coffee are currently hesitant about the factors that contribute to this attribute and, thus, struggle when attempting to maintain the high-quality levels required by specialty markets.

This research aimed to characterize the edaphoclimatic offer for Castillo coffee variety in ecotypes $220 \mathrm{~A}$ and $221 \mathrm{~A}$ of the Department of Nariño and to establish the association between environmental offer and cup quality.

\section{MATERIALS AND METHODS}

This study was conducted in farms growing coffee trees of the Castillo variety in ecotypes 220A and 221A of the Department of Nariño. Ecotype 220A is located in the Patía river basin and the subbasins of Juanambú and Mayo rivers between $1^{\circ} 21^{\prime}$ and $1^{\circ} 42^{\prime} \mathrm{N}$ at 1300 to 1800 m.a.s.l., with an annual precipitation ranging from 1700 to $1900 \mathrm{~mm}$. This zone is characterized by shallow soils of volcanic origin (i.e., from Doña Juana volcano), with low organic matter content, medium natural fertility, and susceptibility to erosion. The coffee crops are characterized by scattered shade trees. Moreover, ecotype 221A is found in the Guitara river basin located between $1^{\circ} 05^{\prime}$ and $1^{\circ} 36^{\prime} \mathrm{N}$ at 1400 to 2100 m.a.s.l., with annual precipitation ranging from 1400 to $1700 \mathrm{~mm}$. It is characterized by shallow soils derived from volcanic ash, with low moisture retention capacity and susceptibility to erosion (Gómez et al., 1991). Traditional crop management is related to family economy (Burgos, 2015). 
In this study, 82 coffee growers with young coffee crops (3-5 years) of the Castillo variety were selected, who were located at three altitudinal strata: high $(\mathrm{H})$, medium $(\mathrm{M})$, and low (L) Among these coffee growers, 12 were chosen as representatives of the two ecotypes (six per ecotype as quota) using non-probabilistic quota sampling (Otzen and Manterola, 2017). In each ecotype, two coffee farms were selected per altitudinal strata (Table 1).

Each sampling unit consisted of crops with different agronomic practices and conventional (chemical) fertilization. Furthermore, at each unit, passport information was recorded and the location was georeferenced using a Garmin global positioning system device.

The edaphoclimatic variables analyzed were maximum and minimum temperatures, relative humidity, photosynthetically active radiation, and precipitation. These data were obtained from records for a single year from meteorological stations (Spectrum Technologies, Inc. Model: 2900ET Weather Station), located at the experimental farms objective of the SGR project entitled "Evaluation of the effect of shade by different tree species on the agronomic behavior and quality of coffee, Consacá, Nariño, Occidente".

Soil trait data related to $\mathrm{pH}$, cation exchange capacity (CEC), organic matter (OM), nitrogen (N), phosphorus $(\mathrm{P})$, potassium $(\mathrm{K})$, calcium $(\mathrm{Ca})$, boron (B), iron (Fe), zinc $(\mathrm{Zn})$, copper $(\mathrm{Cu})$, manganese $(\mathrm{Mn})$, magnesium $(\mathrm{Mg})$, carbon $(\mathrm{C})$ and sulfur (S) were obtained from the analyses carried out by specialized laboratories of the Universidad de Nariño, which determined.

Table 1. Ecotype and altitudinal distribution of the farms selected in this research.

\begin{tabular}{cclll}
\hline Ecotype & Local & Municipality & \multicolumn{1}{c}{ Farm } & Elevation (m a.s.l.) \\
\hline \multirow{2}{*}{$220 \mathrm{~A}$} & 1 & La Unión & La Onda & $>1700(\mathrm{H})$ \\
& 2 & La Unión & El Oasis & $>1700(\mathrm{H})$ \\
& 3 & La Unión & I.E.D.R. El Sauce & $1501-1700(\mathrm{M})$ \\
& 4 & La Unión & San José & $1501-1700(\mathrm{M})$ \\
& 5 & La Unión & El Retiro & $\leq 1500(\mathrm{~L})$ \\
& 6 & La Unión & El Porvenir & $\leq 1500(\mathrm{~L})$ \\
& 7 & Sandoná & Las delicias & $>1700(\mathrm{H})$ \\
& 8 & La Florida & Altos del Carmen & $>1700(\mathrm{H})$ \\
& 9 & Sandoná & Villa María & $1500-1700(\mathrm{M})$ \\
& 10 & Consacá & El Paraíso & $1500-1700(\mathrm{M})$ \\
& 11 & Consacá & El Fantasio & $\leq 1500(\mathrm{~L})$ \\
& 12 & La Florida & La joya & $\leq 1500(\mathrm{~L})$ \\
\hline
\end{tabular}


The traits for cup quality were determined based on physical and sensory analyses. They included: fragrance/aroma (Fr/Ar), flavor (Fl), residual flavor (Fr), acidity (Ac), body (Bd), uniformity (Un), balance $(\mathrm{Bl}), \mathrm{pH}$, score assigned by the taster (St), and total score (TS). The Specialty Coffee Association of America-SCAA (2015) established a classification according to the score obtained: $<80$ below the score for a specialty coffee, 80 - 84.99 very good, 85- 89.99 excellent, and 90 - 100 exceptional. The analyses were conducted according to the norms and procedures of Juancafé private laboratory in the city of Pasto, Nariño, which follows the standard protocols of the Specialty Coffee Asociation (SCAA) and the norms of the Federación Nacional de Cafeteros de Colombia, and it has $Q$ grader tasters certified by the Coffee Quality Institute.

During the main harvest, between April and June, 10 kilograms of coffee cherry were manually collected at each farm and processed through traditional methods. The beans were sun dried at each farm. When the grains reached $10-12 \%$ humidity, three random samples of $500 \mathrm{~g}$ of dry parchment coffee- DPC were taken to Juancafé private laboratory for their physical and sensory analyses (i.e., tasting process).

All of the variables were organized and categorized for the multivariate principal component analysis (PCA), which provides a summarized multivariate description of study conditions, individuals, or sites and allows comprehending the structure of the associations across the variables (Ávila et al., 2015). Next, a clustering analysis was conducted based on criterion Ward (1963), which is an appropriate statistical method to group variables so that the inertia within groups is minimum and between groups is maximum. The multivariate and cluster analyses were done with the SPAD- 6.3 software.

\section{RESULTS AND DISCUSSION}

The cup quality scores varied between 76.50 and 85.50 (Table 2). Puerta-Quintero et al. (2016) indicate that lower temperatures and elevations above $1600 \mathrm{~m}$ promote better conditions for healthy coffee production. Furthermore, low temperatures allow for natural and controlled fermentation; however, this is not enough to determine cup quality. In contrast, this study found that the highest cup quality was obtained at low elevation $(\leq 1500$ m.a.s.l.) in El Retiro farm in ecotype 220A. In this regard, Lara and Vaast (2007) state that elevation can significantly influence the biochemical composition and physical and sensory quality of the coffee cup. Ramos and Criollo (2017) found a low correlation (-0.42) between elevation and cup quality. Similarly, Cruz et al. (2017) did not find differences in cup quality in response to the altitudinal range (1300 and 1800 m.a.s.l.). Therefore, coffee cup quality is not determined by one or a few variables but is rather the result of the entire production and benefits processes (Aristizabal and Duque, 2006), as confirmed by Orozco et al. (2011). 
Table 2. Behavior of sensory variables: fragrance/aroma (Fr/Ar), flavor (Fl), residual flavor (Fr), acidity (Ac), body (Bd), uniformity (Un), balance (Bl), pH, score assigned by the taster (St), and total score (TS), assessed for determining coffee cup quality in Nariño.

\begin{tabular}{llccccccccccc}
\hline Ecotype & Farm & $\begin{array}{c}\text { Altitudinal } \\
\text { range }\end{array}$ & pH & Fr/-Ar & Fl & Fr & Ac & Bd & Un & Bl & St & TS \\
& & & & & & & & & & & \\
\hline \multirow{2}{*}{ 220A } & La Onda & A & 4.43 & 7.67 & 7.50 & 7.33 & 7.50 & 7.50 & 7.50 & 7.67 & 7.67 & 80.33 \\
& El Oasis & A & 4.67 & 7.17 & 7.00 & 7.00 & 7.00 & 7.00 & 7.00 & 7.17 & 7.17 & 76.50 \\
& I.E.D.R. & M & 4.47 & 7.50 & 7.00 & 7.17 & 8.17 & 7.50 & 7.50 & 7.83 & 7.83 & 80.50 \\
& San José & M & 4.43 & 7.67 & 7.17 & 7.17 & 8.33 & 7.33 & 7.33 & 7.83 & 7.83 & 80.67 \\
& El Retiro & $\mathrm{B}$ & 4.43 & 8.17 & 8.00 & 7.67 & 9.17 & 8.00 & 7.83 & 8.33 & 8.33 & 85.50 \\
& El Porvenir & $\mathrm{B}$ & 4.47 & 7.00 & 7.00 & 7.17 & 9.17 & 7.33 & 7.33 & 7.33 & 7.33 & 79.67 \\
\hline \multirow{2}{*}{ 221A } & Las delicias & $\mathrm{A}$ & 4.60 & 7.50 & 7.50 & 7.33 & 9.17 & 7.50 & 7.67 & 7.83 & 7.83 & 82.33 \\
& A. del Carmen & $\mathrm{A}$ & 4.57 & 7.67 & 7.50 & 7.33 & 7.67 & 7.50 & 7.67 & 7.83 & 8.00 & 81.17 \\
& Villa María & $\mathrm{M}$ & 4.47 & 7.83 & 7.50 & 7.50 & 7.83 & 7.50 & 7.50 & 8.00 & 8.00 & 81.67 \\
& El Paraíso & $\mathrm{M}$ & 4.70 & 7.50 & 7.50 & 7.50 & 7.50 & 7.33 & 7.33 & 7.50 & 7.50 & 79.67 \\
& El Fantasio & $\mathrm{B}$ & 4.47 & 7.67 & 7.50 & 7.33 & 7.83 & 7.33 & 7.33 & 7.83 & 7.83 & 80.67 \\
& La Trasjoya & $\mathrm{B}$ & 4.47 & 7.17 & 7.50 & 7.00 & 7.17 & 7.17 & 7.00 & 7.17 & 7.17 & 77.33 \\
\hline Max & & & 4.70 & 8.17 & 8.00 & 7.67 & 9.17 & 8.00 & 7.83 & 8.33 & 8.33 & 85.50 \\
Min & & & 4.43 & 7.00 & 7.00 & 7.00 & 7.00 & 7.00 & 7.00 & 7.17 & 7.17 & 76.50 \\
SD & & & 0.09 & 0.31 & 0.28 & 0.19 & 0.74 & 0.23 & 0.24 & 0.33 & 0.34 & 2.19 \\
\hline
\end{tabular}

$\mathrm{SD}=$ standard deviation.

The PCA of the soil and cup quality variables (Table 3) showed that the first three components explain $77.24 \%$ of the total data variability. The first component, accounting for $35.70 \%$ of the variability, comprised variables $\mathrm{P}, \mathrm{Ca}, \mathrm{Zn}$, and $\mathrm{B}$ with correlation factors (CF) between -0.81 and -0.89. The second component, contributing to $27.19 \%$ of the variance, was mainly composed of variables $\mathrm{N}$ and $\mathrm{C}$, with $\mathrm{CF}$ of 0.84 and 0.82 , respectively. The highest $\mathrm{CF}$ for component 3 was obtained for the variable $\mathrm{S}$ (sulfur content), indicated by a value of -0.81 .
Table 3. Factor-variable correlations and contribution to variability of the first three principal components associated with soil variables and cup quality.

\begin{tabular}{lccc}
\hline \multirow{2}{*}{\multicolumn{1}{c}{ Variable }} & \multicolumn{3}{c}{ Factor } \\
\cline { 2 - 4 } & $\mathbf{1}$ & $\mathbf{2}$ & $\mathbf{3}$ \\
\hline Soil pH & -0.66 & -0.06 & -0.65 \\
Organic matter & -0.51 & 0.73 & 0.33 \\
Phosphorous & -0.89 & 0.13 & 0.14 \\
CEC & -0.43 & 0.52 & 0.38 \\
Calcium & -0.81 & -0.08 & -0.51 \\
Magnesium & -0.66 & -0.12 & -0.70 \\
Potasium & -0.77 & 0.16 & 0.18 \\
Iron & -0.59 & -0.71 & 0.20 \\
Manganese & -0.22 & -0.62 & -0.16 \\
Copper & -0.61 & -0.72 & 0.06 \\
\hline
\end{tabular}


Table 4 continued

\begin{tabular}{lccc}
\hline \multirow{2}{*}{\multicolumn{1}{c}{ Variable }} & \multicolumn{3}{c}{ Factor } \\
\cline { 2 - 4 } & $\mathbf{1}$ & $\mathbf{2}$ & $\mathbf{3}$ \\
\hline Zinc & -0.89 & -0.30 & 0.12 \\
Boron & -0.82 & -0.11 & 0.42 \\
Nitrogen & -0.48 & 0.84 & 0.02 \\
Carbon & -0.43 & 0.82 & -0.15 \\
Sulfur & 0.22 & 0.35 & -0.81 \\
Density & 0.08 & -0.74 & -0.01 \\
Cup quality & -0.07 & -0.45 & 0.19 \\
\hline Eigenvalue & 6.07 & 4.62 & 2.44 \\
PV (\%) & 35.7 & 27.19 & 14.36 \\
CPV (\%) & 35.7 & 62.89 & 77.24 \\
\hline
\end{tabular}

$\mathrm{PV}=$ percentage of the variance; $\mathrm{CPV}=$ cumulative percentage of the variance.

The highest CF for cup quality was observed in component 2 with a negative direction, and it was shared by iron and soil density, which contributed most to this component. This negative direction and high contribution of iron (Table 3) confirm the findings reported in Mexico by Rosas et al.
(2008), who demonstrated a positive influence of this element on the fragrance of the infusion, being able to identify subgroups, including nuts, chocolates, florals, caramels, fruits, and phenolics. Furthermore, they reported a negative contribution of $\mathrm{Cu}$ on the intensity of the acidity.

The classification analysis identified three groups. The first group comprised estates 1, 4, 2, 3,12 , and 10 ; the second group was composed of estates 5,6 , 8,9 , and 11; and group 3 comprised estate 7 , which was far away from the others (Figure 1).

The soils of the first group of estates showed significant differences $(\mathrm{p}<0.05)$ in $\mathrm{Mn}$ content $(30 \mathrm{mg} / \mathrm{kg})$, higher density $(1.07 \mathrm{~g} / \mathrm{cc})$, higher $\mathrm{Cu}$ content $(3.72 \mathrm{mg} / \mathrm{kg})$, and higher Fe content $(138.67 \mathrm{mg} / \mathrm{kg})$ than the overall means of the study population $(16.97 \mathrm{mg} \mathrm{Mn} / \mathrm{kg}$, density of $1.06 \mathrm{mg} / \mathrm{kg}, 2.66 \mathrm{mg} \mathrm{Cu} / \mathrm{kg}$, and $109.51 \mathrm{mg} \mathrm{Fe} / \mathrm{kg}$ ). Additionally, these soils showed organic matter $(3.44 \%)$, nitrogen $(0.13 \%)$, and carbon $(1.87 \mathrm{cmol} / \mathrm{kg})$ contents below the overall means $(4.63 \%, 0.19 \%$, and $2.81 \mathrm{cmol} / \mathrm{kg}$, in the same order).

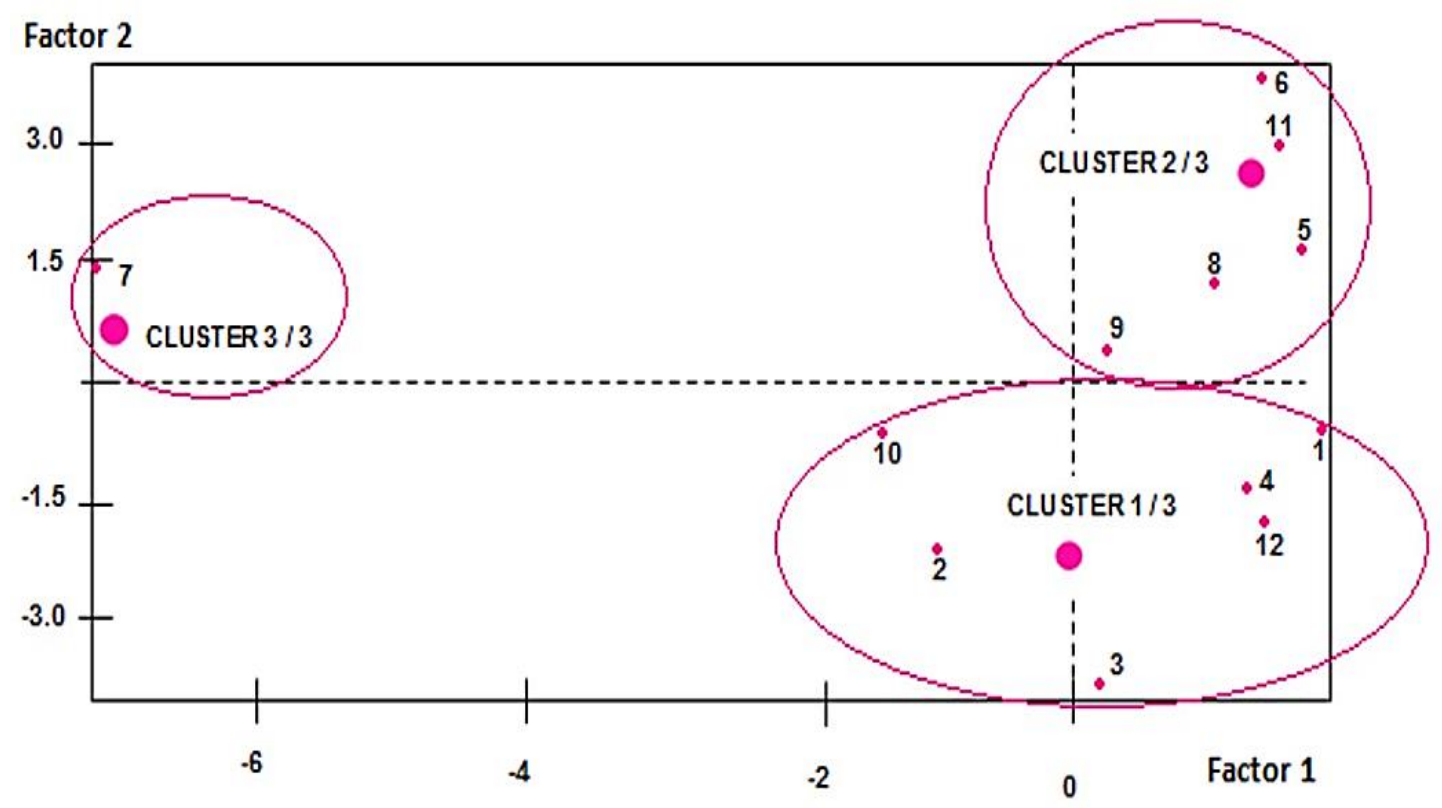

Figure 1. Distribution of the first two principal components for the estates analyzed based on the soil factor and the three groups identified in the classification analysis. 
Group 2 was characterized by higher nitrogen $(0.23 \%)$ and carbon $(3.61 \mathrm{cmol} / \mathrm{kg})$ contents than the overall means $(0.19 \%$ and $2.81 \mathrm{cmol} / \mathrm{Kg}$, in the same order). Furthermore, this group showed lower density values $(0.92 \mathrm{~g} / \mathrm{cc})$ and $\mathrm{Zn}(0.65 \mathrm{mg} / \mathrm{Kg})$, $\mathrm{Mn} \quad(2.29 \mathrm{mg} / \mathrm{Kg}), \quad \mathrm{Cu}(0.91 \mathrm{mg} / \mathrm{Kg})$, and $\mathrm{Fe}$ $(58.02 \mathrm{mg} / \mathrm{Kg})$ contents in contrast to the overall means $(1.00 \mathrm{~g} / \mathrm{cc}, 2.56 \mathrm{mg} \mathrm{Zn} / \mathrm{Kg}, 16.97 \mathrm{mg} \mathrm{Mn} / \mathrm{Kg}$, $2.66 \mathrm{mg} \mathrm{Cu} / \mathrm{Kg}$, and $109.51 \mathrm{mg} \mathrm{Fe} / \mathrm{Kg}$.

Group 3 comprises estate 7 and showed values greater than the overall mean for most variables analyzed, except for Mn $(12.2 \mathrm{mg} / \mathrm{Kg}), \mathrm{S}(2.4 \mathrm{mg} / \mathrm{Kg})$, density $(0.94 \mathrm{~g} / \mathrm{Kg})$, and cup quality score (79.67\%); this last variable was very similar to the overall mean of the population analyzed (80.5\%). Suárez et al. (2015) indicated a high association between the sensory attributes of cup quality and the chemical characteristics of the soil; furthermore, the authors determined that acid soils with high $\mathrm{Fe}$ and $\mathrm{Al}$ contents lead to intermediate and high-quality coffee cups. The same study reported that low cup quality was associated with moderately acid soils with high $\mathrm{Cu}, \mathrm{Zn}, \mathrm{S}$ contents, and low $\mathrm{Ca}$ and $\mathrm{Mg}$ contents. Alternatively, they reported a negative relationship between cup acidity and Ca content and a positive correlation between fragrance/aroma and soil $\mathrm{K}$, $\mathrm{Na}$, and $\mathrm{Al}$ contents.

The first two PC groups, which account for $91.6 \%$ of the population, arrange the estates close to the origin. This reflects the few differences in the edaphic characteristics of these soils compared with the overall mean. The remaining $8.33 \%$ of the population comprised estate 7 , or group 3 , which was distant from the origin and showed clear differences in its edaphic traits compared to the other estates assessed.

However, despite the differences between groups, cup quality was similar across groups $(80.89,80.2$, and 79.6 for groups 1,2 and 3 ) and the overall mean $(80.5 \%)$. Therefore, this study could not establish the effect of certain soil variables on the physical and organoleptic quality of the coffee beverage. Accordingly, cup quality should be considered a multifactorial variable that depends on the genotype, environment, and the interaction between these two components (Suárez et al., 2015; Ramos and Criollo, 2017).

The PCA of the climatic variables allowed explaining $84.64 \%$ of the total variance in three large components. The first component accounted for $51.5 \%$ of the variability, the second component explained $17.62 \%$, and the third contributed to $15.44 \%$ of the variance (Table 4). Precipitation, photosynthetically active radiation (PAR), and solar radiation were most variable across the estates analyzed.

Table 4. Factor-trait correlations and contribution to variability of the first three principal components associated with climatic variables and coffee cup quality.

\begin{tabular}{lccc}
\hline \multirow{2}{*}{ Trait } & \multicolumn{3}{c}{ Factor } \\
\cline { 2 - 4 } & $\mathbf{1}$ & $\mathbf{2}$ & $\mathbf{3}$ \\
\hline Solar radiation-V1 & -0.92 & 0.10 & -0.01 \\
PAR-V2 & -0.94 & 0.22 & 0.09 \\
Relative humidity-V3 & 0.40 & -0.54 & -0.61 \\
Temperature-V4 & -0.83 & -0.31 & 0.22 \\
Precipitation-V5 & -0.39 & 0.38 & -0.77 \\
Temperature amplitude-V6 & -0.87 & -0.12 & -0.23 \\
Cup quality-V7 & -0.37 & -0.79 & 0.02 \\
\hline Eigenvalue & 3.613 & 1.23 & 1.00 \\
PV (\%) & 51.58 & 17.62 & 15.44 \\
CPV (\%) & 51.58 & 69.28 & 84.64 \\
\hline
\end{tabular}

$\mathrm{PV}=$ percentage of the variance; $\mathrm{CPV}=$ cumulative percentage of the variance.

The first component mainly included: solar radiation, PAR, temperature, and temperature amplitude with $\mathrm{CF}$ between 0.83 and 0.94 . Similarly, component 2 comprised the variables 
relative humidity $(-0.54)$ and cup quality score $(-0.79)$. Lastly, relative humidity and precipitation were determinant variables of component 3 , with CF of -0.61 and -0.77 , respectively.

The classification analyses allowed identifying three groups. The first group encompassed estates $1,2,11$ and 12 that represent $33.3 \%$ of the total estates. The first two coffee farm estates are located in the municipality of La Unión at elevations between 1501 and $1700 \mathrm{~m}$, while the last two are located in the municipality of La Florida at $\leq 1500 \mathrm{~m}$ and $>1700$ m.a.s.l., respectively. The second group included estates 3 and 4, which account for $16.6 \%$ of the estates and are located in La Unión between 1501 and 1700 m.a.s.l. The third group comprised estates $5,6,9,10,7$, and 8 , representing $50 \%$ of the estates (Figure 2).

The coffee farm estates of the first group are characterized by greater precipitation $(721.1 \mathrm{~mm})$ compared with the overall mean (572.88mm). Furthermore, other variables that showed higher values than the overall mean were thermal amplitude $\left(5.26^{\circ} \mathrm{C}\right)$ and PAR $(412.98 \mathrm{~nm})$. The cup quality score of the coffee produced in these lands was $79.92 \%$, while the overall mean was $80.5 \%$.
Group 2 (Figure 2) comprised farms that received higher solar radiation $\left(256.44 \mathrm{~W} / \mathrm{m}^{2}\right)$, greater PAR $(509.51 \mathrm{~nm})$, and showed greater diurnal and nocturnal temperature amplitude $\left(5.95^{\circ} \mathrm{C}\right)$ in comparison to the overall means $\left(202.77 \mathrm{~W} / \mathrm{m}^{2}\right.$, $401.06 \mathrm{~nm}$, and $4.86^{\circ} \mathrm{C}$, in the same order). The cup quality score of these farms was 82.85 .

The farms in group 3 were characterized by higher relative humidity (73.41\%) than the overall mean $(72.73 \%)$. Additionally, they showed lower temperature amplitude $\left(4.23^{\circ} \mathrm{C}\right)$, precipitation $(457.13 \mathrm{~mm})$, PAR $(356.96 \mathrm{~nm})$, solar radiation $\left(184.75 \mathrm{~W} / \mathrm{m}^{2}\right)$, and environmental temperature $\left(18.94^{\circ} \mathrm{C}\right)$ compared with the overall means $\left(4.86^{\circ} \mathrm{C}\right.$, $572.88 \mathrm{~mm}, 401.06 \mathrm{~nm}, 202.77 \mathrm{~W} / \mathrm{m}^{2}$, and $19.64^{\circ} \mathrm{C}$, respectively). Coffee cup quality (80.2) for this group was very similar to the overall mean (80.5).

Several studies found that the highest scores for the sensory attributes of the cup are obtained from shade-grown coffee at higher elevations. This demonstrates the need to adequately manage tree cover along with elevation (Suárez et al., 2015).

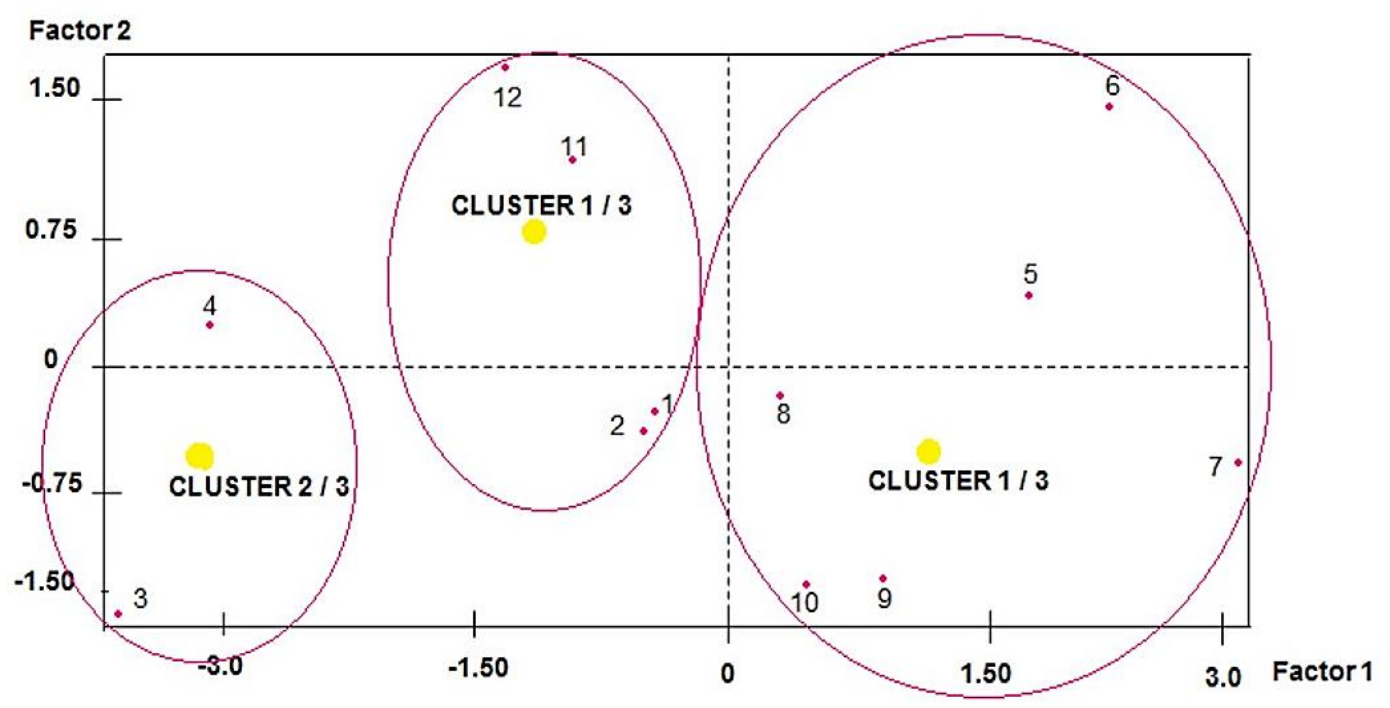

Figure 2. Distribution of the estates analyzed in the first two principal components based on the environmental factors and the three groups identified through the classification analysis. 
The effects of shade trees on coffee production are difficult to characterize since studies often omit important data or do not quantify them; for instance, intensity and quality of the radiation that reaches the tree canopy, daily and seasonal fluctuations in temperature and relative humidity, nutrition, and overlooked crop management conditions (DaMatta and Ramalho, 2006; DaMatta and Rodríguez, 2007). In this study, no tendency was observed regarding quality in response to the environments in ecotypes $220 \mathrm{~A}$ and $221 \mathrm{~A}$.

Coffee benefit comprises all the processes aimed to transform the coffee berry into dry parchment coffee without affecting its organoleptic, sanitary, and physical characteristics (Gómez, 2010). The analysis of variables associated with this process showed that $41.6 \%$ of the farms mix coffee from different harvest days before the fermentation process, and $50 \%$ select the coffee after washing. Furthermore, 75\% use a motorized coffee pulper, $16.6 \%$ use a mucilaginator, and the remaining farms use a manual pulper. After drying, only $16.6 \%$ of coffee producers obtain humidity between 10 and $12 \%$, while $83.3 \%$ package the coffee grain with more than $12 \%$ humidity. Low humidity contents provide the coffee grain with greater stability of its organoleptic characteristics; thus, better conserving its quality (Puerta-Quintero, 2006).

Regarding the $\mathrm{pH}$ of the fermenting mass, $75 \%$ of producers begin with a $\mathrm{pH}$ between 5.0 and 6.5. This data agrees with Córdoba-Castro and Guerrero-Fajardo (2016), who found an initial fermenting $\mathrm{pH}$ between 5.5 and 5.6 for Castillo variety. Puerta-Quintero (2013) reported an initial $\mathrm{pH}$ of 5.6 and indicates that these values depend on the maturity of the grain, the time between collection and pulping, and fruit manipulation. Moreover, $8.3 \%$ of the farms begin the process with a $\mathrm{pH}>6.5$, while $16.6 \%$ do not ferment the coffee grain. Additionally, $25 \%$ of the producers terminate the process when the $\mathrm{pH}$ is between 3.0 and 3.5 , while $58.3 \%$ end it at a $\mathrm{pH}>3.5$. According to Jackels and Jackels (2005), a final pH of 4.6 may be optimal to terminate the fermentation process without risking over-ferment of the grain.

During fermentation, the $\mathrm{pH}$ decreases due to the increased acidity of the mass. Generally, $\mathrm{pH}$ values between 3.7 and 4.1 for the fermented mucilage are adequate and safe to interrupt the fermentation process (Puerta-Quintero, 2012). Only 8.3\% of the producers achieved 'excellent' cup quality scores, $41.6 \%$ produced coffee with a 'very good' qualification, and $50 \%$ did not achieve a specialty coffee qualification due to scores below 80 points.

\section{CONCLUSIONS}

Coffee cup quality scores did not show an association with elevation. The highest score was achieved for coffee grown at $\leq 1500$ m.a.s.l. Low levels of association were found between the soil variables and cup quality; furthermore, $\mathrm{Fe}$ and $\mathrm{Cu}$ contents showed the highest association levels among the variables assessed.

The farms in La Unión showed the highest radiation, PAR, and thermal amplitude and conformed a group with the highest cup qualities. The characteristics associated with higher cup quality were found La Unión and Consacá in production units located at elevations $\leq 1500$ m.a.s.l.

\section{ACKNOWLEDGMENTS}

The authors express their gratitude to the Grupo de Investigación en Producción de Frutales Andinos of Universidad de Nariño and the project entitled "Research Evaluation of the effect of shade by different tree species on the agronomic behavior and quality of coffee, Consacá, Nariño, Occidente" funded by the SGR.

Conflict of interest: The authors declare that there is no conflict of interest. 


\section{BIBLIOGRAPHICAL REFERENCES}

Alvarado, A.; Puerta, G. (2002). La variedad Colombia y sus características de calidad física y taza. Avance Técnico No. 303. Chinchiná: CENICAFE. 4p. Recovered from https://biblioteca.cenicafe.org/ bitstream/10778/559/1/avt0303.pdf

Alvarado, A.; Posada, S.; Cortina, G. (2005). Castillo: Nueva variedad de café con resistencia a la roya. CENICAFE. Avance técnico 337. Recovered from https://www.cenicafe.org/es/publications/ avt0337.pdf

Alvarado, A. G.; Moreno, E.; Montoya, C.; Alarcón, R. 2009. Calidad física y en taza de los componentes de la variedad castillo ${ }^{\circledR}$ y sus derivadas regionales. Cenicafé. 60(3):210-228.

Aristizabal, A.; Duque, 0. (2006). Determinación de económicas de escalas en el proceso de beneficio del café en Colombia. Cenicafe. 57(1): 17-30.

Ávila, H.; García, S.; Rosas, J. (2015). Análisis de Componentes Principales, como herramienta para interrelaciones entre variables fisicoquímicas y biológicas en un ecosistema lentico de Guerrero, México. Revista Iberoamericana de Ciencias. 2(3): 43-53.

Castro, P.; Contreras, Y.; Laca, D.; Nakamatsu, K. (2004). Café de especialidad: alternativa para el sector cafetalero peruano. Recovered from http://jefas.esan.edu.pe/index.php/jefas/article/ view/166/157

Céspedes, E. (2012). Montaje del laboratorio de calidad de café en campus Majavita Universidad Libre seccional Socorro. Bucaramanga: Universidad Industrial de Santander. 75p.

Córdoba-Castro, N.; Guerrero-Fajardo, J. (2016). Caracterización de los procesos tradicionales de fermentación de café en el departamento de Nariño. Biotecnología en el Sector Agropecuario y Agroindustrial. 14(2): 75-83. doi: https://dx.doi. org/10.18684/BSAA(14)75-83

Cruz, J.; Rodríguez, W.; Suárez, J.; Ordoñez, C.; Vega, G. (2017). Minority compounds and sensory analysis evaluation of Coffea arabica var. Caturra cultivated in three different altitudinal ranges. Acta Agronómica. 66 (2): 221-227. doi: http://dx.doi.org/10.15446/ acag.v66n2.58126

DaMatta, F.; Ramalho, J. (2006). Impacts of drought and temperature stress on coffee physiology and production: a review. Braz. J. Plant Physiology. 18(1): 55-81.

DaMatta, F; Rodríguez, N. (2007). Producción sostenible de cafetales en sistemas agroforestales del Neo trópico: una visión agronómica y eco fisiológico. Agrono. Colomb. 25(1): 113-123.

Estrella, K.; Chaves, P. (2008). Plan de posicionamiento del café "Passion del express. Quito, Ecuador: Instituto de altos estudios nacionales. 142p.

Farfán, F. (2007). Cafés especiales. En: Sistemas de producción de café en Colombia. Chinchiná: Cenicafé. 309p.

Geromel, C.; Ferreira, L.; Davrieux, F.; Guyot, B.; Ribeyre, F.; Dos Santos, M.; Protasio, L.; Vaast, Ph.; Pot, D.; Leroy, T.; Androcioli Filho, A.; Esteves Vieira, L.; Mazzafera, P.; Marraccini, P. (2008). Effects of shade on the development and sugar metabolism of coffee (Coffea arabica L.) fruits. Plant Physiology and Biochemistry. 46: 569-579. doi: https://doi. org/10.1016/j.plaphy.2008.02.006

Gómez, G. (2010). Cultivo y beneficio del café. Revista de Geografía Agrícola. 45:105-193.

Gómez, L.; Caballero, A.; Baldión, J. (1991). Ecotopos cafeteros de Colombia. Santa Fe de Bogotá: Federación Nacional de Cafeteros de Colombia, Cenicafé - Agroclimatología, División de Desarrollo Social. 138p.

Jackels, S.; Jackels, C. (2005). Characterization of the coffee mucilage fermentation process using chemical indicators: A field study in Nicaragua. Journal of Food Science. 70(5): c321-c325. doi: https://doi. org/10.1111/j.1365-2621.2005.tb09960.x

Lara, L.; Vaast, P. (2007). Effects of altitude, shade, yield and fertilization on coffee quality (Coffea arabica L. var. Caturra) produced in agroforestry systems of the Northern Central Zones of Nicaragua. Journal of Food Science. 68(7): 2356-2361. 
Marín, L.; Arcila, P.; Montoya, R.; Oliveros, T. (2003). Cambios físicos y químicos durante la maduración del fruto de café (Coffea arabica L. var. Colombia). Revista Cenicafé. 54(3): 2008-225.

Montilla, J., Arcila, J., Aristizabal, M., Montoya, E., Puerta, G., Oliveros, C.; Cadena, G. (2008). Caracterización de algunas propiedades físicas y factores de conversión del café durante el proceso de beneficio húmedo tradicional. Revista Cenicafé. 59(2):120-142.

Montoya, R. (1999). Caracterización de la infestación del café por la broca y efecto del daño en la calidad de bebida. CENICAFE. 50(4): 245-258.

Moreno, A. (2007). Fundamentos sobre sistemas de producción. En: Arcila, J.; Farfán, F.; Moreno, A.; Salazar, L.; Hincapie, E. Sistemas de producción de café en Colombia. (15 - 20p). Chinchiná: Cenicafé. $309 \mathrm{p}$.

Orozco, N.; Guacas, A.; Bacca, T. (2011). Caracterización de fincas cafeteras por calidad de la bebida y algunas condiciones ambientales y agronómicas. Revista de Ciencias Agrícolas. 28(2): 9-17.

Otzen, T.; Manterola, C. (2017). Técnicas de muestreo sobre una población a estudio. Int. J. Morphol. 35(1): 227-232.

Puerta-Quintero, G. (2000). Influencia de los granos de café cosechados verdes, en la calidad física y organoléptica de la bebida. Cenicafé. 51(2): 136-150.

Puerta-Quintero, G. (2000a). Factores relacionados con la calidad de bebida del café. Chinchina: CENICAFE. 45p.

Puerta-Quintero, G. (2006). La humedad controlada del grano preserva la calidad del café. Avance técnico No. 352. Chinchiná: CENICAFE. 8p.

Puerta-Quintero, G. (2012). Factores, procesos y controles en la fermentación del café. Avances técnicos 422. Chinchiná: CENICAFE. 12p.

Puerta-Quintero, G. (2013). Cinética química de la fermentación del mucílago de café a temperatura ambiente. Revista Cenicafé. 64(1): 42-59.
Puerta-Quintero, G.; González, F.; Correa, A.; Álvarez, I.; Ardila, J.; Girón, 0.; Ramírez, C.; Baute, J.; Sánchez, P.; Santamaría, M.; Montoya, D. (2016). Diagnóstico regional de la calidad de la bebida de café de Colombia, según altitud, suelos y buenas prácticas de beneficio. Revista Cenicafé. 67(2): 15-51.

Ramos, L.; Criollo, H. (2017). Calidad física y sensorial de Coffea arábica L. variedad Colombia, perfil Nespresso AAA, Unión Nariño. Revista de Ciencias Agrícolas. 34(2): 83 - 97. doi: https://doi. org/10.22267/rcia.173402.74

Raynolds, L. (2009). Mainstreaming fair trade coffee: from partnership to traceability. World Development. 37(6):1083 - 1093. doi: 10.1016/j. worlddev.2008.10.001.

Rosas, J.; Escamilla, E.; Ruiz, 0. (2008). Relación de los nutrimentos del suelo con las características físicas y sensoriales del café orgánico. Terra latinoamericana. 26: 375- 384.

Sepúlveda, W.; Maza, M.; Mantecón, A. (2013). Information demanded by consumers: New issues in voluntary beef labeling. Acta Alimentaria. 42(2):3 - 10. doi:10.1556/AAlim.42.2013.2.2

Specialty Coffee Association of America- SCAA. (2015). SCAA protocols, Cupping Specialty Coffee. Recovered from https://www.scaa.org/PDF/ resources/cupping-protocols.pdf

Suárez, J.; Rodríguez, E.; Duran, E. (2015). Efecto de las condiciones de cultivo, las características químicas del suelo y el manejo de grano en los atributos sensoriales de café (Coffea arabica L.) en taza. Acta Agronómica. 64(4): 342-348. doi: http://dx.doi. org/10.15446/acag.v64n4.44641

Ward, J. (1963). Hierarchical grouping to optimize an objective function. Journal of the American Statistical Association. 58 (301): 236-244. Recovered from http://www.jstor.org/stable/2282967 